UNIVERSIDADE DE SÃO PAULO

ESCOLA DE ENFERMAGEM

RICARDO HENRIQUE SOARES

DECISÕES JUDICIAIS NO CAMPO DA SAÚDE MENTAL

SÃO PAULO

2012 
RICARDO HENRIQUE SOARES

\section{DECISÕES JUDICIAIS NO CAMPO DA SAÚDE MENTAL}

Dissertação apresentada à Escola de Enfermagem da Universidade de São Paulo para obtenção do título de Mestre em Ciências.

Área de concentração: Cuidado em Saúde

Orientadora: Prof ${ }^{\mathrm{a}}$. Dr ${ }^{\mathrm{a}}$. Márcia Aparecida Ferreira de Oliveira

\section{SÃO PAULO}


AUTORIZO A REPRODUÇÃO E DIVULGAÇÃO TOTAL OU PARCIAL DESTE TRABALHO, POR QUALQUER MEIO CONVENCIONAL OU ELETRÔNICO, PARA FINS DE ESTUDO E PESQUISA, DESDE QUE CITADA A FONTE.

Assinatura:

Data:

Catalogação na Publicação (CIP)

Biblioteca "Wanda de Aguiar Horta"

Escola de Enfermagem da Universidade de São Paulo

Soares, Ricardo Henrique

Decisões judiciais no campo da saúde mental / Ricardo

Henrique Soares. -- São Paulo, 2012.

$115 \mathrm{p}$.

Dissertação (Mestrado) - Escola de Enfermagem da Universidade de São Paulo.

Orientadora: Prof ${ }^{a}$ Dr $^{a}$ Márcia Aparecida Ferreira de Oliveira

Área de concentração: Cuidado em Saúde

1. Adolescentes 2. Reforma psiquiátrica 3. Territorialidade 4. Saúde mental 5. Decisão judicial I. Título. 
Nome: Ricardo Henrique Soares

Título: Decisões judiciais no campo da saúde mental

Dissertação apresentada à Escola de Enfermagem da Universidade de São Paulo para obtenção do título de Mestre em Ciências.

Aprovado em:

\section{Banca Examinadora}

Prof. Dr.

Instituição:

Julgamento:

Assinatura:

Prof. Dr.

Instituição:

Julgamento:

Assinatura:

Prof. Dr.

Instituição:

Julgamento:

Assinatura: 


\section{AGRADECIMENTOS}

É neste espaço dedicado aos agradecimentos que posso enfatizar e reconhecer a confiança, a esperança e o suporte depositados pelas pessoas que compuseram o pano de fundo deste estudo. Pano de fundo que dá luz à figura, permitindo-a aparecer e brilhar. Com seu brilho, a figura, destacada do fundo, deve reivindicar que os olhares se detenham também para a origem de sua luz, evitando a alienação e a pateticidade de se pretender uma unidade paralela e separada de sua totalidade.

Até o último momento e desde o seu início, como na vida, a composição deste estudo manifestou seu caráter processual: transitoriedade, parcialidade e transformação, jamais podendo ser tido como completo e perene, salvo pela materialização instrumental de seu registro.

Sendo processo, este estudo não começa nem termina aqui, ele passa, flui. E esta passagem deve ser apresentada não como autorreconhecimento, mas como uma consequência condicionada e efetivada por um conjunto de pessoas, anônimas e conhecidas.

É importante também salientar que, ao contrário do que a estilística textual poderia nos levar a supor a respeito da construção deste estudo como um texto discursivo correto, linear e "limpo", na realidade trata-se de um discurso montado, pois fraturado, e ajustado a diversos obstáculos e desafios que se impuseram num percurso muitas vezes contraditório e de destino desconhecido, mas que de alguma forma foram superados.

Sem identificar a qualidade especial e a contribuição de cada uma das pessoas que compreenderam o pano de fundo deste trabalho e que detêm minha mais profunda admiração e afeição, sob pena de cometer injustiças pelo reducionismo e ou pela ênfase em determinados aspectos, vez que o potencial de cada uma delas é inesgotável, enumero, a título exemplificativo e sem uma ordem de preferência (em ordem alfabética), as pessoas que ora presto meus sinceros agradecimentos, sem as quais este estudo não se realizaria: Alice Soares Rebouças, Aurélio Henriques Soares, Aurélio Henrique Soares Júnior, Cíntia B. Ribeiro, Dário F. Sousa Neto, Egberto de Almeida Penido, Isabella C. Ribeiro, José A. Santos, Maria Antônia Soares, Maria de Fátima Soares, Márcia Aparecida Ferreira de Oliveira, Nelson Antônio de Castro Ribeiro. 
Soares RH. Decisões judiciais no campo da saúde mental. [Dissertação]. São Paulo: Escola de Enfermagem, Universidade de São Paulo; 2012.

\section{RESUMO}

O presente estudo é resultado de uma pesquisa documental realizada nos autos dos processos das Varas Especiais da Infância e da Juventude da Comarca de São Paulo que continham decisões judiciais determinando o encaminhamento de crianças $\mathrm{e}$ adolescentes usuários de substâncias psicoativas para tratamento no campo da saúde mental, com o objetivo de conhecer, compreender e analisar os discursos que sustentam as decisões do Judiciário no campo da saúde mental quanto ao modelo assistencial adotado no caso concreto, respondendo à questão: as decisões do Poder Judiciário no campo da saúde mental estão orientadas para o modelo de assistência psiquiátrica tradicional ou para o modelo de assistência proposto pela reforma psiquiátrica? A análise documental se valeu da técnica de Análise do Discurso, cujos resultados foram discutidos à luz do referencial teórico do materialismo histórico-dialético, tendo a ideologia como categoria de análise. A partir da constatação da contradição estabelecida entre o tratamento em saúde mental de atenção psicossocial e as medidas socioeducativas de internação e semiliberdade, referente à precarização da territorialidade dos adolescentes, o estudo revelou duas condições essenciais para a determinação do respectivo paradigma teórico-assistencial do campo da saúde mental adotado pelo Judiciário, quais sejam, a avaliação da esfera territorial dos adolescentes e o conhecimento do específico dispositivo de saúde mental indicado para o tratamento dos jovens, condições que propiciaram a identificação de que uma das amostras encontra abrigo no referencial da reforma psiquiátrica.

Descritores: adolescente em conflito com a lei; reforma psiquiátrica; territorialidade. 
Soares RH. Court's decisions in the mental health field. [Dissertation]. São Paulo: Escola de Enfermagem, Universidade de São Paulo; 2012.

\begin{abstract}
This study is the result of documental research performed on the proceedings of the Special Courts for Children and Youth of the district of São Paulo containing judiciary decisions on the forwarding of children and adolescent users of psychoactive substances for treatment in the mental health field with the objective of knowing, comprehending, and analyzing the discourses that support the court's decisions in the mental health field relative to care model chosen, answering the following question: are the court's decisions in the mental health field oriented by the model of traditional psychiatric care or by the model proposed by the psychiatric reform? The documentary analysis was made using the technique of discourse analysis, whose results were based on the theoretical-methodological system of Historical and Dialectical Materialism, having ideology as its category of analysis. From the contradiction between mental health treatment and the institutionalization measures of the Special Courts for Children and Youth concerning the territorial precariousness of adolescents, the study revealed two essential conditions to determine which theoretical paradigm is chosen by the judiciary: the evaluation of territorial sphere of adolescents and the knowledge of the particular mental health service for the treatment of adolescents; conditions that helped identify among the samples, one that belongs to psychiatric reform.
\end{abstract}

Descriptors: adolescent in conflict with the law; psychiatric reform; territoriality. 


\section{SUMÁRIO}

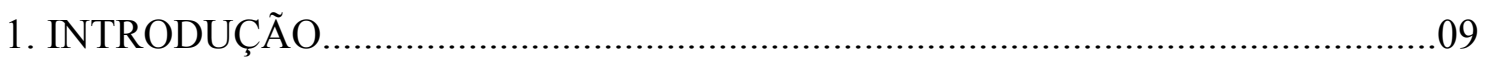

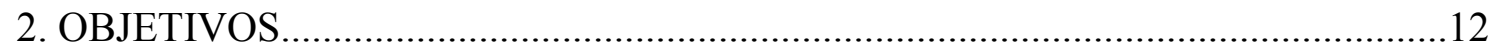

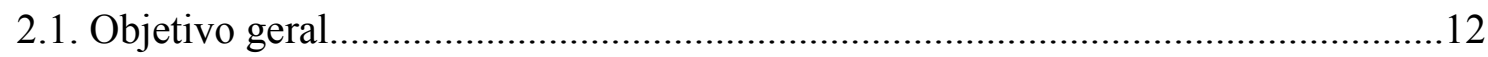

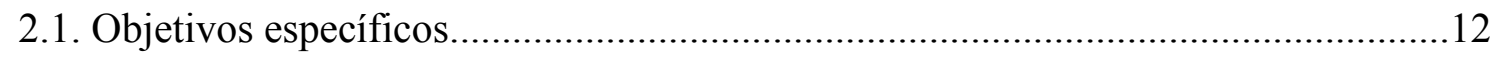

3. CAPÍTULO I - Modelos assistências em saúde mental...........................................13

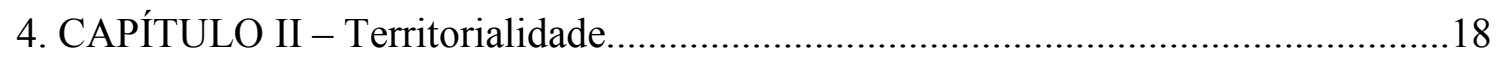

5. CAPÍTULO III - Direitos da criança e do adolescente...........................................21

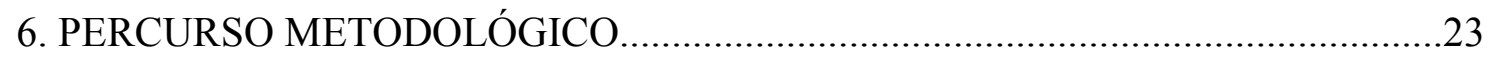

6.1. Referencial teórico-filosófico do materialismo histórico-dialético.........................23

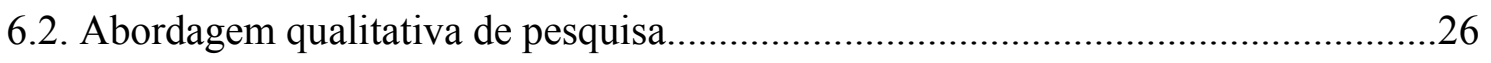

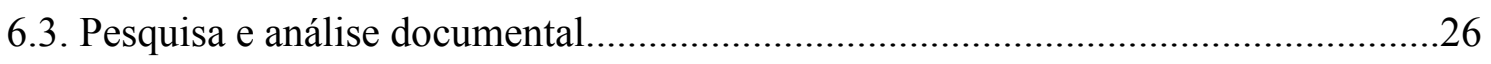

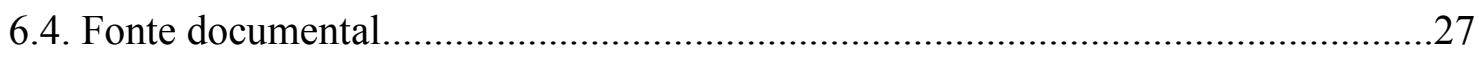

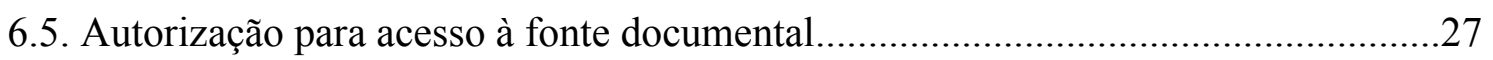

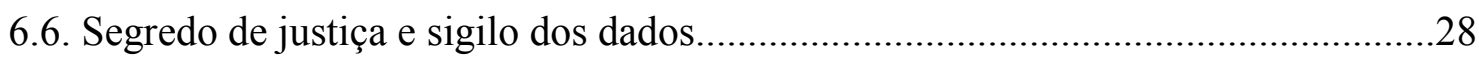

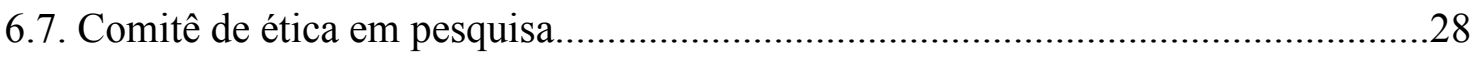

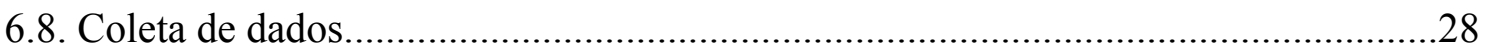

6.9. Análise do discurso como estratégia de analise documental................................29

6.10. Observações sobre a apresentação e análise das amostras documentais..................31

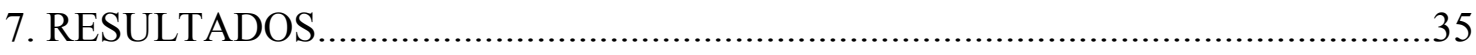

7.1. Caracterização do perfil socioeconômico dos adolescentes.....................................35

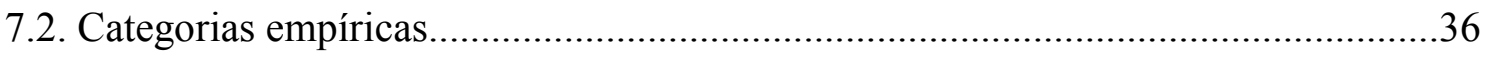

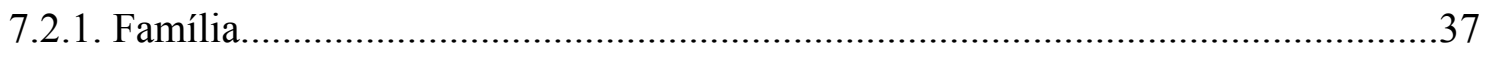

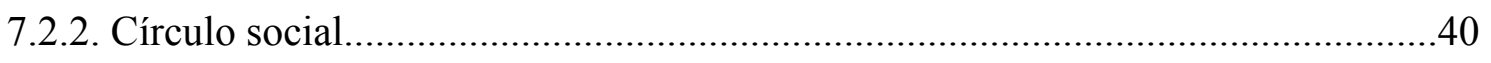

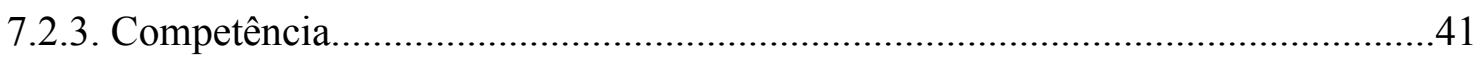


7.3. Decisões judiciais de encaminhamento aos serviços de saúde mental .43

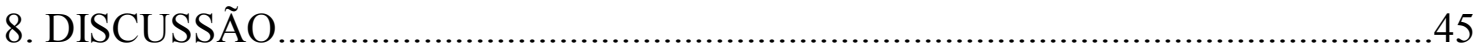

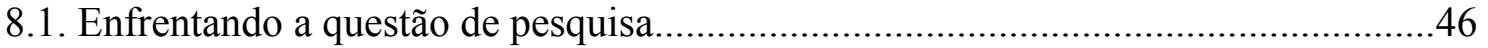

8.2. Leis e categorias do materialismo histórico-dialético...........................................51

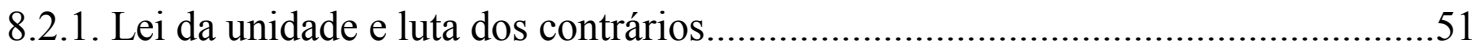

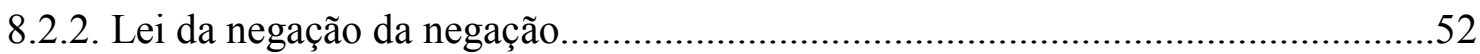

8.2.3. Lei da passagem de transformações quantitativas a qualitativas...........................52

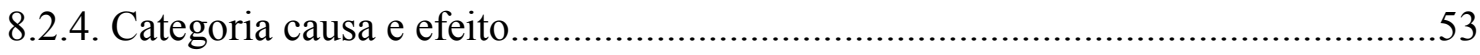

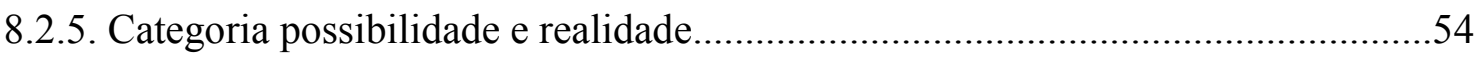

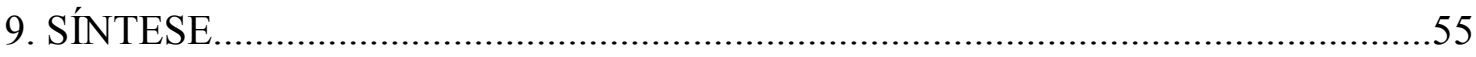

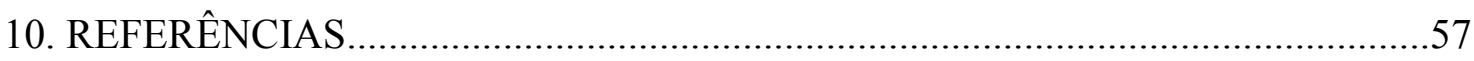

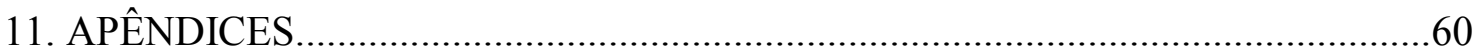

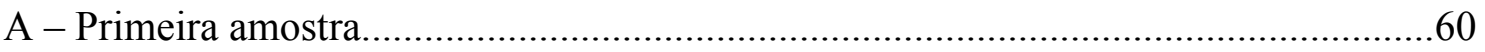

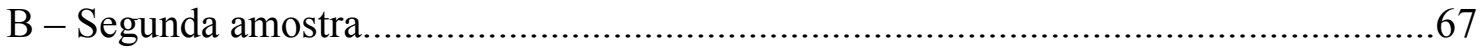

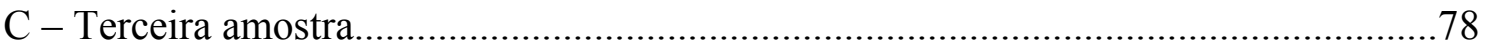

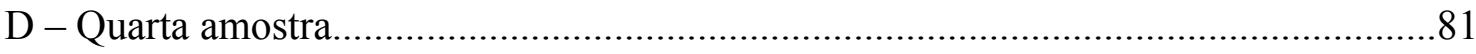

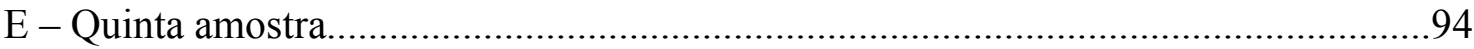

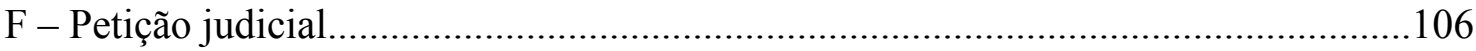

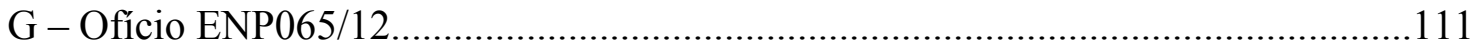

12. ANEXOS

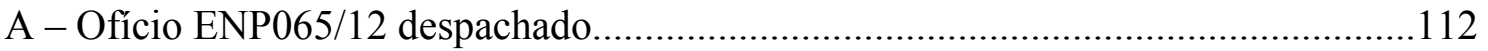

B - Parecer do Comité de Ética em Pesquisa..............................................................113 


\section{INTRODUÇÃO}

Face ao princípio da inafastabilidade do controle jurisdicional ${ }^{1}$, o Poder Judiciário manifesta-se num universo diversificado de demandas, envolvendo variados campos do conhecimento, dentre os quais o da saúde mental. Sua atuação neste campo do conhecimento é fundamental para a manutenção das garantias e dos direitos individuais, especialmente das pessoas acometidas de sofrimento mental.

A atuação do Poder Judiciário no campo da saúde mental merece nossa atenção em função do processo de transformação que as teorias e técnicas assistenciais em saúde mental vêm sofrendo nas últimas décadas. Inscrito num contexto histórico-político internacional de reivindicações em favor da humanização do cuidado em saúde mental e de inclusão de modelos assistenciais alternativos aos tratamentos psiquiátricos asilares, esse processo de transformação conceitual e assistencial em saúde mental é representado pelo movimento de Reforma Psiquiátrica.

Em termos de modelo de atenção em saúde mental, o movimento de Reforma Psiquiátrica privilegia a adoção de tecnologias diversas das de caráter manicomial, propondo um modelo de assistência baseado em dispositivos de rede comunitária de atenção psicossocial ${ }^{2}$, em detrimento do modelo psiquiátrico tradicional, centralizado no tratamento hospitalar.

O movimento de Reforma Psiquiátrica se expressa formalmente no Brasil através da Política Nacional de Saúde Mental $^{3}$ e pela instituição da lei 10.216/2001 ${ }^{4}$ no ordenamento jurídico vigente. A Política Nacional de Saúde Mental visa à consolidação de um modelo de atenção em saúde mental de base comunitária como substituto do modelo hospitalar especializado e se apoia na Lei 10.216/2001. Este diploma legal, conhecido como Lei da Reforma Psiquiátrica, caracteriza-se principalmente por assegurar os direitos das pessoas com transtornos mentais sem qualquer forma de discriminação e reorienta o modelo de assistência em saúde mental para serviços, preferencialmente, extra-hospitalares. Em nível estadual, a legislação de São Paulo

\footnotetext{
${ }^{1}$ Constituição Federal, art. $5^{\circ}$, XXXV: "a lei não excluirá da apreciação do Poder Judiciário lesão ou ameaça a direito" (Brasil, 2007)

${ }^{2}$ Termo ligado ao caráter não exclusivamente médico das práticas assistenciais em saúde mental.

${ }^{3}$ Conferência Regional de Reforma dos Serviços de Saúde Mental (2005).

${ }^{4}$ Lei 10.216/2001 dispõe sobre a proteção e os direitos das pessoas portadoras de transtornos mentais e redireciona o modelo assistencial em saúde mental (Brasil, 2001).
} 
promove o movimento de Reforma Psiquiátrica, sobretudo através do Código de Saúde do Estado (Lei Complementar Estadual 791/1995 ${ }^{5}$ ), referendado pela Lei 10.241/1999 ${ }^{6}$, estabelecendo a "adoção e o desenvolvimento de ações predominantemente extrahospitalares, na forma de programas de apoio à desospitalização", no âmbito de tratamentos em saúde mental.

Esse contexto de transformações teórico-técnicas promovidas pelo movimento de reforma psiquiátrica alimenta o debate sobre as medidas no campo da saúde mental empreendidas pelos poderes públicos, notadamente em face de crianças e adolescentes usuários de substâncias psicoativas. Dentre as providências que os poderes públicos vêm tomando com relação a esses usuários de substâncias psicoativas e que vivem em situação de rua, destacam-se medidas que visam à internação psiquiátrica compulsória dessas pessoas, a despeito das referidas disposições legais atinentes ao caráter excepcional dessa modalidade terapêutica.

Em alguns casos, a fim de viabilizar esse expediente, os poderes públicos valemse da via judicial, requerendo a intervenção do Poder Judiciário na decretação de internações psiquiátricas compulsórias, como no exemplo da cidade do Rio de Janeiro, na qual, "desde 30 de maio [de 2011], após entendimentos com o Ministério Público e a Justiça, crianças e adolescentes usuários de drogas, quando recolhidos das ruas do Rio, são obrigados a permanecer em tratamento" (Folha de São Paulo, 2011) ${ }^{7}$.

No mesmo sentido, a "Prefeitura de São Paulo quer retirar das ruas, à força se for preciso, usuários de drogas que recusem tratamento (...) Prefeitura de SP procura consenso jurídico para adotar a medida" ${ }^{8}$ (Folha de São Paulo, 2011), havendo projeto do Tribunal de Justiça do Estado para "implantar um posto volante na cracolândia, região central da capital, para tentar acabar com a multidão de crianças e adolescentes envolvidos com drogas" 9 (Folha de São Paulo, 2011).

Com efeito, é nesse processo de mudanças das práticas e saberes do campo da saúde mental que o Poder Judiciário é movido a manifestar-se, podendo produzir com suas decisões efeitos sobre o modelo de cuidado em saúde mental a ser adotado no caso

\footnotetext{
${ }^{5}$ Lei Complementar Estadual 791/1995, art. 33, incisos I a VI (São Paulo, 1995).

${ }^{6}$ Lei 10.241/1999, art. $2^{\circ}, \S 2^{\circ}$ (São Paulo, 1999).

7"Menor de 18 é obrigado a se tratar no Rio" (Folha de São Paulo, 2011)

"Kassab quer tirar à força viciado das ruas" (Folha de são Paulo, 2011).

"Na rua, juiz vai avaliar menores da cracolândia" (Folha de são Paulo, 2011).
} 
concreto: o modelo psiquiátrico tradicional ou o modelo proposto pela reforma psiquiátrica.

É no cerne do processo de mudanças teórico-práticas no cuidado em saúde mental e no contexto de implantação de políticas públicas frente à condição de pessoas usuárias de substâncias psicoativas que o presente estudo se propôs analisar as decisões do Poder Judiciário no campo da saúde mental, situando a problemática de análise dessas decisões ao âmbito de crianças e adolescentes usuários de substâncias psicoativas, especialmente com relação à orientação teórico-técnica do campo da saúde mental adotada pelo Judiciário, com o objetivo de responder a questão: as decisões do Poder Judiciário no campo da saúde mental estão orientadas para o modelo de assistência psiquiátrica tradicional ou para o modelo de assistência proposto pela reforma psiquiátrica?

A relevância em pesquisar a orientação assistencial em que se dirigem as decisões do Poder Judiciário no campo da saúde mental reside em revelar sua tendência e alinhamento tecnológico em saúde mental, bem como conhecer a qualidade de sua atuação no processo mesmo da reforma psiquiátrica, examinando seu nível de apropriação dos referenciais e princípios da reforma psiquiátrica brasileira. 


\section{OBJETIVOS}

\subsection{Objetivo Geral}

Conhecer, compreender e analisar os discursos que sustentam as decisões do Poder Judiciário da Comarca de São Paulo no campo da saúde mental quanto ao modelo assistencial adotado no caso concreto.

\subsection{Objetivos Específicos}

2.2.1. Caracterizar e analisar os autos dos processos judiciais das Varas Especiais da Infância e da Juventude da Comarca de São Paulo que contenham decisões determinando o encaminhamento de crianças e adolescentes usuários de substâncias psicoativas para tratamento no campo da saúde mental quanto ao modelo assistencial adotado no caso concreto;

2.2.2. Descrever e discutir o perfil socioeconômico das crianças e dos adolescentes usuários de substâncias psicoativas que são submetidos pelas Varas Especiais da Infância e da Juventude da Comarca de São Paulo a tratamentos no campo da saúde mental;

2.2.3. Apreender e discutir as ideias, significados e representações contidas nos discursos judiciais das Varas Especiais da Infância e da Juventude da Comarca de São Paulo que sustentam as decisões que determinam o tratamento de crianças e adolescentes usuários de substâncias psicoativas no campo da saúde mental. 


\section{CAPÍTULO I - Modelos assistências em saúde mental}

Ao longo deste estudo, em função dos objetivos propostos e da própria questão de pesquisa, faremos inúmeras referências a dois modelos teórico-assistenciais do campo da saúde mental: de um lado o modelo psiquiátrico clássico ou tradicional e, de outro, o modelo proposto pelo movimento de reforma psiquiátrica, também conhecido como modelo de atenção psicossocial ou, ainda, como serviço de saúde mental em rede comunitária.

Antes de estabelecermos uma comparação entre as características desses paradigmas da psiquiatria tradicional e da reforma psiquiátrica, abordaremos de forma breve algumas considerações históricas sobre o desenvolvimento dos saberes e das práticas relativas às pessoas em sofrimento mental.

Os hospitais, antes de se tornarem instituições médicas por excelência, funcionavam como albergues para pobres, mendigos, desabrigados, doentes etc. e eram sustentados por instituições filantrópicas que desenvolviam este trabalho a título de caridade. Essas hospedarias (hospitais), que recebiam intervenções médicas de forma sazonal, esporádica e pontual, passaram a ser controladas pela corporação médica a partir da assunção do hospital como lugar destinado ao tratamento das doenças, incluindo as alienações, como eram nomeados os problemas das pessoas acometidas de sofrimento mental, a partir do entendimento da então nascida psiquiatria, proposta por Philippe Pinel, no final do século XVIII. Com a aplicação do método teórico de Pinel: o tratamento moral e o isolamento dos alienados das perturbações provenientes do seio social, o hospital converteu-se no recurso terapêutico primordial para o controle das paixões desregradas e para a recuperação da razão dos alienados. Ou seja, a hospitalização dos pacientes era condição sine qua non para a aplicação e o desenvolvimento terapêutico (Amarante, 2007).

As críticas ao método psiquiátrico de clausura hospitalar dos pacientes, aliada às denúncias de violência, maus-tratos, precariedade da assistência e desrespeito à dignidade humana aparecem com maior intensidade no período do pós-guerra, numa associação entre as condições dos manicômios e dos campos de concentração nazistas. Esse processo crítico desencadeou no desenvolvimento de reformas no âmbito da psiquiatria, as quais, segundo Amarante (2007), podem ser classificadas em dois grupos, 
além de um terceiro grupo que o autor não identifica como reformador, mas como promotor de um rompimento com o saber e com as práticas psiquiátricas clássicas.

O primeiro grupo procedeu a uma reforma de gestão do hospital, o qual ainda continuava sendo o local adequado para o tratamento das chamadas doenças mentais. As mudanças na gestão da instituição propunham a organização de reuniões grupais a serem realizadas no hospital com a participação dos profissionais, dos pacientes e de seus familiares, visando à democratização do espaço hospitalar e da horizontalização das relações. Essas experiências, desenvolvidas na Inglaterra, introduziram o termo psicossocial e foram denominadas de Comunidades Terapêuticas. Ainda nesse mesmo grupo, são observadas reformas na psiquiatria francesa, que adotava a chamada Psicoterapia Institucional. Essa modalidade também manteve o hospital psiquiátrico como base central para o tratamento das "doenças mentais" com a diferença de propor a ampliação dos referenciais teóricos alusivos ao sofrimento mental, notadamente a escuta clínica, bem como propôs a valorização do acolhimento dos pacientes e a humanização da instituição hospitalar.

O segundo grupo de reformas surgiu no final dos anos 50 na França e nos Estados Unidos, respectivamente, como Psiquiatria de Setor e Psiquiatria Preventiva ou Saúde Mental Comunitária. A chamada Psiquiatria de Setor criou Centros de Saúde Mental de atendimento multiprofissional, distribuídos em setores regionais da população como forma de oferecer alternativas extra-hospitalares aos pacientes desinternados. Essa setorização também atingia o próprio hospital psiquiátrico, onde pacientes eram internados em enfermarias correspondentes aos seus respectivos setores regionais, de modo que além de existir a possibilidade de se identificarem pelos aspectos comuns à região, os pacientes poderiam se beneficiar do contato com os visitantes residentes no seu setor regional.

As reformas ocorridas nos Estados Unidos pela chamada Psiquiatria Preventiva ou Saúde Mental Comunitária, consistiram no redirecionamento da política de assistência psiquiátrica do país, dividindo-se em prevenção primária, secundária e terciária. A prevenção primária buscava intervir nas condições determinantes da "doença mental" e trabalhava com dois conceitos para essa intervenção: crise e desvio. As crises eram entendidas como consequências de questões evolutivas (de mudanças no desenvolvimento normal) e acidentais (decorrentes de traumas emocionais), enquanto que o desvio era compreendido como resultante de comportamentos desviantes da 
norma; a prevenção secundária visava ao estabelecimento do diagnóstico e do tratamento precoce das "doenças mentais"; e a prevenção terciária preconizava a readaptação do paciente. Nesse contexto surgiu a ideia de desinstitucionalização, tida como processo de redução do período de hospitalização e diminuição do próprio ingresso de pacientes nos hospitais através do encaminhamento para centros de saúde mental, leitos em hospitais gerais, abrigos etc.

O terceiro grupo, que surge na esteira das reformas psiquiátricas, mas que Amarante (2007) não classifica como reformador pela sua proposta de rompimento com o paradigma da psiquiatria tradicional é composto pela Antipsiquiatria e pela Psiquiatria Democrática.

A Antipsiquiatria, surgida na Inglaterra e defendida por Laing e Cooper no final da década de 50, afirma que o hospital psiquiátrico reproduz e radicaliza a opressão social e que o método da psiquiatria, baseado nas ciências naturais, é equivocado, de modo que o próprio conceito de doença mental deve ser rejeitado e, por conseguinte, as suas respectivas propostas terapêuticas. Já a Psiquiatria Democrática, desenvolvida na Itália e idealizada por Basaglia na década de 60, nega a psiquiatria enquanto ideologia e critica a instituição manicomial em todos os seus aspectos (hospital psiquiátrico, saberes e práticas psiquiátricas, legislação que dá suporte às ações psiquiátricas etc.), propondo a desconstrução das instituições manicomiais. Em substituição aos hospitais psiquiátricos, a Psiquiatria Democrática Italiana criou centros de saúde mental (diferentes dos dispositivos americanos porque não eram referidos aos hospitais psiquiátricos), cooperativas de trabalho, residências para ex-internos, etc.

O movimento de reforma psiquiátrica no Brasil, na esteira dos movimentos da reforma sanitária e da redemocratização do país, apoiado por usuários, familiares, associações, sindicatos, igrejas, partidos políticos, pelo Movimento de Trabalhadores da Saúde Mental (MTSM), pelo Movimento Nacional da Luta Antimanicomial, implantou os primeiros serviços de saúde mental e de atenção psicossocial no final da década de 80, no município de Santos, no Estado de São Paulo (Amarante, 1995).

A expressão formal do movimento de reforma psiquiátrica no Brasil é consubstanciada pela da Política Nacional de Saúde Mental ${ }^{10}$ e pela lei 10.216/2001 ${ }^{11}$.

\footnotetext{
${ }^{10}$ Conferência Regional de Reforma dos Serviços de Saúde Mental (2005).

${ }^{11}$ Lei 10.216/2001 dispõe sobre a proteção e os direitos das pessoas portadoras de transtornos mentais e redireciona o modelo assistencial em saúde mental (Brasil, 2001).
} 
A Política Nacional de Saúde Mental prioriza a substituição do modelo assistencial centralizado no hospital por um modelo de atenção psicossocial de base comunitária. A Lei 10.216/2001, conhecida como Lei da Reforma Psiquiátrica, baliza a política nacional, assegurando os direitos das pessoas em sofrimento mental e reorientando o modelo de assistência em saúde mental, privilegiando serviços de natureza extrahospitalares. No mesmo sentido, a legislação do Estado de São Paulo promove a reforma psiquiátrica no Código de Saúde do Estado $^{12}$ e na Lei 10.241/1999 ${ }^{13}$, estabelecendo a "adoção e o desenvolvimento de ações predominantemente extrahospitalares, na forma de programas de apoio à desospitalização", na esfera de assistência em saúde mental.

Comparando as características dos paradigmas da psiquiatria tradicional e da reforma psiquiátrica, podemos observar que, enquanto a psiquiatria clássica trata da relação entre o médico e o paciente (doença), a atenção psicossocial de saúde mental trata de uma rede de relações entre sujeitos: cuidadores (assistentes sociais, médicos, enfermeiros, psicólogos, terapeutas ocupacionais, músicos, artistas plásticos, artesãos etc.) e sujeitos que vivem a experiência do sofrimento mental (usuários e familiares). A psiquiatria tradicional é centralizada no tratamento das doenças, enquanto que a atenção psicossocial é centralizada na pessoa, fato que amplia o campo da saúde mental e os serviços se constituem como dispositivos de trocas sociais.

Outra característica fundamental que diferencia os paradigmas da psiquiatria clássica e do serviço de saúde mental e atenção psicossocial se refere ao trabalho de base territorial. A psiquiatria tradicional não desenvolve o serviço em rede territorial, restringindo o serviço na sede da instituição. Para a atenção psicossocial, o serviço de base territorial é imprescindível e visa a desenvolver ao máximo as relações entre os usuários e seus familiares com os recursos existentes na comunidade, criando alianças sociais com diversos setores. Ou seja, o serviço de saúde mental em rede se vale da intersetorialidade como forma de compor uma articulação e cooperação simultânea entre diversos seguimentos:

- da própria rede de atenção à saúde mental: Centros de Atenção Psicossocial (CAPS), Serviços Residenciais Terapêuticos (SRT), unidades psiquiátricas em hospitais gerais, Centros de Convivência e Cultura, Cooperativas Sociais etc.

\footnotetext{
${ }^{12}$ Lei Complementar Estadual 791/1995, art. 33, incisos I a VI (São Paulo, 1995).

${ }^{13}$ Lei 10.241/1999, art. 2o, § 2ํ (São Paulo, 1999).
} 
- das áreas de saúde em geral: Estratégia Saúde da Família, Unidades Básicas de Saúde (UBS), hospitais gerais e especializados etc.

- das instituições públicas: escolas, Defensoria Pública, Ministério Público, Previdência Social, Poder Judiciário etc.

- da sociedade civil: associações de bairro, grupos religiosos, organizações nãogovernamentais, cooperativas, clubes esportivos, agências profissionalizantes etc.

Nesse contexto, podemos observar que a reforma psiquiátrica é consequência do processo de transformação da própria ciência, criticada pelo positivismo e pela pretensão de neutralidade em relação ao seu objeto de estudo, uma vez que a produção do conhecimento científico sofre influências de natureza ideológica, política e ética (Amarante, 2007). 


\section{CAPÍTULO II - Territorialidade}

Examinando as diversas definições de território defendidas pelas ciências humanas, Haesbaert (2009) constatou que a elaboração de cada um dos conceitos de território salienta determinado enfoque ou aduz a uma determinada perspectiva em especial. Por exemplo: a Ciência Política propõe o conceito de território ligado à questão das relações de poder; a Economia tende a salientar a questão da produção no território; a Antropologia enfatiza o aspecto simbólico do território; a Sociologia destaca as relações sociais estabelecidas no território; a Psicologia trata do território como espaço de construção e desenvolvimento da subjetividade por meio das relações sociais; a Geografia tende a lidar com o território no seu aspecto material e na interação entre sociedade e natureza; na Filosofia, o autor encontrou um conceito de território com uma visão ainda mais ampla, como podemos notar nas palavras de Deleuze e Guattari:

\footnotetext{
Já nos animais, sabemos da importância das atividades que consistem em formar territórios, em abandoná-los ou em sair deles, e mesmo em refazer território sobre algo de uma outra natureza (o etólogo diz que o parceiro ou o amigo de um animal "equivale a um lar", ou que a família é um "território móvel"). Com mais forte razão, o hominídeo, desde seu registro de nascimento, desterritorializa sua pata anterior, ele a arranca da terra para fazer dela uma mão, e a reterritorializa sobre galhos e utensílios. Um bastão, por sua vez, é um galho desterritorializado. É necessário ver como cada um, em qualquer idade, nas menores coisas, como nas maiores provações, procura um território para si, suporta ou carrega desterritorializações, e se reterritorializa quase sobre qualquer coisa, lembrança, fetiche ou sonho (apud Haesbaert, 2009, p. 39).
}

A partir dessas várias concepções de território, Haesbaert (2009) classificou-as em três vertentes básicas, cada qual contendo as propriedades comuns defendidas e apresentadas pelas ciências humanas sobre o conceito de território, quais sejam, uma visão política ou jurídica; uma visão cultural ou simbólica; e uma visão econômica de território.

A visão política ou jurídica compreende o território como espaço de relações de poder em geral e de relações de poder institucionalizadas. A vertente cultural ou simbólica contempla o território como objeto de apropriação simbólica e subjetiva por parte de seus grupos territoriais. A visão econômica entende o território como fonte de 
recursos das relações econômicas, onde são estabelecidos os conflitos de classes, decorrente do embate entre o capital e a força de trabalho, ou seja, na divisão social do trabalho.

A partir dessas observações sobre as concepções de território propostas pelas ciências humanas, que não são contraditórias, ao contrário, são harmônicas entre si, na medida em que enfatizam determinados aspectos do território, guardando conexões e entrecruzando-se em função da complexidade do conceito de território, Haesbaert (2009) propõe abordar o território como um espaço que não pode ser considerado nem estritamente natural nem unicamente político, econômico ou cultural. Para o autor, território só poderia ser concebido através de uma perspectiva integradora entre essas diferentes dimensões sociais. Uma concepção integradora de território capaz de comtemplar a polissemia e a riqueza das dimensões sociais que o território manifesta. Uma visão de território como espaço híbrido, numa complexa relação da sociedade com a natureza, e das relações entre política, economia e cultura. O território entendido como a interação de múltiplas relações de poder: materiais (relações econômico-políticas) e simbólicas (relações culturais).

Ao propor o território integrado, Haesbaert (2009) salienta a importância de estruturar o território numa rede que permita o acesso e conexão com outros pontos: "vivíamos sob o domínio da lógica dos territórios-zona, que mais dificilmente admitiam sobreposições, enquanto hoje temos o domínio dos territórios-rede, espacialmente descontínuos, mas intensamente conectados e articulados entre si." (p. 79). Esse domínio dos territórios-rede, que implica na sobreposição territorial e subverte a "mobilidade concreta" para uma mobilidade "virtual" é chamado pelo autor de multiterritorialidade.

O conceito de territorialidade integrada proposto por Haesbaert (2009) reflete, ao mesmo tempo, a questão da territorialidade não integrada, ou seja, nos permite analisar situações e circunstâncias que enfraquecem o conceito de território integrado. Esse arrefecimento ou mitigação da integração territorial é chamado pelo autor de desterritorialização ou de territorialização precária, que nas suas palavras:

Desterritorialização, se é possível utilizar a concepção de uma forma coerente, nunca "total" ou desvinculada dos processos de (re)territorialização, deve ser aplicada a fenômenos de efetiva instabilidade ou fragilização territorial, principalmente entre grupos socialmente mais excluídos e/ou profundamente segregados e, como tal, de fato impossibilitados de construir e exercer efetivo controle 
sobre seus territórios, seja no sentido de dominação políticoeconômica, seja no sentido de apropriação simbólico-cultural. (p. 312)

Desterritorialização aqui é vista em seu sentido forte, ou aquele que podemos considerar o mais estrito, a desterritorialização como exclusão, privação e/ou precarização do território enquanto "recurso" ou "apropriação" (material e simbólica) indispensável à nossa participação efetiva como membros de uma sociedade. (p. 315)

Nesse sentido, Haesbaert (2009) aponta as prisões como exemplos desses processos de desterritorialização, vez que os internos são relegados a territórios (cárceres) controlados não por eles próprios, mas controlados por outros (Autoridades) que promovem a desterritorialização ou a reterritorialização desses internos.

Com efeito, o conceito de territorialidade integrada nos remete a analise de eventos que possam comprometer essa "totalidade" territorial e, por conseguinte, interferir nas possibilidades dos sujeitos apreenderem a riqueza, os recursos e os potenciais do território, bem como do próprio território se beneficiar dos potenciais dos sujeitos. Esse entendimento sobre o território como integrado é fundamental para a compreensão deste estudo, sobretudo em função das consequências relativas aos processos de precarização territorial ou de desterritorialização. 


\section{CAPÍTULO III - Direitos da criança e do adolescente}

Os direitos da criança e do adolescente, no ordenamento jurídico vigente só podem ser compreendidos à luz da doutrina da proteção integral, que rompeu com a doutrina da situação irregular, adotada pelo então Código de Menores ${ }^{14}$.

A doutrina da proteção integral, admitida como base do Estatuto da Criança e do Adolescente $^{15}$ encontra respaldo na Constituição Federal da República ${ }^{16}$ e em documentos da Organização das Nações Unidas ${ }^{17}$. Essa doutrina estabelece, basicamente, que a atenção a crianças e adolescente seja de ordem absolutamente prioritária e que a proteção da criança e do adolescente seja de encargo da família, da sociedade e do Estado, na garantia da satisfação de todas as necessidades:

É dever da família, da sociedade e do Estado assegurar à criança, ao adolescente e ao jovem, com absoluta prioridade, o direito à vida, à saúde, à alimentação, à educação, ao lazer, à profissionalização, à cultura, à dignidade, ao respeito, à liberdade e à convivência familiar e comunitária, além de colocá-los a salvo de toda forma de negligência, discriminação, exploração, violência, crueldade e opressão. (art. 277 da Constituição Federal)

Como princípios estruturantes da doutrina da proteção integral, o artigo $3^{\circ}$ do Estatuto da Criança e do adolescente estabelece três princípios:

A criança e o adolescente gozam de todos os direitos fundamentais inerentes à pessoa humana, sem prejuízo da proteção integral de que trata esta Lei, assegurando-se-lhes, por lei ou por outros meios, todas as oportunidades e facilidades, a fim de lhes facultar $o$ desenvolvimento físico, mental, moral, espiritual e social, em condições de liberdade e de dignidade.

O primeiro princípio, contido no início do referido artigo (“A criança e o adolescente gozam de todos os direitos fundamentais inerentes à pessoa humana...”) afirma a plena capacidade jurídica das crianças e dos adolescentes em relação aos direitos fundamentais, estabelecendo correspondência com os mesmos direitos fundamentais de que são titulares as pessoas adultas. O segundo princípio da doutrina da proteção integral, constante da parte intermediária do artigo $3^{\circ}$ do E.C.A. (“... sem

\footnotetext{
${ }^{14}$ Lei 6.697, de 10 de dezembro de 1979.

${ }^{15}$ Art. 1ㅇ e 3o da Lei 8.069, de 13 de julho de 1990.

${ }^{16}$ Art. 227 da Constituição da República Federativa do Brasil.

${ }^{17}$ Convenção sobre os Direitos da Criança, de 20 de novembro de 1989.
} 
prejuízo da proteção integral de que trata esta Lei..."), consagra a compatibilidade entre o reconhecimento dos direitos fundamentais às crianças e adolescentes e a proteção integral que lhes é atribuída pelo próprio Estatuto. O terceiro princípio, presente na parte final do mesmo dispositivo ("assegurando-se-lhes, por lei ou por outros meios, todas as oportunidades e facilidades, a fim de lhes facultar o desenvolvimento físico, mental, moral, espiritual e social, em condições de liberdade e de dignidade.") garante às crianças e adolescentes todos os meios e instrumentos capazes de efetivar o desenvolvimento físico, mental, moral, espiritual e social (Cury, 2002).

A efetividade desses princípios atinentes à doutrina da proteção integral, quando ameaçados ou violados, é subsidiada pela aplicação de medidas específicas de proteção, chamadas de medidas protetivas. Prescritas no art. 101 do E.C.A. ${ }^{18}$, essas medidas protetivas são aplicáveis às crianças e adolescentes carentes e também aos adolescentes em conflito com a lei.

Diferentemente das crianças, entendidas como pessoas de até 12 anos de idade incompletos, que estão sujeitas apenas às medidas protetivas, por força do artigo 105 do E.C.A. ${ }^{19}$, os adolescentes em conflito com a lei, ou seja, que praticaram atos infracionais (condutas tipificadas como infrações penais: contravenções ou crimes) estão sujeitos tanto às medidas protetivas quanto às medidas socioeducativas, que podem ser aplicadas pelo Juízo da Infância e da Juventude de forma cumulativa. As medidas socioeducativas estão dispostas no artigo 112 do Estatuto $^{20}$, que prevê taxativamente as medidas que podem ser aplicadas aos adolescentes em conflito com a lei.

\footnotetext{
${ }^{18}$ Art. 101. Verificada qualquer das hipóteses previstas no art. 98, a autoridade competente poderá determinar, dentre outras, as seguintes medidas: I - encaminhamento aos pais ou responsável, mediante termo de responsabilidade; II - orientação, apoio e acompanhamento temporários; III - matrícula e frequência obrigatórias em estabelecimento oficial de ensino fundamental; IV - inclusão em programa comunitário ou oficial de auxílio à família, à criança e ao adolescente; V - requisição de tratamento médico, psicológico ou psiquiátrico, em regime hospitalar ou ambulatorial; VI - inclusão em programa oficial ou comunitário de auxílio, orientação e tratamento a alcoólatras e toxicômanos; VII - abrigo em entidade; VIII - colocação em família substituta.

${ }^{19}$ Art. 105. Ao ato infracional praticado por criança corresponderão as medidas previstas no art. 101.

${ }^{20}$ Art. 112. Verificada a prática de ato infracional, a autoridade competente poderá aplicar ao adolescente as seguintes medidas: I - advertência; II - obrigação de reparar o dano; III - prestação de serviços à comunidade; IV - liberdade assistida; V - inserção em regime de semiliberdade; VI - internação em estabelecimento educacional; VII - qualquer uma das previstas no art. 101, I a VI.
} 


\section{PERCURSO METODOLÓGICO}

Este estudo foi subsidiado empiricamente por dados de processos judiciais das Varas Especiais da Infância e da Juventude da comarca de São Paulo que continham decisões judiciais determinando o encaminhamento de crianças e adolescentes usuários de substâncias psicoativas para tratamento no campo da saúde mental. A análise documental se valeu da técnica de Análise do Discurso, cujos resultados foram discutidos à luz do referencial teórico do materialismo histórico-dialético.

\subsection{Referencial teórico-filosófico do materialismo histórico-dialético}

O estudo das decisões do Poder Judiciário no campo da saúde mental, pretendendo conhecer e compreender a orientação das decisões judiciais de encaminhamento de crianças e adolescentes para tratamento, se em favor do paradigma da psiquiatria tradicional ou se no sentido do modelo da reforma psiquiátrica, requereu um referencial teórico de perspectiva totalizante, que levasse em conta os processos históricos do movimento de transformação das práticas e saberes do campo da saúde mental e que procurasse refletir sobre os interesses sociais contidos nas demandas submetidas à instituição judiciária.

Nesse sentido, o referencial teórico adotado como norteador deste estudo compreendeu o do materialismo histórico-dialético, vez que este busca produzir

conhecimento com base em uma visão totalizante, abordando o fenômeno como realidade histórica e social em processo constante de transformação, dadas as contradições contidas no próprio fenômeno social.

A compreensão de um fenômeno depende do estudo das relações que estabelecem sua formação e que o inserem em uma totalidade, a qual também determina o fenômeno e da qual ele não pode ser isolado, "sob pena de se perder a compreensão do movimento que constitui o fenômeno e, nesse caso, a compreensão do próprio fenômeno" (Andery, 2003).

O materialismo dialético e o materialismo histórico, legados por Marx e por Engels, compõem dois blocos de saber interligados, sendo o materialismo dialético 
"uma teoria geral do ser que [...] privilegia o movimento e as contradições e toma o mundo material como o dado primário que, na consciência, dado secundário, aparece como reflexo". Já o materialismo histórico consiste na "aplicação dos princípios do materialismo dialético ao estudo da sociedade" (Netto, 2006).

A dialética materialista "estuda as formas gerais do ser, os aspectos e os laços gerais da realidade, as leis do reflexo desta última na consciência dos homens". A dialética apresenta leis e categorias, que se diferenciam em função de as primeiras refletirem "as ligações e as relações universais, enquanto que as categorias refletem, além disso, as propriedades e os aspectos universais da realidade objetiva", revelando maior riqueza no conteúdo das categorias (Cheptulin, 1982).

As leis da dialética compreendem a lei da unidade e luta dos contrários, da passagem da quantidade à qualidade e da negação da negação. A lei da unidade e luta dos contrários estabelece que aspectos e tendências opostas são inerentes a todos os objetos, constituindo uma propriedade da estrutura de qualquer objeto e processo a interconexão e a negação mútua dos contrários. Esta "luta dos contrários é a força motriz, a fonte do desenvolvimento". A lei da passagem da quantidade à qualidade assevera que qualidade e quantidade são aspectos de um mesmo fenômeno. A depender da medida ou intensidade da quantidade de determinadas propriedades essenciais, $o$ fenômeno transmuta-se, "dando lugar a um novo". A lei da negação da negação caracteriza-se pela propriedade do objeto servir "de condição prévia para o aparecimento de formas novas, superiores e mais perfeitas" e por significar que "o novo, na qualidade de negação do antigo, não deixa atrás de si um deserto, não o destrói simplesmente, mas como que o 'supera”' (Konstantinov, 1975).

As categorias da dialética se encontram "em estreita ligação com as suas leis básicas", que se exprimem e se formulam "unicamente através de certas categorias", quais sejam, 1) Singular, Particular e Geral: "cada objeto é uma unidade do geral e do singular. O particular surge como se fosse um elo de ligação entre o singular e o geral"; 2) Causa e Efeito: "são conceitos correlativos. O fenômeno que dá origem a outro fenômeno é a causa deste. O resultado da ação da causa é o efeito"; 3) Necessidade e Acaso: "nem todo o necessário é inevitável. Casual é aquilo que, em dadas condições, pode ocorrer mas também pode não ocorrer"; 4) Possibilidade e Realidade: "a existência do novo no seu estado potencial é precisamente a possibilidade. Entende-se por realidade uma possibilidade realizada - algo que já passou a existir, que se 
desenvolveu"; 5) Conteúdo e Forma: "forma e conteúdo estão unidos: não há e não pode haver conteúdo sem forma nem forma isenta de conteúdo. Forma e conteúdo são contrários que constituem uma unidade, são polos diferentes duma e mesma coisa"; 6) Essência e Fenômeno: “enquanto que a essência é algo de geral, o fenômeno é singular (...) enquanto que a essência é algo de estável e necessário, o fenômeno é mais efêmero, mutável e casual" (Konstantinov, 1975).

Essas leis e categorias, aplicadas ao estudo da sociedade, constituem a abordagem do materialismo histórico-dialético, que "examina as instituições sociais como determinadas, 'em última instância', pela infraestrutura econômica." (Netto, 2006).

A fim de compreender as relações jurídicas, Marx nos ensina que devemos procurar a explicação nas "relações materiais de vida", isto é, nas relações ligadas pelos interesses e necessidades materiais de indivíduos e de grupos sociais porque estão na base mesma das decisões jurídicas, políticas culturais etc. (Malagodi, 1988).

Pesquisar a orientação do Judiciário sobre o modelo de cuidado em saúde mental (tradicional ou da reforma psiquiátrica) adotado no caso concreto sob o referencial teórico-filosófico do materialismo histórico-dialético implica examinar as decisões judiciais como processos da atividade humana, histórica e socialmente produzida e produtora da existência social, no seu constante curso de transformação.

Com efeito, visando ao desenvolvimento desse conhecimento nos seus aspectos gerais, adotou-se a ideologia como categoria de análise para a apreensão das ideias, significados e representações contidas nas decisões judiciais. As categorias de análise "são aquelas que retêm historicamente as relações sociais fundamentais e podem ser consideradas balizas para o conhecimento do objeto nos seus aspectos gerais" (Minayo, 2004).

A ideologia consiste num "sistema ordenado de ideias ou representações e das normas e regras como algo separado e independente das condições materiais”. Essas formações ideológicas são formadas por ideias ou representações tomados como “independentes de realidade histórica e social, quando na verdade é essa realidade que torna compreensíveis as ideias elaboradas e a capacidade ou não que elas possuem para explicar a realidade que as provocou" (Chauí, 2004). 
Chauí (2004) ensina que o Direito é o instrumento utilizado pelo Estado para "fazer com que a dominação não seja tida como uma violência, mas como legal, e por ser legal e não-violenta deve ser aceita". Esse entendimento só é possível através da ideologia, que substitui a realidade do Estado (dominação de uma classe) pela ideia do Estado (interesse geral) e substitui a realidade do Direito (dominação de uma classe através das leis) pela ideia do Direito (leis tidas como legítimas, justas, boas e válidas para todos).

\subsection{Abordagem qualitativa de pesquisa}

A análise das decisões do Poder Judiciário no campo da saúde mental depende da apreensão das motivações, interesses e valores que determinam o sentido de suas decisões.

Com efeito, a apreensão desse sentido depende de uma abordagem qualitativa de pesquisa, que "trabalha com o universo dos significados, dos motivos, das aspirações, das crenças, dos valores e das atitudes" (Minayo, Deslandes, Gomes, 2008) e há sempre uma "tentativa de capturar a perspectiva dos participantes, isto é, a maneira como os informantes encaram as questões que estão sendo focalizadas" (Ludke, André, 1986).

\subsection{Pesquisa e análise documental}

Para a realização de estudos nos quais a fonte de coleta de dados está restrita a documentos, como no caso deste estudo, Marconi e Lakatos (2007) indicam a adoção da pesquisa documental como técnica para a obtenção dos objetivos propostos e apontam os documentos jurídicos como uma fonte rica de informações, que mostram "como uma sociedade regula o comportamento de seus membros e de que forma se apresentam os problemas sociais" (p. 180).

A pesquisa documental, de acordo com Gil (2002), caracteriza-se por valer-se de fontes de dados primários e estáveis, ou seja, baseia-se em dados que ainda não foram objeto de tratamento analítico. Na análise documental, Silva Júnior (2011) invoca dois processos: crítica externa e crítica interna da fonte. A primeira refere-se à autenticidade, 
à credibilidade da fonte. Por vezes, é necessário recorrer aos conhecimentos da linguística, semântica e lexicologia, dentre outros, para se aproximar do sentido original do texto. Já a crítica interna do documento se refere à interpretação do texto, à hermenêutica e à exegese.

\subsection{Fonte documental}

Este estudo delimitou a fonte documental de pesquisa ao acervo dos autos dos processos judiciais das Varas Especiais da Infância e da Juventude da Comarca de São Paulo que contenham decisões determinando o encaminhamento de crianças e adolescentes usuários de substâncias psicoativas para tratamento no campo da saúde mental.

As Varas Especiais da Infância e da Juventude da Comarca de São Paulo constituem Juízos de Direito de Primeira Instância competentes para apreciar demandas judiciais envolvendo crianças e adolescentes, conforme disposto no Estatuto da Criança e do Adolescente ${ }^{21}$.

\subsection{Autorização para acesso à fonte documental}

Por força do disposto na Constituição Federal (art. $5^{\circ}$, inciso $\mathrm{LX}^{22}$ ), no Estatuto da Criança e do Adolescente (art. $143^{23}$ ) e no Código de Processo Civil (art. $155^{24}$ ), os processos judiciais do Juízo da Infância e da Juventude correm em segredo de justiça.

Com efeito, a realização desta pesquisa documental no acervo de processos judiciais das Varas Especiais da Infância e da Juventude da Comarca de São Paulo dependeu de prévia autorização do Excelentíssimo Senhor Doutor Juiz de Direito das Varas Especiais da Infância e Juventude do Estado de São Paulo, requerida formalmente

\footnotetext{
${ }^{21}$ Estatura da Criança e do Adolescente, art. 145 e seguintes do (Brasil, 1994).

${ }^{22 ،}$ “A lei só poderá restringir a publicidade dos atos processuais quando a defesa da intimidade ou o interesse social o exigirem" (Brasil, 1994)

${ }^{23}$ “E vedada a divulgação de atos judiciais, policiais e administrativos que digam respeito a crianças e adolescentes a que se atribua autoria de ato infracional" (Brasil, 1994).

${ }^{24}$ “Os atos processuais são públicos. Correm, todavia em segredo de justiça os processos: I- em que o exigir o interesse público; II - que dizem respeito a casamento, filiação, separação dos cônjuges, conversão desta em divórcio, alimentos e guarda de menores" (Brasil, 1994)
} 
mediante petição constando o compromisso ético do autor deste estudo de preservar o sigilo e a confidencialidade dos dados processuais, resguardando o segredo de justiça e com as devidas cautelas.

\subsection{Segredo de justiça e sigilo dos dados}

A preservação do segredo de justiça e do sigilo dos dados processuais foi garantida pela substituição de todas as informações que poderiam levar à identificação do processo e das respectivas pessoas envolvidas, como as crianças, os adolescentes e seus familiares; os magistrados; os membros do Ministério Público; os Defensores Públicos, os advogados; os serventuários da Justiça; os conselheiros tutelares; os policiais; os profissionais de saúde e de assistência social; os educadores; e demais pessoas que eventualmente participaram do processo.

\subsection{Comitê de ética em pesquisa}

Tratando-se de pesquisa envolvendo seres humanos e visando assegurar a dignidade e a proteção dos sujeitos da pesquisa ${ }^{25}$, o presente estudo foi submetido e aprovado pelo Comitê de Ética em Pesquisa da Escola de Enfermagem da Universidade de São Paulo (CEP-EEUSP) sob o parecer de $n^{\circ} 140.063$.

\subsection{Coleta de dados}

A partir da autorização judicial concedida para a realização da coleta de dados em uma determinada Vara Especial da Infância e da Juventude da comarca de São Paulo, todo o acervo dos processos do respectivo Ofício desta Vara Especial da Infância e da Juventude foi explorado com o objetivo de selecionar as amostras cabíveis para o estudo, quais sejam, processos que continham decisões judiciais de encaminhamento de adolescentes usuários de substâncias psicoativas para tratamento no campo da saúde

\footnotetext{
${ }^{25}$ Conselho Nacional de Saúde, Resolução 196/1996 (Brasil, 1996).
} 
mental. Após a exploração do acervo, que contava com aproximadamente dois mil autos de processos, foram selecionadas cinco amostras que compuseram as exigências preestabelecidas.

\subsection{Análise do discurso como estratégia de analise documental}

Cabe esclarecer e justificar a adoção, em especial, da estratégia da Análise do Discurso para o tratamento dos dados coletados neste estudo, bem como apontar as principais premissas e técnicas da Análise do Discurso que orientaram e fundamentaram o trabalho analítico.

A técnica de Análise do Discurso foi adotada como estratégia de análise documental levando-se em conta a coadunação entre suas possibilidades analíticas e os objetivos propostos neste estudo.

Nesse sentido, o objetivo de analisar a orientação das decisões judiciais no campo da saúde mental está em congruência com o objetivo da Análise do Discurso, dirigido a inferir qual a visão de mundo enunciada pelos sujeitos e revelar os determinantes dessa visão (Fiorin, 2007).

Além disso, a Análise do Discurso encontra coerência com os objetivos do estudo em virtude de abordar as relações entre discurso e poder. No caso do poder do discurso jurídico, van Dijk (2010) aponta que esse poder, cristalizado nos textos institucionais, é exercido através de um rígido e explícito sistema de controle dos processos discursivos, que gerenciam os turnos das falas e selecionam os conteúdos considerados pertinentes pelos articuladores desse poder.

Em termos de premissas, Reuter (2002) nos adverte sobre um princípio básico de análise, qual seja, a necessidade de distinguirmos o texto do não-texto. Essa diferença implica em estabelecermos as diferenças entre os planos do enunciado (produto da enunciação) e da enunciação (produção do enunciado); da ficção (texto) e do referente (realidade); do autor (pessoa natural) e do narrador (enunciador inscrito no texto), do leitor (pessoa natural) e do narratário (enunciatário inscrito no texto).

Acompanhando o entendimento de Fiorin (2007), a Análise do Discurso pressupõe que o discurso é social, produto de determinações sociais e não está afeto ao 
âmbito exclusivamente individual. Isso porque a consciência humana é social, formada, pois, pelo conjunto dos discursos presentes na sociedade, que são interiorizados pelos indivíduos que a compõem. Com efeito, o discurso dos indivíduos não é produzido independentemente por eles, mas é reproduzido em suas falas pelo fato de ser derivado dos discursos que assimilam no seio social em que estão inseridos.

Pela sua formação social, o discurso materializa e expressa as ideologias. O discurso é o veículo de reprodução das formações ideológicas, cujo enunciador expressa o conteúdo ideológico pertinente ao seu respectivo grupo social, salientando-se que apesar de haver diversas formações ideologias na sociedade, a ideologia dominante corresponde à formulada pelas classes dominantes. Nesse sentido, as ideologias constituem um componente pré-semântico do discurso, determinando e influenciando seu componente semântico. Esse fenômeno revela que o discurso tem uma função citativa, na medida em que cita, repete, menciona e reproduz outros discursos (Fiorin, 2007).

Para procedemos à Análise do Discurso, Fiorin (2011) ensina que essa tarefa se destina a analise dos diferentes elementos constitutivos do discurso e que devemos inicia-la pelos elementos dos níveis mais superficiais e concretos do texto, seguindo-se para a análise dos elementos dos patamares mais abstratos e profundos, num movimento contínuo que se dirige do mais complexo para o mais simples, empregando-se um caminho inverso ao do processo normal de produção dos textos.

Essa forma de Análise do Discurso recomendada pelo autor corresponde ao chamado percurso gerativo de sentido, ou seja, a análise deve partir do patamar mais perceptível e fenomênico do texto para a análise de seus sucessivos patamares mais gerais e abstratos com a finalidade de estabelecer modelos de sentido invariáveis, subjacentes aos elementos de nível superficial.

A realização do percurso gerativo de sentido de um texto depende da identificação e da apresentação de três patamares ou níveis de sentido: um patamar de superfície, chamado de nível discursivo; um patamar mais abstrato, também conhecido por nível narrativo; e um nível ainda mais geral e abstrato, chamado de nível profundo ou fundamental. Cada um desses níveis do percurso gerativo de sentido (discursivo, narrativo e fundamental) dispõe simultaneamente de componentes semânticos e componentes sintáxicos (Fiorin, 2011). 
O nível discursivo do percurso gerativo de sentido constitui o patamar de revestimento e de concretização das narrativas, que possibilita a ocorrência de variações de conteúdo. Essa possibilidade é devida aos componentes semânticos e sintáxicos próprios do nível discursivo. Esse é o nível de manifestação das formações ideológicas. A semântica discursiva reveste e concretiza as transformações e mudanças de estado do nível narrativo por meio da inserção de temas e de figuras no texto. Os temas são investimentos semânticos com função predicativa e interpretativa, que buscam explicar o mundo. Já as figuras remetem ao campo natural e têm função descritiva e representativa, visando simular o mundo. O componente sintáxico do discurso analisa os elementos constituintes do discurso: as pessoas, o espaço e o tempo. Além disso, a sintaxe discursiva analisa as relações entre o enunciador (que produz o enunciado) e o enunciatário (a quem é dirigida o enunciado) e as projeções (as marcas) da enunciação no enunciado (Fiorin, 2011).

O patamar narrativo do percurso gerativo apresenta as transformações entre estados sucessivos e distintos como componente semântico. A sintaxe narrativa comporta os enunciados de estado (relações de junção) e de fazer (transformação). Esses enunciados, quando complexos, podem ser analisados em fases: manipulação, competência, performance e sanção. A fase de manipulação caracteriza-se pela ação de um sujeito sobre outro a fím de determiná-lo a algo. A competência constitui a capacidade ou a qualidade de que é dotado o sujeito que realiza a transformação. A fase da performance consiste no momento em que se opera a transformação na narrativa. A sanção é a fase de verificação de que a transformação (performance) se efetivou. No nível profundo ou fundamental, o componente semântico compreende a categoria básica do sentido do texto, constituindo-se de modelos de sentido invariantes. Essa categoria assume qualidades positivas (sentido eufórico) ou negativas (sentido disfórico). Seu componente sintáxico abrange duas operações: uma negação e uma asserção (Fiorin, 2011).

\subsection{Observações sobre a apresentação e análise das amostras documentais}


Em coerência com os objetivos propostos neste estudo, as amostras documentais coletadas são compostas de decisões judiciais originárias do Juízo de Direito da Infầncia e da Juventude de São Paulo.

Os documentos das amostras abrangem não apenas os documentos referentes às decisões judiciais em si, mas aos demais documentos que instruíram a ação. Esses documentos que guardar conexão com as deliberações judiciais, apesar de não constituírem o foco central da presente análise em função dos objetivos deste trabalho orientação das decisões judiciais no campo da saúde mental, são apresentados para os fins da própria análise dos discursos judiciais, uma vez que tais textos estabelecem uma intertextualização e dialogam uns com os outros num processo contínuo de inter-relação e influencia recíproca.

Esses documentos correspondem aos textos institucionais que contêm as intervenções, pareceres e manifestações dos órgãos do Ministério Público, da Defensoria Pública, da Fundação CASA (Centro de Atendimento Socioeducativo ao Adolescente) e da Polícia Civil.

Os processos judiciais do Juízo de Direito da Infância e da Juventude, por cuidarem de fatos e de direitos envolvendo crianças e adolescentes, correm em segredo de justiça por força do disposto na Constituição Federal (art. 5o, inciso LX ${ }^{26}$ ), no Estatuto da Criança e do Adolescente (art. $143^{27}$ ) e no Código de Processo Civil (art. $\left.155^{28}\right)$.

Com vistas a preservar a confidencialidade e o sigilo das informações contidas nesses documentos protegidos legalmente pelo segredo de justiça, os textos presentes nos documentos das amostras são reproduzidos neste trabalho da maneira mais fiel possível ao seu formato original, garantindo a genuinidade e integridade dos conteúdos textuais em harmonia com o dever de resguardar o sigilo das informações.

Com efeito, os textos originais inscritos nos documentos das amostras são reproduzidos neste trabalho com as devidas cautelas, respeitando-se a confidencialidade

\footnotetext{
26“"A lei só poderá restringir a publicidade dos atos processuais quando a defesa da intimidade ou o interesse social o exigirem" (Brasil, 1994).

${ }^{27}$ “É vedada a divulgação de atos judiciais, policiais e administrativos que digam respeito a crianças e adolescentes a que se atribua autoria de ato infracional" (Brasil, 1994).

${ }^{28}$ “Os atos processuais são públicos. Correm, todavia em segredo de justiça os processos: I- em que o exigir o interesse público; II - que dizem respeito a casamento, filiação, separação dos cônjuges, conversão desta em divórcio, alimentos e guarda de menores" (Brasil, 1994).
} 
dos dados. Os textos são reproduzidos com adaptações relativas a dados e circunstâncias peculiares que poderiam eventualmente comprometer o segredo de justiça.

Nesse sentido, informações relativas à identidade de pessoas, como nomes próprios, são substituídas por substantivos comuns, como na hipótese do uso da palavra "adolescente" em substituição ao nome real do adolescente ou no uso das palavras “pai", "padrasto", “mãe”, "madrasta”, “irmão", “irmã”, "Fulano", "Sicrano" e "Beltrano" para designar familiares e pessoas, cujos nomes reais são enunciados nos textos.

Os nomes próprios também são substituídos nos textos das amostras documentais pelos respectivos cargos e funções que ocupam, como nos casos dos magistrados, dos membros do Ministério Público, dos advogados, dos serventuários da Justiça, dos Conselheiros Tutelares, dos policiais, dos educadores e dos profissionais da saúde e da assistência social.

Da mesma forma e para evitar que elementos e circunstâncias particulares possam de algum modo identificar os processos, são empregadas no texto as palavras "tal", "tais", "tanto", "tantos" e "tantas" em substituição a informações referentes a logradouros, datas, horários, números de processos judiciais, números de Varas e respectivos Ofícios Judiciais, quantidades de substâncias psicoativas apreendidas e outros dados peculiares que possam expor a riscos o sigilo das informações e a confidencialidade.

A edição dos textos com as substituições de nomes, detalhes e particularidades são evidenciadas aos leitores neste trabalho pela formatação em "Itálico" ${ }^{29}$ das palavras substituídas, permitindo o reconhecimento imediato de suas ocorrências durante o curso da leitura.

Os textos são reproduzidos com os mesmos padrões e destaques conferidos pelos autores nos textos originais, como o uso de grifos, letras maiúsculas, negritos, parágrafos, aspas etc..

A fim de auxiliar a compreensão do leitor em função de alguns textos das amostram apresentarem referências expressas a dispositivos legais, acrescentamos em notas de rodapé o teor dos respectivos diplomas legais.

\footnotetext{
29،"Diz-se do tipo de realce inclinado para a direita; grifo" (Ferreira, 1993).
} 
As amostras se encontram nos apêndices deste estudo e são apresentadas na seguinte ordem: em primeiro lugar a reprodução dos textos oriundos do Juízo de Direito seguidos dos resultados analíticos e, em segundo lugar, a reprodução dos textos elaborados pelos demais órgãos, entre os quais são intercaladas as respectivas observações analíticas. 


\section{RESULTADOS}

A fim de nos aproximarmos da satisfação dos objetivos propostos neste estudo, apresentaremos num primeiro momento os resultados alcançados pela análise documental e, num segundo momento, a discussão desses resultados à luz do referencial teórico-metodológico do materialismo dialético-histórico.

Iniciaremos a exposição dos resultados pela caracterização do perfil socioeconômico dos adolescentes referidos nas amostras, seguida dos resultados empíricos relativos à categoria analítica da ideologia, finalizando com a apresentação detalhada das decisões judiciais de encaminhamento dos adolescentes aos serviços de saúde mental.

\subsection{Caracterização do perfil socioeconômico dos adolescentes referidos nas amostras}

À época em que os cinco processos judiciais que compõem as amostras coligidas neste trabalho estavam em curso, o perfil dos cinco adolescentes referidos respectivamente a cada um desses processos apresentava os seguintes característicos socioeconômicos:

- os cinco adolescentes, todos do sexo masculino, contavam com idades entre 14 e 17 anos, sendo um de 14 anos, dois de 16 e dois jovens com 17 anos;

- um dos cinco adolescentes vivia em situação de rua e os demais possuíam residência "fixa", na qual conviviam com a família;

- as mães de todos os adolescentes estavam vivas e, com exceção do jovem em situação de rua, conviviam com os adolescentes;

- constam informações sobre os pais de três dos cinco adolescentes, os quais não conviviam com os jovens nem com as mães destes;

- a origem da renda da família dos adolescentes foi atribuída, em quatro das cinco amostras, às mães dos jovens, sendo que duas delas eram empregadas domésticas e as demais trabalhavam como copeira e ajudante de limpeza em prédio residencial. 
Com relação à única mãe que não constava informações sobre o trabalho, há o registro de que se achava acometida de câncer e de HIV positivo;

- o valor da renda da família dos adolescentes encontra-se referido em duas das cinco amostras: setecentos reais $(\mathrm{R} \$ 700,00)$ provenientes do salário de empregada doméstica num caso e quinhentos e quarenta e cinco reais $(\mathrm{R} \$ 545,00)$ de salário como ajudante de limpeza em prédio residencial mais cento e sessenta e quatro reais (R\$ 164,00) advindos do programa social denominado "Bolsa Família";

- o nível de escolaridade dos adolescentes não ultrapassava o ensino fundamental, sendo que nenhum deles estava estudando na época da instauração dos processos. Há o registro de que dois adolescentes concluíram o nível fundamental, outros dois jovens interromperam os estudos na $4^{\mathrm{a}}$ série um adolescente parou de estudar na $6^{\mathrm{a}}$ série do ensino fundamental.

- com exceção da falta de informação sobre um dos adolescentes (de 14 anos de idade), os demais não estavam trabalhando, havendo referências de que um deles havia exercido as funções de servente de pedreiro e de lavador de carros e o outro jovem havia trabalhado como ajudante em oficina mecânica;

- todos os adolescentes referiram o consumo de substâncias psicoativas, como maconha, cocaína, crack e solventes, sendo que dois deles afirmaram o hábito de utilizar apenas uma dessas substâncias, enquanto os demais declararam fazer uso de várias delas.

\subsection{Categorias empíricas}

A técnica de Análise do Discurso, utilizada como estratégia de análise documental neste estudo, possibilitou a identificação de um modelo de sentido invariante, comum a todas as amostras analisadas. Esse modelo invariável e constante em todos os discursos abrigou a categoria semântica: atividade versus passividade, conferindo a esta qualidade eufórica (ou positiva) em detrimento daquela, considerada disfórica (ou negativa).

A partir da identificação dessa estrutura semântica fundamental (atividade versus passividade), de que são dotadas todas as amostras analisadas, podemos dar sentido ao 
conjunto dos elementos dos níveis superficiais dos discursos, dentre os quais, notadamente, as formações ideológicas, na medida em que a ideologia corresponde à categoria analítica adotada neste estudo.

Com efeito, podemos reconhecer como formações ideológicas que guardam consonância com os objetivos do estudo, ideologias ligadas, sobretudo, ao âmbito familiar, social e do conhecimento, em decorrência da função de relevo que exercem na fundamentação das decisões atinentes ao atendimento em saúde mental. Essas formações ideológicas relativas à esfera familiar, social e do conhecimento são nomeadas neste trabalho, a título de categorias empíricas, sob as rubricas: "família", "círculo social" e "competência".

As categorias empíricas: família, círculo social e competência sintetizam os modelos ideológicos de que se valem os discursos judiciais e extrajudiciais para fundamentar e basilar entendimentos no campo da saúde mental. Essas categorias guardam coerência com o modelo semântico invariável revelado pela análise dos discursos, composto pela oposição: atividade e passividade, pois representam relações entre elementos que operam em posições ativas e passivas, funcionando na qualidade de agentes e pacientes.

\subsubsection{Família}

A categoria empírica família pôde ser reconhecida em razão de sua recorrente tematização nos discursos e em virtude da importância que lhe é conferida no conteúdo argumentativo. Nos discursos judiciais, a referência à família aparece explicitamente nas amostras ${ }^{30}$ como elementos de argumentação:

...tendo em conta o amparo familiar. (1)

Além disso, o adolescente não conta com qualquer respaldo familiar, sendo que está fora do convívio familiar há bastante tempo. (4)

De acordo com o relatório técnico juntado aos autos, o adolescente está inserido em família desestruturada... (5)

\footnotetext{
${ }^{30} \mathrm{~A}$ respectiva amostra de onde foram extraídos os discursos ilustrativos é informada ao final de cada frase, entre parênteses.
} 
Observamos que o conceito de família utilizado nos discursos judiciais é baseado num modelo moral, pedagógico e garantidor, capaz de resguardar e assegurar a seus membros condições adequadas de vida. Esse modelo ideológico de família como entidade normativa, abstrata e uniforme não reflete a realidade social e histórica da família, razão pela qual é tomada nos discursos como causa ou circunstância desencadeadora de problemas e não como resultado de relações sociais determinadas em dado momento histórico (Chauí, 2008).

Nesse sentido, podemos constatar que esse modelo ideológico de família é apreendido nos discursos como genético ou catalisador do processo de envolvimento com drogas. A esse respeito, podemos observar a manifestação do Ministério Público:

...passou a fazer consumo de crack há pouco tempo, tendo em vista que está enfrentando dificuldades em lidar com a genitora, que está com vários problemas de saúde (AIDS e câncer). (3)

O adolescente está fora do convívio familiar, em situação de vulnerabilidade. Revela com seu proceder índole infracional latente que precisa ser tratada e revertida em nível institucional para que introjete normas mínimas de convivência em sociedade, sem o que não terá condições de integrá-la como indivíduo adaptado e útil. (4)

Com grande frequência, a Fundação CASA se refere ao modelo ideológico de família como gerador ou como fator de fomento para o envolvimento com substâncias psicoativas:

Após a prisão da genitora o epigrafado abandonou o estudo e começou a usar entorpecentes. (2)

Quando o padrasto estava presente no seu âmbito familiar desencadeava uma dinâmica desarmônica. (2)

... observamos referenciais fragilizados de figura parental. (2)

Sugeriu que o núcleo familiar fragilizado de figura de autoridade e referencial positivo. (2)

Verbaliza que permanecia nas ruas diante dos maus tratos sofridos pelo genitor. (4)

No convívio com a mãe foi onde começou a ir para as ruas, iniciando o uso de drogas com 07 anos de idade... (4)

Encontra-se fora do convívio familiar em situação de vulnerabilidade na região da Luz. (4)

... o ambiente familiar também contribuiu para que o adolescente começasse a permanecer em vias públicas, como maneira de 'fugir' da realidade vivida. (4) 
Podemos observar também que a ideologia da família, além de dissociar o grupo familiar de sua realidade histórica e social, projeta funções e papeis específicos aos seus membros, reproduzindo, por exemplo, ideais de figuras paterna e materna (Chauí, 2008). Essa expectativa de papéis ideais pode ser reconhecida nos discursos da Fundação CASA ao atribuir às figuras que detém o poder familiar a causa ou influência determinante de atitudes e comportamentos dos filhos:

O genitor abdicou em assumir as responsabilidades que lhe cabia, bem como não reconheceu a paternidade legalmente, bem como não representa para o filho uma figura positiva para seu desenvolvimento em virtude da envoltura deste no mundo criminal e ainda a dependência química. (2)

Durante seu desenvolvimento, provavelmente a atividade laborativa das figuras parentais ocasionou a carência de um monitoramento efetivo, além de problemas de relacionamento com a figura paterna devido realizar uso de etílicos... (5)

Os relatos do adolescente indicam que a genitora não consegue dar a devida atenção para todos os filhos, até mesmo pela quantidade de descendentes aliada ao fato de ter que trabalhar para sustentá-los, ficando assim os irmãos se ajudando mutuamente. (4)

Podemos ainda verificar que os discursos da Fundação CASA se valem do modelo ideológico de família para justificar o entendimento de que as famílias necessitam de intervenção institucional, na medida em que enfatizam o fracasso dessas famílias na tarefa de lidar com seus próprios membros:

...conforme seu discurso observamos um adolescente com envolvimento efetivo no tráfico de entorpecente, bem como seu núcleo familiar não consegue coibir e direcioná-lo a uma conduta assertiva de vida. (5)

A genitora necessita de instrumentos de apoio e orientação para que possa zelar mais atentamente pelo acompanhamento e as demandas trazidas pelo filho. (2)

Sugerimos ainda a inserção da genitora em grupo de apoio e orientação à família, a fim de prepará-la para desempenhar, de forma mais constante, papéis de autoridade e imposição de limites ao epigrafado. (2)

$O$ Adolescente revelou que começou a traficar com dez anos de idade, devido o ganho fácil. Na faixa etária dos catorze anos a genitora teve conhecimento, então, a referida buscou persuadi-lo a cessar tal conduta. (5)

Embasada no relato do adolescente e da genitora, esta apresentou uma postura protetora, não conseguindo admitir o envolvimento do filho com o meio delitivo, bem como que ela e o pai do jovem não conseguem impor limites ao mesmo. (5) 


\subsubsection{Círculo social}

A categoria empírica nomeada neste trabalho como círculo social compreende as referências discursivas, de caráter ideológico, relativas ao círculo de convivência extrafamiliar dos adolescentes, como podemos observar no discurso judicial:

... está convivendo com pessoas de má índole, está identificado com o meio infracional. (5)

A Fundação CASA se detém com maior frequência à questão do círculo de convivência extrafamiliar dos jovens como meio argumentativo de seus discursos:

... o adolescente declarou que estava com uma dívida no valor de $\mathrm{R} \$$ 50,00, no dia da ocorrência foi procurado pelo colega Fulano e pressionado a pagar o referido valor, desta forma, decidiu traficar e assim quitar a dívida. (5)

Acerca de círculo de amizades, o adolescente verbalizou que se trata de um grupo mesclado, as nefastas são usuários de drogas, traficantes e alguns que praticam roubos. (5)

Segundo a Sra. Tal, o filho compareceu em três atendimentos técnicos no Posto de Liberdade Assistida, depois passou a apresentar resistência, devido influência das amizades. (5)

Quanto às amizades do adolescente, a genitora verbalizou que as nefastas são usuários de drogas. (5)

Transpareceu-nos que o adolescente tem envolvimento acentuado com o meio delitivo, que não se desvinculou do tráfico de entorpecentes e continuou com as mesmas amizades. (5)

... suscitou precocemente o acesso às amizades negativas. (5)

Observa-se que não valorizou a medida anteriormente aplicada, haja vista continuar com as mesmas escolhas, quanto às amizades, conduta de vida e uso contínuo de substâncias psicoativas de cannabis sativa que ocorre de forma frequente, desde seus doze anos de idade. (5)

Observamos estreitar às amizades de usuários de drogas, bem como em sua região de moradia há o acesso ao tráfico de entorpecente, mas aludiu-nos que devido o uso frequente afastou-se do tráfico por temer contrair dívida. (2)

o qual referiu amizades afeitas ao consumo de substância psicoativa e adquire tais substâncias através de seus amigos. "sic" (2)

Como podemos constatar, os discursos apresentam uma associação entre o círculo de amizades dos adolescentes e o seu envolvimento com substâncias psicoativas, estabelecendo uma relação de causalidade, na qual o envolvimento com essas 
substâncias (consequência) é gerado ou fomentado pela vinculação a determinadas amizades.

Essa explicação racional sobre a gênese do envolvimento com substâncias psicoativas apoiada no círculo de convivência é de caráter ideológico pela pretensão de dissociar a questão da convivência comunitária com a realidade social e histórica, concentrando o foco no âmbito individual e particular, como da ordem de uma escolha subjetiva dependente de concepções próprias, especialmente de cunho moral.

Assim, ao desconsiderar as condições sociais dos jovens, como a classe social a que pertencem e suas respectivas consequê4ncias econômicas, habitacionais, profissionais, culturais etc., os discursos atribuem aos próprios adolescentes, de forma individualizada, a responsabilidade pelas escolhas que os conduzem ao envolvimento com drogas.

\subsubsection{Competência}

A categoria empírica da competência diz respeito aos discursos referidos à “ideologia da competência”, rubrica que Chauí (2008) dá aos discursos produzidos pelos especialistas: sexólogos, nutricionistas, pediatras, psicólogos, pedagogos, sociólogos etc., que, segundo a autora, "nos ensinam a viver" (p. 111).

O discurso da ideologia da competência pretende fixar determinados modelos e padrões sociais por meio de ideias e valores considerados científicos. O discurso da competência procura encobrir a divisão social em classes afirmando que essa divisão se estabelece entre os competentes e os incompetentes, ou seja, entre os especialistas e os que acatam suas prescrições (Chauí, 2008).

Nos discursos judiciais, podemos observar a incorporação dos discursos da competência como apoio argumentativo para fundamentar suas decisões:

Além disso, consta no "relatório técnico inicial" da Fundação CASA que o adolescente não conta com "estrutura para conseguir cumprir medida em meio aberto ou de semiliberdade, tendo em vista sempre retornar às vias públicas e ao consumo de crack". A equipe técnica entendeu que a melhor medida a ser aplicada ao adolescente é a medida socioeducativa de internação, cumulada com tratamento para drogadição. (4) 
De acordo com o relatório técnico juntado aos autos, o adolescente está inserido em família desestruturada, não está estudando, faz uso de entorpecentes, vem praticando atos infracionais há algum tempo, está convivendo com pessoas de má índole, está identificado com o meio infracional. (5)

A ideologia da competência também aparece nos discursos judiciais como instâncias decisivas em face de demandas técnicas. Nessas circunstâncias, o discurso judicial declina ao saber institucionalizado dos especialistas a competência técnica e científica para tomar decisões.

Determino avaliação do adolescente junto ao CAPS-Sé, para avaliar se é necessária internação compulsória para tratamento de drogadição, especialmente no SAID. (4)

O discurso da ideologia da competência é mais presente nos discursos da Fundação CASA, tendo em vista a própria natureza técnica com que a instituição apresenta seus discursos, compilando pareceres técnicos de seus especialistas em diversas áreas do conhecimento, como podemos observar nas seguintes passagens:

Mediante o exposto, é visível a vulnerabilidade quanto ao uso de drogas sugerimos medida protetiva ao adolescente no CAPS AD e acompanhamento psicossocial para suscitar uma reflexão dentro de suas possibilidades quanto suas escolhas. (2)

Sugerimos ainda a inserção da genitora em grupo de apoio e orientação à família, a fim de prepará-la para desempenhar, de forma mais constante, papéis de autoridade e imposição de limites ao epigrafado. (2)

O jovem deverá ser conduzido à retomada do ensino formal, bem como encaminhamento ao CAPS AD para suscitar uma maior compreensão quanto ao prejuízo em seu contexto de vida. (2)

Avaliamos que para obtermos sucesso em seu tratamento, o mesmo poderia permanecer em regime de internação e ser encaminhado para frequentar o CAPS mais próximo de sua unidade de internação. (4)

...este técnico entende que o adolescente em questão necessita ser inserido em tratamento para drogadição de forma que esteja impedido de retornar as ruas neste momento de sua vida, até mesmo para que assim, paulatinamente, possam ser resgatados os vínculos necessários para sua reinserção familiar, que atualmente estão rompidos. (4)

...esta equipe técnica entende que o adolescente em questão necessita ser inserido em tratamento para drogadição de forma que esteja impedido de retornar as ruas. Somente sendo trabalhado prioritariamente este aspecto que outras áreas, como o retorno aos estudos de forma eficiente, serão assimilados pelo jovem. (4) 
Acreditamos que durante o período de internação, o adolescente poderá frequentar o CAPS AD mais próximo de sua unidade de internação. (4)

Perante o exposto, faz necessário o jovem ser estimulado por uma equipe multidisciplinar a desenvolver suas potencialidades e através dos atendimentos psicossociais estimulado a valorizar novas possibilidades de vida. (5)

Perante o exposto, faz necessária a intervenção sistemática em acompanhamento multidisciplinar a fim de estimular a novas possibilidades de vida como valorização e retorno ao núcleo escolar, inserção em cursos profissionalizantes, além de repensar efetivamente quanto ao caminho que buscou trilhar e nos reais prejuízos de vida. (5)

\subsection{Decisões judiciais de encaminhamento aos serviços de saúde mental}

Evidenciados os conteúdos ideológicos dos discursos judiciais, devemos agora nos deter às medidas judiciais de encaminhamento dos adolescentes aos serviços de saúde mental, que se apresentaram nas amostras com os seguintes pormenores:

- Primeira amostra: a decisão judicial contida na primeira amostra determinou a medida socioeducativa de Liberdade Assistida, pelo prazo de seis meses, cumulada com medida protetiva do artigo 101, inciso VI, do E.C.A. Nessa decisão, o juiz afirma expressamente que o deferimento da medida protetiva se deve ao requerimento da Defesa do adolescente, no qual há a indicação específica do CAPSad $^{31}$ como aparelho de saúde mental destinado ao tratamento do adolescente.

- Segunda amostra: na segunda amostra, a decisão é composta de medida socioeducativa de Semiliberdade sem prazo determinado e de medida protetiva do artigo 101, inciso VI, do E.C.A., constando expressamente na instrução processual que as partes: o Ministério Público e a Defensoria Pública acordaram no sentido de encaminhar o jovem para tratamento no CAPSad.

- Terceira amostra: a decisão contida na terceira amostra pesquisada homologa a remissão concedida pelo Ministério Público ao adolescente e comina a este medida protetiva do artigo 101, inciso V, do E.C.A. O juiz atribui em sua decisão que esta medida protetiva por ele decretada atende ao pedido feito pelo Ministério Público, que expressamente requereu o encaminhamento do adolescente para "tratamento psicológico".

\footnotetext{
${ }^{31}$ Centro de Atenção Psicossocial Álcool e Drogas.
} 
- Quarta amostra: a quarta amostra apresenta duas decisão judiciais relativas ao campo da saúde mental. A primeira delas foi tomada durante a instrução processual, na qual foi determinado o encaminhamento do adolescente ao CAPS-Sé "para avaliar se é necessária internação compulsória para tratamento de drogadição, especialmente no SAID”. Nessa decisão, o juiz requer o parecer da equipe técnica do CAPS da região Sé para decidir sobre a eventual internação compulsória do adolescente para o tratamento. Além disso, caso o parecer seja favorável à internação, a decisão indica expressamente o respectivo serviço de saúde mental para onde o adolescente deverá ser encaminhado, qual seja, para o $\mathrm{SAID}^{32}$. Na sentença judicial desta amostra, apresenta-se a segunda decisão de âmbito da saúde mental, consistente na aplicação ao adolescente da medida socioeducativa de Internação, sem prazo determinado, cumulada com medida protetiva do artigo 101, VI, do E.C.A. Nesta amostra, a Fundação CASA se manifesta no sentido de que o jovem "poderá frequentar o CAPS AD mais próximo de sua unidade de internação".

- Quinta amostra: a quinta e última amostra contém a decisão de aplicar ao adolescente o cumprimento da medida socioeducativa de Internação, sem prazo determinado, cumulada com "medida de tratamento para drogadição", do artigo 101, VI, do E.C.A. Nesta amostra consta que o adolescente, em sua audiência de apresentação, "concorda em tratamento para se livrar das drogas".

\footnotetext{
${ }^{32}$ SAID - Serviço de Atenção Integral ao Dependente - instituição ligada ao Hospital Samaritano com foco no tratamento de dependentes químicos.
} 


\section{DISCUSSÃo}

A partir do exame das decisões judiciais contidas nas amostras coletadas, podemos verificar, com exceção de uma amostra, a incidência de duas medidas judiciais simultâneas e distintas aplicadas sobre o mesmo adolescente: as medidas socioeducativas e as medidas protetivas. As primeiras são referidas à dimensão infracional, ou seja, estão afetas ao adolescente tomado enquanto adolescente em conflito com a lei. As medidas protetivas são concernentes ao adolescente considerado como sujeito de cuidados e de proteção ${ }^{33}$.

Podemos observar que a maioria das amostras apresentou como dispositivo legal para aplicação das medidas protetivas o inciso VI do artigo 101 do E.C.A., enquanto apenas uma amostra empregou o inciso $\mathrm{V}$ do mesmo diploma legal. A diferença entre esses dispositivos relaciona-se ao alcance do tratamento em saúde. Enquanto o inciso o VI destina-se especificamente ao tratamento em saúde mental de crianças e adolescentes usuários de substâncias psicoativas, o inciso $\mathrm{V}$ tem uma dimensão ampla, abrangendo a esfera da saúde no âmbito geral da medicina e da saúde mental, seja no campo da psicologia ou no campo da psiquiatria.

Outra consideração pertinente a essas amostras está relacionada à menção específica do serviço de saúde mental destinatário dos encaminhamentos. Constatamos que em três amostras há a indicação expressa do CAPSad (Centro de Atenção Psicossocial Álcool e Drogas) como o respectivo aparelho de saúde mental para onde os adolescentes devem ser encaminhados para tratamento. Na primeira amostra, o pedido expresso de encaminhamento ao CAPSad é feito pela Defensoria Pública. Já na segunda amostra, esse requerimento é realizado em consenso pelo Ministério Público e pela Defensoria Pública. A quarta amostra é referida ao CAPS expressamente pelo próprio juiz, ao requisitar uma avaliação, bem como pela equipe técnica da Fundação CASA.

As demais amostras (terceira e quinta) não especificam expressamente o serviço de saúde mental para o qual os adolescentes devem ser encaminhados. Todavia, podemos realizar algumas inferências a partir da análise contextual dessas amostras.

A terceira amostra apresenta a homologação do juiz em face dos requerimentos do Ministério Público: remissão e aplicação de medida protetiva do artigo 101, inciso V,

\footnotetext{
${ }^{33}$ Doutrina da proteção integral adotada no Estatuto da Criança e do Adolescente.
} 
do E.C.A. ${ }^{34}$. Esse dispositivo legal, que garante a possibilidade do juiz requisitar "tratamento médico, psicológico ou psiquiátrico, em regime hospitalar ou ambulatorial", aparece no requerimento do Ministério Público com a indicação expressa de que a medida protetiva consiste em "tratamento psicológico". Essa ressalva, além de excluir as possibilidades de que o tratamento seja médico ou psiquiátrico, pressupõe que o regime de tratamento não seja hospitalar em virtude do próprio exercício profissional da Psicologia. Ainda podemos inferir que o regime de tratamento não seja hospitalar em razão da manifestação do Promotor de Justiça no sentido de estimar que o uso de drogas feito pelo adolescente se trata de uma questão pontual e circunstancial: "O declarante não é viciado em crack, conhece as consequências nefastas da droga e não mais fará uso de drogas.".

A quinta amostra também não indica expressamente o serviço de saúde mental ao qual o jovem é destinado. No entanto, podemos identificar referências alusivas às características dos serviços do CAPS na manifestação técnica da "área psicológica" da Fundação CASA: "Perante o exposto, faz necessário o jovem ser estimulado por uma equipe multidisciplinar a desenvolver suas potencialidades e, através dos atendimentos psicossociais, estimulado a valorizar novas possibilidades de vida". Podemos notar ainda, que ao aplicar a medida socioeducativa de internação cumulada com medida protetiva, a decisão judicial não determina expressamente que o "tratamento para drogadição" seja feito em regime hospitalar, pressupondo-se que o adolescente permanecerá sob custódia na Fundação CASA e não em instituições hospitalares.

\subsection{Enfrentando a questão de pesquisa}

Frente à questão de pesquisa: as decisões judiciais no campo da saúde mental estão orientadas para o modelo de assistência psiquiátrica tradicional ou para o modelo de assistência proposto pela reforma psiquiátrica? E observando as três amostras (primeira, segunda e quarta) em que há a indicação expressa do CAPS como serviço de saúde mental destinado ao tratamento dos adolescentes, a resposta tenderia a

\footnotetext{
${ }^{34}$ Art. 101. Verificada qualquer das hipóteses previstas no art. 98, a autoridade competente poderá determinar, dentre outras, as seguintes medidas: V - requisição de tratamento médico, psicológico ou psiquiátrico, em regime hospitalar ou ambulatorial.
} 
corresponder ao modelo de assistência preconizado pelo movimento de Reforma Psiquiátrica, vez que o CAPS se constitui como dispositivo central da logística do serviço de saúde mental de rede comunitária, que se propõe como substituto aos serviços de saúde mental centrados no hospital psiquiátrico e na assistência psiquiátrica tradicional. No entanto, se nos detivermos mais atentamente à totalidade da espécie poderemos constatar que essa conclusão pode ser precipitada em função da aplicação de determinadas medidas socioeducativas em conjugação com o encaminhamento ao CAPS, de modo que devemos examinar a compatibilidade entre o cumprimento das medidas socioeducativas e o tratamento oferecido no CAPS, buscando verificar se este serviço conserva seu potencial e seu sentido dentro da lógica da rede comunitária de saúde mental para podermos responder à questão de pesquisa.

Analisando em primeiro lugar a medida socioeducativa de internação agregada ao encaminhamento ao CAPS (quarta amostra), constatamos desde logo a incidência de uma contradição entre essa medida privativa de liberdade e a lógica do CAPS como serviço de saúde mental em rede de base comunitária. Isso porque a aplicação da medida de internação interfere diretamente na dimensão do território do adolescente, não somente em decorrência da limitação espacial dada pelo regime de clausura próprio da medida de internação, mas em função do sentido social e simbólico conferido à concepção de território dentro da lógica da atenção psicossocial.

O conceito de território no âmbito da saúde mental em rede comunitária está ligado a uma noção integradora, não identificada somente como espaço natural nem apenas como espaço político, econômico ou cultural, mas considerada numa perspectiva totalizante dessas diferentes dimensões sociais. É nesse território integrado que as pessoas podem construir e exercer efetivamente o controle político e econômico e se apropriar dos recursos culturais (Haesbaert, 2004).

Esse conceito de território é fundamental para a compreensão do serviço em rede de saúde mental porque a própria rede comunitária pressupõe o território, de modo que falar em rede é, antes, falar em território. Isso significa que é a partir do território que a rede se organiza, propondo-se a substituir o serviço psiquiátrico tradicional (centrado no hospital psiquiátrico) por uma clínica ampliada de atenção psicossocial.

Nessa perspectiva de território relacional, material e simbolicamente integrado, o cumprimento da medida de internação se incompatibiliza com a lógica da rede de atenção comunitária do CAPS, proposta pela Reforma Psiquiátrica, vez que a internação 
(privação da liberdade) do adolescente o impede de se apropriar dos recursos e potenciais do território e de fortalecer seus laços familiares e comunitários, visando à reabilitação psicossocial.

Esse efeito restritivo e limitador imposto à dimensão do território dos adolescentes pela aplicação da medida de internação é denominado por Haesbaert (2004) de desterritorialização ou de territorialização precária. Segundo esse autor, a precarização territorial "deve ser aplicada a fenômenos de efetiva instabilidade ou fragilização territorial, principalmente entre grupos socialmente mais excluídos e/ou profundamente segregados" (p. 312).

Nesse sentido, a contradição entre a medida socioeducativa de internação e o tratamento no CAPS estabelece-se a partir do conceito de território, pois se por um lado o serviço de saúde mental em rede comunitária demanda da apropriação do território num sentido integrado, de outro lado, o adolescente internado vive num território precário, que o incapacita de se valer dos potenciais do território-rede no processo de reabilitação psicossocial. Essa contradição entre o território precário (do adolescente internado) e o território integrado (do serviço em rede do CAPS) restringe o tratamento de saúde mental à esfera meramente clínica e ambulatorial, realizada no interior do prédio do CAPS, configurando-se numa simples inclusão no CAPS e não numa inclusão no serviço de rede comunitária e atenção psicossocial proposto pelo CAPS.

Essa mesma contradição poderia recair também sobre a quinta amostra, que da mesma forma que a anterior, estabelece medida socioeducativa de internação cumulada com "medida de tratamento para drogadição" ${ }^{35}$. E dizemos poderia recair porque não há a indicação expressa do aparelho de saúde mental destinado ao tratamento do jovem, de modo que se o tratamento envolvesse a atenção psicossocial (e como mencionado, pressupusemos pelo contexto que sim), a contradição entre o território integrado da rede de atenção comunitária e a precarização do território do adolescente decorrente da medida de internação também se estabeleceria, constituindo-se como entrave essencial para o tratamento em saúde mental em rede comunitária.

Passando a analisar a conjugação entre a medida de semiliberdade com o encaminhamento ao CAPS (segunda amostra) observamos a mesma contradição entre a

\footnotetext{
${ }^{35}$ Parte do texto da sentença da quinta amostra: "Diante deste contexto entendo que deva ser aplicada ao adolescente a medida socioeducativa de internação cumulada com a medida de tratamento para drogadição."
} 
necessidade de um território integrado para a realização do serviço de saúde mental em rede e o território precário do adolescente em cumprimento de medida de semiliberdade, apesar do nível de precarização do território do adolescente ser menor do que a desterritorialização provocada pela medida de internação. Ou seja, a despeito do nível de precarização territorial do adolescente ser inferior no caso da medida de semiliberdade, vez que o adolescente tem o direito de sair durante o dia da instituição socioeducativa para realizar as atividades atinentes a seu programa individual de atendimento, o jovem permanece institucionalizado e desfalcado da territorialidade integrado, circunstância que arrefece o potencial do serviço em rede comunitária e atenção psicossocial do CAPS.

Com relação à cumulação entre medida de liberdade assistida e o tratamento no CAPS (primeira amostra), observamos não haver contradição com relação à territorialidade. Isso porque o regime aberto da medida socioeducativa de liberdade assistida não provoca a precarização do território integrado do adolescente, que está livre para se apropriar das potencialidades e dos recursos do território, assim como o território se apropriar de seus potenciais, numa relação dialética promovida pela rede de atenção psicossocial irradiada e organizada pelo CAPS.

Essa mesma conclusão vale para a terceira amostra se supusermos que o tratamento em saúde mental determinado pelo juiz deva ser realizado no serviço de estratégia de rede comunitária, pois nesta amostra não há cominação de qualquer medida socioeducativa, apenas a medida protetiva, "consistente em tratamento psicológico" ${ }^{36}$, de modo que a noção de territorialidade do adolescente não seria comprometida por medidas socioeducativas. Todavia, nesta amostra não há indicação expressa do respectivo serviço de saúde mental destinado ao adolescente (como mencionado anteriormente).

A partir dessa discussão das amostras, que resultou na identificação do território como elemento de contradição estabelecido na relação entre o tratamento em saúde mental e o cumprimento de determinadas medidas socioeducativas, podemos considerar

\footnotetext{
${ }^{36}$ Parte do texto da terceira amostra: "Assim, esta Curadoria concede a REMISSÃO como forma de exclusão do processo, conforme autoriza o disposto nos artigos 180, II e 201, I, ambos da Lei $\mathrm{n}^{\circ}$ 8.069/90, cumulada com medida protetiva do art. 101, inciso V, consistente em tratamento psicológico".
} 
que a resposta à questão de pesquisa está ligada à apreciação da esfera do território do paciente, condicionada pelo potencial desterritorializante de determinadas medidas socioeducativas, notadamente as medidas de internação e de semiliberdade. Além da análise do potencial do território do paciente, a resposta à questão de pesquisa impõe o conhecimento do dispositivo de saúde mental específico destinado ao tratamento dos adolescentes.

Com efeito, a resposta à questão de pesquisa depende da prévia avaliação do território do paciente e do conhecimento do respectivo serviço de saúde mental indicado para seu tratamento. Não há a possibilidade de assegurarmos uma resposta prévia à análise da perspectiva do território do paciente e do dispositivo de saúde mental específico, sob pena de incorrermos no equívoco de classificarmos uma decisão judicial orientada pelos paradigmas da Reforma Psiquiátrica considerando, por exemplo, que a mera inclusão no CAPS configure-se na inclusão no serviço de saúde mental em rede comunitária do CAPS.

Nesse contexto, podemos responder a questão deste estudo nos casos concretos contidos nas amostras que revelam o respectivo serviço de saúde mental de encaminhamento dos adolescentes, restando avaliar a perspectiva do território destes jovens para classificarmos a orientação teórico-assistencial do tratamento.

Como anteriormente mencionado, três das cinco amostras contém indicações expressas sobre o dispositivo de saúde mental específico para o tratamento dos jovens, condição que exclui as duas outras amostras (terceira e quinta amostras) da possibilidade de respondermos sobre o respectivo paradigma de orientação.

Com referência à territorialidade dos adolescentes das três amostras que especificaram o CAPS como o serviço de saúde mental destinado ao tratamento dos adolescentes, a segunda e terceira amostras aplicam medidas socioeducativas (semiliberdade e internação) que precarizam o território dos adolescentes pela institucionalização, enquanto que a medida socioeducativa da primeira amostra (liberdade assistida) preserva a territorialidade do jovem.

Com efeito, excluindo as amostras que não contemplam a indicação do serviço de tratamento em saúde mental, podemos afirmar que a primeira amostra encontra abrigo no paradigma da Reforma Psiquiátrica e as demais no paradigma da psiquiatria tradicional em função da inclusão dos adolescentes no CAPS não corresponder à 
inclusão dos jovens no serviço em rede de base comunitária organizado pelo CAPS, constituindo-se da mera inserção dos pacientes no CAPS.

\subsection{Leis e categorias do materialismo histórico-dialético}

As leis do materialismo histórico-dialético representam conexões internas essenciais entre os fenômenos, que os condicionam reciprocamente, de modo que na relação entre os fenômenos, a alteração de um deles determina a mudança no outro fenômeno. "As categorias da dialética encontram-se em estreita ligação com as suas leis básicas. As leis básicas da dialética exprimem-se e formulam-se unicamente através de certas categorias" (Konstantinov, 1975).

Neste estudo, refletiremos sobre as decisões judiciais contidas nas amostras à luz das leis e das categorias: causa e efeito e possibilidade e realidade, do materialismo histórico-dialético.

\subsubsection{Lei da unidade e luta dos contrários}

A lei da unidade e luta dos contrários atribui o desenvolvimento e a transformação dos objetos à luta entre os aspectos e tendências opostas e inerentes a todos os objetos e processos (Konstantinov, 1975).

Sob a perspectiva dessa lei podemos refletir sobre as amostras das decisões judiciais que apresentaram a contradição revelada na discussão deste trabalho, qual seja, a contradição no conceito de território, estabelecida na relação entre as medidas socioeducativas de internação ou de semiliberdade e os encaminhamento para tratamento no CAPS, referentes, respectivamente, a segunda e a quarta amostras.

Nessas amostras, as decisões judiciais, entendidas cada qual como uma unidade, possuem uma negação interna: o tratamento no CAPS enquanto dispositivo de saúde mental de rede comunitária e atenção psicossocial. Isso em virtude da desterritorialização provocada na esfera territorial dos adolescentes pelas medidas 
socioeducativas de internação e semiliberdade negarem o CAPS nesse sentido de serviço em rede.

Essa negação interna nas decisões judiciais desaparece se a territorialidade integrada do adolescente é preservada, como no caso da medida de liberdade assistida, constante da primeira amostra. Por outro lado, também não há que se falar em negação interna e, por conseguinte, em contradição, se a decisão judicial não estabelecer um serviço de saúde mental baseado em rede de atenção psicossocial, uma vez que algumas práticas psiquiátricas tradicionais são caracterizadas pela própria desterritorialização dos pacientes pela institucionalização, como nos casos de tratamentos realizados em hospitais psiquiátricos.

\subsubsection{Lei da negação da negação}

Essa lei "aparece como síntese de todo o desenvolvimento anterior, como síntese das formas unilateralmente contrárias, que supera e resolve as contradições entre elas." (Konstantinov, 1975, p. 170).

Como já salientamos anteriormente, a contradição de base territorial estabelecida nas decisões judiciais entre o tratamento em saúde mental no CAPS e as medidas socioeducativas de internação e semiliberdade nega o CAPS enquanto serviço de atenção psicossocial. Todavia, outra negação em face desta primeira (negação do CAPS) depende da negação da desterritorialização, podendo configurar-se no caso da aplicação da medida de liberdade assistida em cumulação com o tratamento neste dispositivo específico. Isso porque a medida de liberdade assistida, deixando de interferir no potencial da territorialidade do adolescente, compatibiliza-se com a lógica de serviço em rede comunitária do CAPS.

Com efeito, a negação da negação do CAPS (pelas medidas socioeducativas de internação e semiliberdade) depende da manutenção da territorialidade integrada, ou seja, da negação da desterritorialização, na hipótese de aplicação da medida socioeducativa de liberdade assistida em substituição ou progressão das medidas de internação e semiliberdade. 


\subsubsection{Lei da passagem de transformações quantitativas a qualitativas}

A qualidade de um fenômeno é indissociavelmente referida à determinada quantidade, tratando-se esta conexão e dependência como medida. As alterações da medida manifestam-se no movimento e nas mudanças dos fenômenos, que podem ser de natureza essencial, dependendo da intensidade dessa medida (Konstantinov, 1975).

Em relação a este estudo, parece-nos que a conexão interna e essencial presente na relação entre as medidas socioeducativas e as medidas de tratamento em saúde mental está ligada ao conceito de territorialidade.

Com efeito, a territorialidade é tomada como medida para a especificidade do paradigma do tratamento (pertinentes à reforma psiquiátrica ou à psiquiatria clássica). Ou seja, o componente quantitativo da territorialidade, expresso pela gradação ou intensidade da integração territorial do paciente, condiciona e determina a qualidade ou espécie do paradigma de tratamento em saúde mental. Dito de outra forma, quanto maior for a medida (quantidade) da territorialidade no sentido integrado, a qualidade (a espécie, o paradigma) do tratamento pode modificar-se em função da ampliação das propriedades territoriais, tidas como essenciais para a configuração do respectivo referencial teórico-assistencial.

\subsubsection{Categoria causa e efeito}

“Causa e efeito são conceitos correlativos. O fenômeno que dá origem a outro fenômeno é a causa deste. Causalidade é a conexão interna entre fenômenos, pela qual, sempre que um existe o outro se lhe segue inelutavelmente." (Konstantinov, 1975).

A desterritorialização ou precarização territorial provocada na esfera do território dos adolescentes pelas medidas socioeducativas de internação e semiliberdade produz efeitos no potencial do serviço em rede comunitária do CAPS dirigido a esses jovens. Por outro lado, a preservação da territorialidade integrada, pela aplicação de medida de liberdade assistida, por exemplo, produz efeito contrário, estabelecendo a compatibilidade com o serviço em rede de atenção psicossocial do CAPS. 
Assim, a territorialidade aparece como fio condutor entre causa e efeito. Dependendo da "carga" territorial, ou seja, da preservação ou da precarização do território dos adolescentes encaminhados para tratamento em dispositivos de atenção psicossocial, seguem-se consequências relativas à compatibilidade ou incompatibilidade com a proposta terapêutica destes dispositivos.

\subsubsection{Categoria possibilidade e realidade}

A correlação entre o possível e o real, do ponto de vista do materialismo histórico-dialético, está ligada ao processo de desenvolvimento e transformação dos fenômenos, "pois a possibilidade é uma das formas da realidade no sentido lato da palavra, como realidade interna, potencial.” (Konstantinov, 1975). No mesmo sentido, Cheptulin (1982) entende que "a realidade é o que existe realmente e a possibilidade é o que se pode produzir quando as condições são propícias".

Neste estudo, podemos entender como possível ou como possibilidade a adoção do paradigma proposto pela reforma psiquiátrica nas decisões judiciais. Isso porque a adoção deste paradigma se efetivou na realidade, na medida em que uma das amostras, configurada no plano material, demonstrou pelas observações e análises realizadas neste estudo a possiblidade de sua ocorrência. 


\section{SÍNTESE}

O exame das categorias empíricas da família, do círculo social e da competência, identificadas nas amostras deste trabalho, pôde representar as ideologias incorporadas às decisões judiciais, bem como as respectivas coerções ideológicas a que estas mesmas decisões são submetidas por parte dos discursos extrajudiciais a elas referidos. Todavia, o poder diretivo das decisões judiciais não se deve somente ao seu conteúdo ideológico, mas também decorre do poder inerente às leis nas quais as decisões se apoiam e do poder de que emana a própria instituição judiciária, ou seja, do poder do Estado na sua esfera jurídico-institucional: o Poder Judiciário ou o Estado-juiz.

Podemos observar que a face ideológica presente nas decisões judiciais reflete a aparência, a forma imediata e abstrata das questões envolvendo os adolescentes, encobrindo e afastando a compreensão da realidade de suas relações materiais de vida, que determinam a condição de desigualdade econômica, social, política e cultural desses jovens.

A contradição estabelecida entre o tratamento em saúde mental de atenção psicossocial e as medidas socioeducativas de internação e semiliberdade, referente à precarização da territorialidade dos adolescentes, revelou duas condições essenciais para a determinação do respectivo paradigma teórico-assistencial do campo da saúde mental, quais sejam, a avaliação da esfera territorial dos adolescentes e o conhecimento do específico dispositivo de saúde mental indicado para o tratamento dos jovens.

A omissão em analisar simultaneamente essas duas condições pode nos destinar a supor equivocadamente, por exemplo, que o tratamento oferecido pelo CAPS a um adolescente que esteja cumprimento medida socioeducativa de internação ou semiliberdade possa encontrar abrigo no referencial da reforma psiquiátrica, quando na verdade este jovem está meramente incluído no serviço clínico-ambulatorial prestado na sede do CAPS, não estando, portanto, inserido no serviço de rede comunitária de atenção psicossocial proposto pela reforma psiquiátrica ao dispositivo CAPS.

Com efeito, identificamos uma amostra $^{37}$, dentre as analisadas, que se configurou pertinente e conforme os preceitos da reforma psiquiátrica, vez que satisfez

\footnotetext{
${ }^{37}$ Primeira amostra: aplicação de medida socioeducativa de liberdade assistida cumulada com tratamento em saúde mental no CAPSad.
} 
os dois requisitos: nomeou o dispositivo específico de tratamento em saúde mental (CAPS) e aplicou uma medida socioeducativa (liberdade assistida), conjugada à protetiva, que não provocou a precarização territorial do adolescente, compatibilizandose com o serviço em rede comunitária de atenção psicossocial. 


\section{REFERÊNCIAS}

Amarante P. Loucos pela vida: a trajetória da reforma psiquiátrica no Brasil. $2^{\mathrm{a}}$ ed. Rio de Janeiro: Fiocruz; 1995.

Amarante P. Saúde mental e atenção psicossocial. 2a ed. Rio de Janeiro: Fiocruz; 2007.

Andery MA, Micheletto N, Sério TMP, Rubano DR, Moroz M, Pereira ME, et al. Para compreender a ciência: uma perspectiva histórica. 12a ed. São Paulo: Educ; 2003.

Barros S, Egry EY. O Louco, a loucura e a alienação institucional. Taubaté: Cabral; 2001.

Brasil. Código de processo civil. 24a ed. São Paulo: Saraiva; 1994.

Brasil. Constituição da república federativa do brasil. In Código de processo civil. 24 ed. São Paulo: Saraiva; 1994.

Brasil. Lei n. 8.069, de 13 de julho de 1990. Dispõe sobre o estatuto da criança e do adolescente. In Código de processo civil. 24a ed. São Paulo: Saraiva; 1994.

Brasil. Lei n. 10.216, de 06 de abril de 2001. Dispõe sobre a proteção e os direitos das pessoas portadoras de transtornos mentais e redireciona o modelo assistencial em saúde mental. Diário Oficial da União, Brasília, 09 abr. 2001. Seção 1, p.2.

Brasil, Ministério da Saúde. Reforma Psiquiátrica e política de saúde mental no Brasil. In: Conferência regional de reforma dos serviços de saúde mental: 15 anos depois de Caracas; 2005 nov. 07-10; Brasília, BR [citado 2011 jan. 31]. Disponível em: http://bvsms.saude.gov.br/bvs/publicacoes/Relatorio15_anos_Caracas.pdf

Brasil. Resolução 196, de 10 de outubro de 1996. Dispõe sobre diretrizes e normas regulamentadoras de pesquisas envolvendo seres humanos. Conselho nacional de saúde. Brasília, Ministério da Saúde; 1996. [citado 2012 jan. 08]. Disponível em: http://conselho.saude.gov.br/resolucoes/reso_96.htm

Chauí M. O que é ideologia. 2a ed. São Paulo: Brasiliense; 2008.

Cheptulin A. A dialética materialista. São Paulo: Alfa-Ômega; 1982. 
CURY M, coordenador. Estatuto da Criança e do Adolescente Comentado. $6^{\mathrm{a}}$ ed. São Paulo: Malheiros Editores; 2003.

Ferreira, $\mathrm{ABH}$. Minidicionário da língua portuguesa. $3^{\mathrm{a}}$ ed. Rio de Janeiro: Nova Fronteira; 1993.

Fiorin JL. Elementos de análise do discurso. 15ª ed. São Paulo: Contexto; 2011.

Fiorin JL. Linguagem e ideologia. $8^{a}$ ed. São Paulo: Ática; 2007.

Gil AC. Como elaborar projetos de pesquisa. $4^{\mathrm{a}}$ ed. São Paulo: Atlas; 2002.

Haesbaert RC. O mito da desterritorialização: do "fim dos territórios" à multiterritorialidade. Rio de Janeiro: Bertrand Brasil; 2004.

Konder L. O que é dialética. $20^{a}$ ed. São Paulo: Brasiliense; 1981.

Konstantinov FV. Fundamentos da filosofia marxista-leninista. Portugal: Novo Curso Editores; 1975. v.1.

Ludke M, André MEDA. Pesquisa em educação: abordagens qualitativas. São Paulo: EPU; 1986.

Malagodi E. O que é materialismo dialético. São Paulo: Brasiliense; 1988.

Marconi MA, Lakatos EM. Fundamentos de metodologia científica. $6^{\mathrm{a}}$ ed. São Paulo: Atlas; 2007.

Minayo MCS. O desafio do conhecimento: pesquisa qualitativa em saúde. $8^{a}$ ed. São Paulo: Hucitec; 2004.

Minayo MCS, Deslandes SF, Gomes R. Pesquisa social: teoria, método e criatividade. $27^{\mathrm{a}}$ ed. Petrópolis: Vozes; 2008.

Na rua, juiz vai avaliar menores da cracolândia. Folha de São Paulo. 2011 out. 4; Cotidiano: C6.

Netto J.P. O que é marxismo. 9ª ed. São Paulo: Brasiliense; 2006. 
Reuter Y. A análise da narrativa: o texto, a ficção e a narração. Rio de Janeiro: Difel; 2002.

São Paulo. Lei 10.241, de 17 de março de 1999. Dispõe sobre os direitos dos usuários dos serviços e das ações de saúde no Estado e dá outras providências. Diário Oficial do Estado de São Paulo, São Paulo, 18 de mar. 1999. Seção 1, v. 109, n. 51.

São Paulo. Lei Complementar n. 791, de 09 de março de 1995. Estabelece o Código de Saúde no Estado. Diário Oficial do Estado de São Paulo, São Paulo, 10 de mar. 1995. Seção 1, v. 105, n. 47.

Spinelli E. Kassab quer tirar à força viciado das ruas. Folha de São Paulo. 2011 jun. 21; Cotidiano: C8.

van Dijk TA. Discurso e Poder. $2^{\mathrm{a}}$ ed. São Paulo: Contexto; 2010. 


\section{APÊNDICE A - Primeira amostra}

Esta amostra se refere aos documentos do processo do ano de 2012, da tal Vara Especial da Infância e da Juventude de São Paulo, que versa sobre ato infracional, consistente em tráfico de drogas, atribuído ao adolescente tal, de 17 anos de idade. Constam nesta amostra, além do texto produzido pelo Juízo de Direito, documentos relativos aos textos produzidos pelo Ministério Público, pela Defensoria Pública, pela Polícia civil e pela Fundação CASA.

Texto do Juízo de Direito:

\section{VISTOS}

1. Adolescente representado pela prática de ato infracional descrito às fls. tais.

2. O representante do Ministério Público sugeriu a aplicação da medida de liberdade assistida, com o que concordam o adolescente, seu responsável e o Digno Defensor.

\section{DECIDO}

Diante da prática infracional admitida pelo adolescente e tendo em conta o amparo familiar, a sincera disposição de não mais infracionar e ainda a menor potencialidade ofensiva da conduta, creio que a medida consensualmente proposta é a que melhor atende aos desígnios do ECA.

4. Isto posto, JULGO PROCEDENTE a representação e aplico ao adolescente tal a medida de liberdade assistida, por seis meses. Aplico, também, a pedido da Defesa, a medida protetiva prevista no artigo 101, inciso VI do ECA. Encaminhe-se para cumprimento, sendo advertido o menor que o descumprimento injustificado da medida poderá implicar a imposição de medida de internação pelo prazo de até 03 (três) meses, na forma do artigo 122, inciso III, do ECA.

Iniciando a Análise do Discurso pelo patamar discursivo do percurso gerativo de sentido, ou seja, pela análise dos elementos dos níveis mais superficiais e concretos do discurso, verifica-se, sob o ponto de vista sintático, que o texto produzido pelo juiz apresenta um nível de revestimento narrativo predominantemente temático, tratando-se, portanto, de um discurso com função interpretativa.

Esse texto é elaborado em duas partes: na primeira, o discurso do juiz apresenta uma síntese produzida a partir da intertextualização dos discursos que integram o 
processo, produzidos pela Polícia, pelo Ministério Público, pela Defensoria Pública e pela Fundação CASA, dos quais foi enunciatário. Revestindo essa síntese de objetividade através do emprego da terceira pessoa do singular, proporciona um efeito de distanciamento, de neutralidade e de imparcialidade em relação aos discursos enunciados. Por meio desses procedimentos, o enunciador pressupõe como válidos e verossímeis os discursos anteriormente enunciados e em relação aos quais faz referências: "1. Adolescente representado pela prática de ato infracional descrito às fls. tais. 2. O representante do Ministério Público sugeriu a aplicação da medida de liberdade assistida, com o que concordam o adolescente, seu responsável e o Digno Defensor.".

A segunda parte é enunciada com efeito de sentido subjetivo pelo uso da primeira pessoa do singular e sinaliza ao enunciatário a introdução do ponto de vista do enunciador, que apresenta uma argumentação seguida de conclusão. A argumentação é composta por elementos próprios e por elementos derivados dos demais discursos presentes no processo. Estes se consubstanciam na reprodução da confissão do ato infracional pela figura do adolescente: "Diante da prática infracional admitida pelo adolescente", que é citada nos textos da Polícia, do Ministério Público e da Fundação CASA.

Como elementos próprios, observa-se que a argumentação é composta de uma avaliação positiva da figura da família do adolescente ("amparo familiar"); uma projeção da crença do enunciador na intencionalidade futura da figura do adolescente ("sincera disposição de não mais infracionar"); e na apreciação de baixa repercussão do ato infracional em si ("menor potencialidade ofensiva da conduta").

A conclusão do discurso enunciado pelo juiz atende os pleitos inscritos nos discursos do Ministério Público ("liberdade assistida, por seis meses") e da Defensoria Pública (medida protetiva prevista no artigo 101, inciso VI do ECA) e é justificada pelas temáticas do apreço à conciliação entre as partes e da reverência às leis (“... creio que a medida consensualmente proposta é a que melhor atende aos desígnios do ECA").

Nesse nível discursivo, mas sob a ótica semântica, o encadeamento figurativo cria um efeito de realidade que concretiza os temas da justiça, da família, da liberdade e da atenção à saúde, subjacentes ao enredo representacional do julgamento e da deliberação sobre a liberdade e o tratamento em saúde do jovem, levando-se em conta o "amparo familiar". 
Passando para o patamar narrativo de análise do texto produzido pelo juiz, constata-se que a narrativa, do ponto de vista semântico, trata da passagem de um estado de julgamento da figura do adolescente para um estado de sentenciamento. Já do ponto de vista sintático, há na narrativa o enunciado da passagem de um estado de conjunção da figura do adolescente com a expectativa para um estado de disjunção com ela e, simultaneamente, a passagem de um estado de disjunção com o atendimento em saúde para um estado de conjunção com ele.

No nível profundo ou fundamental da narrativa, a categoria semântica constituise pela oposição: atividade versus passividade, em decorrência das posições ativas e passivas estabelecidas na temática da justiça, da liberdade e da atenção à saúde e concretizadas pelas figuras discursivas. A figura do adolescente atuava no campo da atividade até o momento do julgamento, pois o fazia segundo sua própria vontade e responsabilidade, de maneira livre e autodeterminada. Ao ser submetido ao processo judicial, vê-se no campo da passividade pela sujeição às determinações e controles impostos pelas figuras de autoridades, tornando-se paciente também em relações aos profissionais de saúde.

Nesse sentido, a sintaxe do nível profundo da narrativa afirma a atividade ao expressar a liberdade e autodeterminação do adolescente até o momento de seu julgamento, nega essa atividade no momento em que o adolescente é submetido ao crivo judicial e afirma a passividade quando ao adolescente são aplicadas medidas socioeducativas e protetivas, mantendo-o submetido ao campo da passividade.

A qualidade da categoria semântica atividade é tratada nos discursos de forma disfórica (ou negativa), enquanto que a passividade é tida como eufórica (ou positiva). Isso porque as medidas aplicadas à figura do adolescente o mantém no domínio do controle institucional.

A presente amostra se fazia acompanhar de documentos oriundos do Ministério Público, da Defensoria Pública, da Polícia Civil e da Fundação CASA, que são a seguir reproduzidos e analisados em seus respectivos níveis discursivos.

\section{Ministério Público:}


Consta dos autos que, no dia tal, por volta das tantas horas, na rua tal, nesta cidade e comarca, o adolescente tal trazia consigo droga, sem autorização e em desacordo com determinação legal ou regulamentar.

Apurou-se que o adolescente encontrava-se no local dos fatos quando foi abordado por policiais militares. Efetuada revista pessoal no adolescente, foram localizadas em seu poder tantas porções de cocaína, tantas porções de maconha e tantas porções de crack, totalizando tanto de cocaína e tanto de "Cannabis sativa L", conforme laudo de constatação incluso. Questionado a respeito, o adolescente admitiu a prática do tráfico de drogas.

A confissão do adolescente, as circunstâncias da apreensão, a quantidade, a diversidade e a forma de acondicionamento das substâncias evidenciam que as mesmas se destinavam ao tráfico.

Trata-se desta feita, em tese, da prática do ato infracional previsto no art. 33, da Lei n ${ }^{\mathrm{o}} 11.343 / 2006$.

Devidamente cientificado da imputação que lhe é feita e que ora consta da representação, o adolescente foi ouvido informalmente, nos termos do artigo 179, do ECA. Na presença de sua genitora, o adolescente admitiu a prática do ato infracional.

Assim, com fundamento nos artigos 180, inciso III e 201, inciso II, ambos da Lei ${ }^{\circ}$ 8.069/90, REPRESENTO a V. Exa. o adolescente supramencionado, pretendendo a aplicação da medida socioeducativa prevista no artigo 112, inciso IV, LIBERDADE ASSISTIDA, pelo prazo de seis meses, e requeiro a instauração do devido procedimento legal, previsto no artigo 184 e seguintes, também do mesmo Estatuto.

Requeiro oficie-se ao D.P. de origem para que encaminhe o laudo definitivo das substâncias apreendidas.

No texto elaborado pelo Ministério Público, sob o ponto de vista da sintaxe discursiva, pode-se verificar que o enunciador, num primeiro momento, fazendo uso da terceira pessoa do singular e, atribuindo à polícia a responsabilidade pela autoria da narrativa ("Consta dos autos... Apurou-se que o adolescente... Questionado a respeito, o adolescente...”), pressupõe como o verdadeiro o seu conteúdo, reproduzindo-o para fins argumentativos: "A confissão do adolescente, as circunstâncias da apreensão, a quantidade, a diversidade e a forma de acondicionamento das substâncias evidenciam que as mesmas se destinavam ao tráfico". Por meio desses procedimentos textuais, o enunciador produz efeitos de realidade ao seu discurso. Num segundo momento, o enunciador finaliza o discurso fazendo requerimentos ao enunciatário com o uso da primeira pessoa do singular, o que confere subjetividade ao conteúdo petitório. Esse efeito subjetivo salienta a posição institucional do enunciador e a pertinência de sua intervenção diante dos argumentos previamente descritos em terceira e da primeira pessoa do singular na enunciação, projetando um efeito de sentido, respectivamente, 
objetivo e subjetivo ao enunciado. A princípio, ao falar em terceira pessoa, o enunciador descreve os fatos, as circunstâncias, as provas e a autoria, ressaltando um caráter de objetividade ao conteúdo argumentativo. Em seguida, o enunciador finaliza o discurso fazendo requerimentos em primeira pessoa, o que confere subjetividade ao conteúdo petitório. Esse efeito de sentido subjetivo projeta e salienta a posição institucional do enunciador e a pertinência de sua intervenção no processo.

\section{Defensoria Pública:}

De acordo.

Peço cumulação com medida do art. 101, VI, do ECA, para encaminhamento do jovem ao CAPS-AD.

Já o texto produzido pela Defensoria Pública se reporta ao texto do Ministério Público e, sem polemizar, enuncia um pedido ao enunciatário ("Peço cumulação com medida do art. 101, VI, do ECA, para encaminhamento do jovem ao CAPS-AD”), cuja justificativa ou fundamento não é explicitado no texto, mas é pressuposto pela intertextualidade, presente não apenas em relação ao discurso do Ministério Público, mas da Polícia e da Fundação CASA.

\section{Polícia Civil:}

Presente nesta Unidade Policial Judiciária os Policiais Militares Fulano e Sicrano noticiando que em patrulhamento de rotina pela área que abrange a circunscrição tal Distrito Policial, em local conhecido como ponto de tráfico de drogas visualizaram indivíduos em atitude suspeita e decidiram pela abordagem do mesmo.

Esclarece o condutor que o indivíduo foi surpreendido em uma viela e que este ao perceber a aproximação da guarnição policial, tentou empreender fuga jogando no chão uma pochete a qual estava em seu poder e continha em seu interior diversas porções de substâncias que se assemelham a cocaína, maconha e crack, bem como a quantia de $\mathrm{R} \$ 89,30$ em notas diversas.

Cumpre ressaltar que o conduzido identificou-se como adolescente tal e confessou a comercialização de drogas.

Conduzido a tal Central de Flagrante, foi providenciada a constatação das substâncias junto ao Instituto de Criminalística de onde retornaram com o laudo inicial $\mathrm{n}^{\mathrm{o}}$ tal e constatou a quantidade de tantos gramas para o item A, com resultado positivo para Cannabis Sativa L (maconha); tantos gramas para item B, com o resultado 
positivo para Cocaína; e tantos gramas para o item C, com o resultado positivo para Cocaína. Perita Criminal Beltrana.

$\mathrm{O}$ adolescente indagado sobre os fatos afirmou que vende drogas há dois dias no local; que vende a trouxinha de maconha por $\mathrm{R} \$ 5,00$ e a "pedra" por R\$ 10,00; que não tinha "farinha" para vender; que "trabalha" das 09:00 às 17:00 e ganha $\mathrm{R} \$ 30,00$ por dia.

Autoridade Policial após tomar ciência dos fatos determinou a lavratura da presente ocorrência versando sobre Tráfico de Entorpecentes.

Nos termos do art. 174 do ECA, considerando a gravidade do ato infracional e sua repercussão social, foi o adolescente encaminhado à Fundação Casa. Insta consignar que o curador, representante legal do adolescente, foi contatado pelos policiais desta unidade policial, telefone tal, porém, não se fez presente.

O texto da Polícia Civil descreve à temática da prisão através da figurativização da detenção de um adolescente acusado da prática de tráfico de drogas por policiais militares. No texto, o enunciador constrói uma narrativa linear, na qual fala na terceira pessoa do singular e remete às figuras dos policiais militares a responsabilidade pela veracidade do conteúdo da narração por meio do discurso indireto: "Presente nesta Unidade Policial Judiciária os Policiais Militares Fulano e Sicrano noticiando que (...) Esclarece o condutor que...”. Também mediante discurso indireto, o enunciador dá voz à figura do adolescente acusado (“... que afirmou que vende drogas há dois dias no local... que "trabalha" das 09:00 às 17:00 e ganha R\$ 30,00 por dia"), legitimando as ações dos policias militares e as próprias: “Autoridade Policial após tomar ciência dos fatos determinou a lavratura da presente ocorrência (...) considerando a gravidade do ato infracional e sua repercussão social, foi o adolescente encaminhado à Fundação Casa".

\section{Fundação CASA (Centro de Atendimento Socioeducativo ao Adolescente):}

Instrumental de coleta de dados do adolescente:

Situação familiar: residência fixa; pai vivo, com 89 anos de idade, aposentado, não convive com o adolescente; mãe viva, com 37 anos de idade, copeira, convive com o adolescente;

Situação escolar: $8^{\mathrm{a}}$ série do ensino fundamento;

Situação de saúde: nenhuma doença; usuário de drogas desde os 14 anos: maconha e solvente;

Situação de trabalho: não trabalha;

Vivência institucional: nenhuma 
Impressões Técnicas: adolescente relata que foi apreendido porque estava comercializando drogas. Entrevistado, informou-nos que os pais são separados e que reside com a mãe. Reside em casa alugada composta por cinco cômodos. Disse que não trabalha nem estuda. Refere-se ao relacionamento familiar como satisfatório.

O texto da Fundação CASA (Centro de Atendimento Socioeducativo ao Adolescente) é elaborado mediante discurso indireto, ao qual se imprime um efeito de realidade quando é apresentado como um diálogo realizado entre a instituição e o adolescente. Ao final, sob a rubrica "impressões técnicas", verifica-se que o conteúdo se trata do relato do adolescente ainda em discurso indireto e não de conteúdos atinentes a impressões subjetivas. 


\section{APÊNDICE B - Segunda amostra}

A presente amostra se refere aos documentos do processo do ano de 2011, que tramitou pela tal Vara Especial da Infância e da Juventude de São Paulo, versando sobre ato infracional, consistente em tráfico de drogas, atribuído ao adolescente tal, de 16 anos de idade. Constam nesta amostra, além do texto produzido pelo Juízo de Direito, os textos produzidos pela Fundação CASA e pela Defensoria Pública.

Textos do Juízo de Direito:

\section{Deliberação}

Deixo de acolher o pedido de liberação do adolescente. É que se trata de grave ato infracional correspondente ao crime de tráfico de entorpecentes. Dessa forma, é de se verificar que a quantidade de drogas apreendida bem indica que se tratava de mercancia. Portanto, em razão da gravidade do ato praticado, a liberação pretendida não pode ser acolhida. O crime de tráfico causa grande repercussão social, gerando intranquilidade aos cidadãos, justamente pela gravidade nele ínsita. Assim, conforme o art. 174 do ECA, a manutenção da apreensão deve ocorrer "pela gravidade do ato infracional e sua repercussão social", inclusive o adolescente possui passagem pela Fundação CASA, estando em descumprimento de medida de Liberdade Assistida. Dessa forma, decreto a internação provisória do adolescente.

Termo de audiência de apresentação

Declarações do adolescente: confessa a prática do ato infracional.

Encerramento da instrução e debates: as partes desistiram da produção de demais provas, o que foi homologado pelo MM. Juiz. Encerrada a instrução, passaram-se aos debates. As partes, após debates, requereram a procedência das representações com aplicação da medida socioeducativa de Semiliberdade, cumulada com a medida protetiva prevista no art. 101, inciso VI, do ECA, a ser cumprida no CAPS-AD.

\section{Sentença}

Tratam-se de imputações de ato infracional previsto no art. 33 da Lei 11.343/06. O adolescente admitiu a autoria. A materialidade de ambos os atos vieram aos autos. Estes elementos autorizam a procedência das imputações e permitem o julgamento de procedência com aplicação de medida de Semiliberdade, sem prazo determinado, com reavaliação a cargo do Juízo da Execução, cumulada com a medida protetiva prevista no art. 101, inciso VI, do ECA e consistente em inclusão em 
programa oficial ou comunitário de auxílio, orientação e tratamento a alcoólatras e toxicômanos.

Empregando a técnica de Análise do Discurso pelo componente sintático do nível discursivo sobre o texto do juiz intitulado "Deliberação", observa-se que o enunciador põe fim à polêmica sobre a liberação ou prorrogação da internação da figura do adolescente, prevalecendo a continuidade da apreensão. A fundamentação em prol da prorrogação é formulada pela mesma lei utilizada pela argumentação vencida ("conforme o art. 174 do ECA, a manutenção da apreensão deve ocorrer pela gravidade do ato infracional e sua repercussão social"). O texto produz efeitos de realidade ao ser elaborado com sentido subjetivo (uso da primeira pessoa do singular) e como uma "resposta" ao discurso da Defensoria Pública.

O texto chamado "Termo de audiência de apresentação" contém, num primeiro momento, o relato da figura do adolescente, que contempla a admissão de sua culpa. Num segundo momento, o discurso apresenta o relato das "partes", representadas pelas figuras do Ministério Público e da Defensoria Pública, que acordam uma proposta comum: "aplicação da medida socioeducativa de Semiliberdade, cumulada com a medida protetiva prevista no art. 101, inciso VI, do ECA, a ser cumprida no CAPSAD". O discurso desse texto é realizado em terceira pessoa do singular e se utiliza do discurso indireto para dar voz às figuras. Por meio desses expedientes, o discurso produz efeitos de realidade.

O último texto: "Sentença", reproduz o discurso anterior, contido no texto chamado "Termo de audiência de apresentação", com a diferença de ser enunciado de uma posição de poder decisória, conferida e legitimada pelas figuras discursivas. Nesse texto, o enunciador confirma implicitamente o acordo proposto no texto anterior, uma vez que a conclusão apresentada é equivalente à acordada pelas figuras das partes, embora textualizada de forma diversa: "medida de Semiliberdade, sem prazo determinado, com reavaliação a cargo do Juízo da Execução, cumulada com a medida protetiva prevista no art. 101, inciso VI, do ECA e consistente em inclusão em programa oficial ou comunitário de auxílio, orientação e tratamento a alcoólatras e toxicômanos".

Nesse mesmo patamar discursivo, porém, sob o ponto de vista semântico, observa-se a concretização de temas relativos à privação da liberdade, à justiça e à 
atenção em saúde, que são figurativizados pelo julgamento sobre a liberdade e sobre o tratamento em saúde da figura do adolescente.

Analisando o nível narrativo do discurso, o componente semântico trata da passagem de um estado de internação provisória da figura do adolescente (durante a fase do julgamento) para um estado definitivo de internação (pós-julgamento). Ainda analisando o nível narrativo, mas sob o ponto de vista da sintaxe, verifica-se a narrativa da passagem de um estado de conjunção da figura do adolescente com a expectativa de liberdade para um estado de disjunção com ela.

Passando para o nível fundamental, a narrativa lida com a categoria semântica: atividade versus passividade, tendo em vista a polarização entre agentes e paciente, dada pela situação de passividade da figura do adolescente perante as figuras de autoridade.

A atividade é referida na narrativa como de qualidade disfórica (negativa), ao passo que à passividade é atribuída qualidade eufórica (positiva). Isso em decorrência da decisão pela manutenção da figura do adolescente no âmbito do controle tutelar.

Esta amostra continha documentos provenientes da Fundação CASA e da Defensoria Pública, que são a seguir reproduzidos e submetidos à análise em seu patamar discursivo.

2. Fundação CASA:

Instrumental de coleta de dados do adolescente:

Situação familiar: residência fixa; pai vivo de paradeiro ignorado; mãe viva, com 38 anos de idade, profissão faxineira.

Situação escolar: interrompido na $4^{\mathrm{a}}$ série do ensino fundamento;

Situação de saúde: nenhuma doença; usuário de drogas desde os 15 anos: cocaína inalável e maconha;

Situação de trabalho: não trabalha; profissão: ajudante de pedreiro;

Vivência institucional: liberdade assistida; infração anterior: roubo. Impressões Técnicas:

Adolescente com passagem anterior pela Fundação CASA, reside com genitora e 4 irmãos em 1 cômodo com mínimo de infraestrutura básica. Irmãos: 16 anos, 13 anos, 10 anos e 18 anos.

Considera tranquilo o relacionamento familiar.

Adolescente evadiu-se da escola no ano de 2007 quando cursava a $4^{\mathrm{a}}$ série do ensino fundamental por falta de interesse.

Possui experiência laborativa de ajudante de pedreiro, lava-rápido. 
Faz uso de drogas ilícitas: maconha e cocaína com frequência.

Em relação ao delito nega ato infracional, sente-se injustiçado.

Relatório Técnico Inicial:

Vimos pelo presente encaminhar a Vossa Excelência informações pertinentes ao jovem em questão. $\mathrm{O}$ relatório foi fundamentado em pesquisa e análise em seu prontuário técnico, observações do comportamento do jovem nesta Unidade e atendimentos psicossociais do jovem.

Trata-se de um adolescente que consta com passagem anterior pela Fundação, ao analisarmos sua pasta social verificamos que em tal data foi agraciado com a medida socioeducativa de Liberdade Assistida.

O jovem procedeu nova entrada na data tal neste CASA pela prática da imputação do ato infracional versado em tráfico de entorpecentes, onde aguarda a prolatação da sentença.

Área social

O jovem discorre sobre seu histórico de vida demonstrando certa revolta quanto a sua situação de desenvolvimento familiar e socioeconômico, denotamos vários pontos negativos que estão interferindo na conduta apresentada pelo epigrafado.

A genitora expôs que na ocasião em que $o$ adolescente conheceu a figura paterna contava com dez anos de idade. O genitor abdicou em assumir as responsabilidades que the cabia, bem como não reconheceu a paternidade legalmente, bem como não representa para o filho uma figura positiva para seu desenvolvimento em virtude da envoltura deste no mundo criminal e ainda a dependência química. $O$ jovem não gosta de tecer comentário acerca do genitor, pois teve uma situação em que o tratou com certa indiferença.

Antecedente a sua apreensão, no âmbito familiar o pai do adolescente genitor estabelecia uma postura muito agressiva para com todos, pois a mãe do adolescente sofreu diversas vezes violência doméstica. Não o denunciava em virtude das ameaças sofridas pelo mesmo, posterior a uma violência sexual contra a mãe do adolescente, acarretou na sua apreensão nesta Capital.

A mãe do adolescente em 2008 foi apreendida e permaneceu durante 6 meses reclusa, foi acusada de tráfico de entorpecentes, visto que estava tentando adentrar com entorpecentes no sistema prisional, a mando do seu companheiro. Todavia os filhos ficaram sob os cuidados da progenitora materna e tia fulana.

A família vivencia situação socioeconômica desfavorável, quanto ao rendimento familiar vem do ofício da genitora que labuta como Ajudante de Limpeza em prédio residencial e percebe $\mathrm{R} \$ 545,00$ mensal, segundo o jovem os irmãos também labutam, todavia não sabe referir a função que exercem. A família está inclusa no Programa Social Bolsa Família e percebe a importância de R\$ 165,00.

A constelação familiar está organizada da seguinte forma: genitora: 38 anos; irmão: 22 anos; irmão: 21 anos; prima: 13 anos de idade, cursa a 
$6^{\mathrm{a}}$ série do ensino fundamental; primo: 10 anos de idade, cursa a $4^{\mathrm{a}}$ série do ensino fundamental; irmã: 18 anos de idade; irmão: 16 anos de idade.

Elucidou que o irmão Fulano encontra-se recluso há 2 anos devido envolvimento com comercialização de entorpecentes. $O$ referido irmão, o Cicrano e o Beltano são usuários de substância química.

Pertinente a situação habitacional denota que a infraestrutura é precária pois no mesmo quintal existem nove residências habitadas somente por familiares. A moradia da família é composta por um quarto, cozinha e banheiro e comporta sete pessoas.

No âmbito pedagógico, o jovem evadiu-se do estabelecimento de ensino quando cursara a $4^{\mathrm{a}}$ série do ensino fundamental. $\mathrm{O}$ jovem contava com 8 anos de idade quando manifestou comportamento instável e agressivo no equipamento escolar, quando então a genitora não conseguindo sanar esta problemática buscou respaldo no Conselho Tutelar, do qual foi encaminhado para psicoterapia dor duas vezes, no entanto, o jovem não aderiu ao tratamento. Após a prisão da genitora o epigrafado abandonou o estudo e começou a usar entorpecentes.

$O$ adolescente contava com 9 anos de idade quando começou a vincular-se as amizades nefastas e praticar furtos, quanto ao consumo de drogas o jovem não consegue avaliar acerca dos detrimentos que culmina para sua vida, apresentou discurso com pouca veracidade concernente ao consumo de substância química da cocaína. A genitora ressaltou que no âmbito familiar o jovem não acata suas determinações, não tem escuta, se comporta de maneira displicente e por vezes se mostra irritadiço e agressivo.

Quando o padrasto estava presente no seu âmbito familiar desencadeava uma dinâmica desarmônica e o adolescente não suportando estas situações conturbadas e agressivas que este manifestava para com todos os membros até mesmo com seus filhos biológicos, preferia perambular na rua com seus colegas.

Salientamos que o jovem é proveniente de uma dinâmica adoecida percebemos que não está sob ação suficiente de referencial familiar de autoridade, pois $o$ adolescente vem conduzindo a vida sob sua própria ótica e ainda com comprometimento em substância química. A genitora necessita de instrumentos de apoio e orientação para que possa zelar mais atentamente pelo acompanhamento e as demandas trazidas pelo filho.

\section{Área Psicologia}

O presente relatório utilizou instrumentais de consulta a pasta social, atendimentos psicossociais individualizados ao adolescente $\mathrm{e}$ encaminhamento à avaliação psiquiátrica.

Sua estrutura psíquica apresentou-se orientado no tempo e espaço, com certo prejuízo na memória de fixação e evocação; atenção e humor sem alterações. Referiu uso frequente de substância psicoativa de cocaína e cannabis sativa, o qual não soube declinar o tempo além de denotar prejuízo na aprendizagem; não é alfabetizado e inteligência 
está na faixa inferior da normalidade, conforme avaliação psiquiátrica anterior.

Trata-se de um adolescente de 16 anos de idade e onze meses, com histórico de vida em que observamos referenciais fragilizados de figura parental.

O adolescente é fruto de um relacionamento efêmero, o qual não foi reconhecida a paternidade e teve um único contato aos dez anos de vida e a genitora manteve o adolescente distanciado do pai biológico devido envolvimento por drogas e práticas ilícitas por um período.

$\mathrm{Na}$ estrutura familiar contou com um padrasto e presença intermitente, haja vista ter passado pelo sistema prisional, bem como chegou a ficar sob os cuidados da progenitora materna por seis meses em 2008 culminando pela prisão de sua responsável devido entrar na penitenciária com entorpecentes para o padrasto.

$\mathrm{O}$ adolescente esclareceu que sua genitora não mantém mais contato com o referido padrasto.

Conforme dados da pasta social, apresentou desde tenra idade dificuldades diversas, suscitado por violência doméstica relacionada à figura do padrasto, prejuízos em seu autocontrole que o levaram a impulsividade e instabilidade afetiva, o qual chegou a realizar acompanhamento psiquiátrico na infância.

Durante a entrevista neste Centro denotou muita dificuldade em expor a rotina familiar, além de não recordar sobre alguns fatos e dificuldade em situar no tempo ocorrido.

Sugeriu que o núcleo familiar fragilizado de figura de autoridade e referencial positivo neste processo de formação de identidade; puderam suscitar a vulnerabilidade quanto à influência negativa, além de denotar uma criticidade pouco elaborada em detrimento de seu histórico de vida e aspecto cognitivo.

Observamos estreitar às amizades de usuários de drogas, bem como em sua região de moradia há o acesso ao tráfico de entorpecente, mas aludiu-nos que devido o uso frequente afastou-se do tráfico por temer contrair dívida.

Denotou dificuldade de vislumbrar a necessidade de intervenção à drogadição e manifestou autocontrole prejudicado para cessar ou diminuir o uso e encontra-se conforme análise do teste ASSIST, fase de pré-contemplação, o qual ainda requer sensibilização para um acompanhamento.

Observamos que o uso abusivo de substâncias psicoativas poderá interferir em sua determinação a uma projeção futura $\mathrm{e}$ responsabilidade para consigo, bem como não cumpriu a medida anteriormente aplicada de Liberdade Assistida. Para tanto, encaminhamos ao instituto tal para acompanhamento psiquiátrico.

Quanto ao ato infracional que gerou sua entrada, o adolescente negou seu envolvimento em tráfico de entorpecente, bem como situação de risco no tráfico, o qual referiu amizades afeitas ao consumo de substância psicoativa e adquire tais substâncias através de seus amigos. "sic" 
Mediante o exposto, é visível a vulnerabilidade quanto ao uso de drogas sugerimos medida protetiva ao adolescente no CAPS AD e acompanhamento psicossocial para suscitar uma reflexão dentro de suas possibilidades quanto suas escolhas.

\section{Área pedagógica}

$O$ adolescente em entrevista inicial pedagógica informou que parou de estudar na $4^{\text {a }}$ série do ensino fundamental, tendo desmotivado-se a continuar os estudos devido a zombarias feitas pelos colegas de escola quanto ao seu analfabetismo. As informações relativas à escolarização foram confirmadas em pesquisa realizada pela PRODESP.

Com o objetivo de obtermos maiores dados quanto às habilidades de leitura, escrita e matemática básica e, para colocarmos em prática eventual intervenção pedagógica, caso seja necessária, o jovem realizou o Diagnóstico de Escrita, Leitura e Matemática. Segundo os resultados obtidos o adolescente é analfabeto. Em matemática, realiza algumas operações envolvendo as 4 operações básicas.

Neste período, em que se encontra no CASA tal o adolescente foi inserido em atividades de pintura, desenho, grupos terapêuticos, oficinas paralelas e projetos desenvolvidos pelo setor pedagógico. Agora o adolescente está cursando o módulo "Trabalho em nossas vidas" do PEC - Programa de Educação e Cidadania, promovendo uma reflexão sobre o papel do trabalho na sociedade contemporânea.

O jovem também está inserido nas Oficinas do PEC, que incluem atividades lúdicas, físicas, rodas de leitura, exibição de filmes e vídeos educativos, que compreendem as Oficinas de Correspondência, Artes visuais e cênicas, Educação ambiental, Ponto de Encontro e Contos, Jogos da vida, Jornal, Música e movimento e Hora de se mexer, subdivididas em vários temas pertinentes aos assuntos relacionados.

$\mathrm{O}$ adolescente foi informado sobre o trabalho voluntário desenvolvido em parceria com o PAR - Programa de Assistência Religiosa neste centro, caso tenha interesse em assistir às palestras ministradas por diversas entidades religiosas.

Com relação às atividades de arte e cultura o adolescente está realizando as atividades de jogos lúdicos, competitivos e recreativos, onde trabalha a criatividade. Estas atividades são realizadas em parceria com o setor pedagógico desta casa.

Em relação à experiência profissional afirma que já trabalhou em lavarápido e como ajudante de pedreiro. Informou que gostaria de fazer o curso de informática e de edificações caso tenha esta oportunidade.

Em seu período neste Centro, o adolescente tem se mostrado respeitador das regras comportamentais estabelecidas e tem se esforçado para realizar os trabalhos propostos em sala de aula. Nada consta que o desabone no período em que se encontra nesta casa. Entende o quanto a continuidade dos estudos é importante para a inserção no mercado de trabalho e que a aprendizagem ocorre em todos os espaços frequentados, levando com isso a apropriação dos novos conhecimentos que lhe serão úteis ao longo de sua vida. 
Área de segurança

Desde que se somou à população deste Centro, o adolescente foi orientado quanto ao cumprimento das normas e regras desta Instituição. Até a presente data, encontra-se diante de conduta adequada, não há nada que desabone o proceder do jovem.

Sugestões de Acompanhamento

Diante do exposto, sugerimos a inserção em acompanhamento psicossocial, a fim de que reflita dentro de suas possibilidades quanto aos prejuízos de suas escolhas e amizades.

Sugerimos ainda a inserção da genitora em grupo de apoio e orientação à família, a fim de prepará-la para desempenhar, de forma mais constante, papéis de autoridade e imposição de limites ao epigrafado.

O jovem deverá ser conduzido à retomada do ensino formal, bem como encaminhamento ao CAPS AD para suscitar uma maior compreensão quanto ao prejuízo em seu contexto de vida.

Sendo o que tínhamos a informar, encaminhamos o presente para apreciação e decisão judicial.

O texto da Fundação CASA intitulado "Instrumental de coleta de dados do adolescente" apresenta, num primeiro momento o relato da figura do adolescente apresentado no texto sob a aparência de entrevista, com perguntas e respostas. Esse efeito de realidade é produzido pelo uso do discurso indireto, pela terceira pessoa do singular e pela organização estilística do texto. Num segundo momento, o enunciador continua o relato da figura do adolescente, apesar de atribuir ao discurso o título de “impressões técnicas”.

Já o texto da Fundação CASA chamado "Relatório Técnico Inicial” é composto de um preâmbulo e de diversos tópicos. No preâmbulo, constata-se a projeção de censura e reprovação à figura do adolescente, que não teria sido digno da medida a ele anteriormente aplicada, considerada como uma graça: "Trata-se de um adolescente que consta com passagem anterior pela Fundação, ao analisarmos sua pasta social verificamos que em tal data foi agraciado com a medida socioeducativa de Liberdade Assistida".

O texto presente no tópico chamado "Área Social" apresenta um discurso que identifica causas que explicam a situação de vida da figura do adolescente ("denotamos vários pontos negativos que estão interferindo na conduta apresentada pelo epigrafado"). O enunciador reconhece a figura do pai do adolescente como uma das 
causas: "O genitor abdicou em assumir as responsabilidades que lhe cabia, bem como não reconheceu a paternidade legalmente, bem como não representa para o filho uma figura positiva para seu desenvolvimento em virtude da envoltura deste no mundo criminal e ainda a dependência química". O enunciador também atribui à figura da mãe do adolescente as causas de sua condição atual: "Após a prisão da genitora o epigrafado abandonou o estudo e começou a usar entorpecentes". Também identifica como causas, as relações com o padrasto ("Quando o padrasto estava presente no seu âmbito familiar desencadeava uma dinâmica desarmônica") e com amigos ( $O$ adolescente contava com 9 anos de idade quando começou a vincular-se as amizades nefastas e praticar furtos"). O discurso é encerrado com a conclusão de que a figura da mãe deva receber suporte: “A genitora necessita de instrumentos de apoio e orientação para que possa zelar mais atentamente pelo acompanhamento e as demandas trazidas pelo filho".

Quanto à parte do texto "Área Psicologia", tem-se um discurso argumentativo e conclusivo sobre a figura do adolescente. A argumentação é composta pelos seguintes recursos: relato do adolescente por discurso indireto, resultados de teste psicológico e consulta a outros documentos. Todos esses recursos e o uso da terceira pessoa do singular produzem efeitos de realidade ao texto. O discurso propõe ao enunciatário o encaminhamento da figura do adolescente para tratamento em instituição determinada: “... sugerimos medida protetiva ao adolescente no CAPS AD e acompanhamento psicossocial para suscitar uma reflexão dentro de suas possibilidades quanto suas escolhas”. Essa conclusão é fundamentada em torno do círculo social da figura do adolescente e do consumo de drogas: “... observamos referenciais fragilizados de figura parental"; "Sugeriu que o núcleo familiar fragilizado de figura de autoridade e referencial positivo"; "Observamos estreitar às amizades de usuários de drogas..."; “Observamos que o uso abusivo de substâncias psicoativas poderá interferir em sua determinação a uma projeção futura e responsabilidade para consigo..."; "referiu amizades afeitas ao consumo de substância psicoativa e adquire tais substâncias através de seus amigos. "sic"”.

O texto da Fundação CASA segue para a chamada "Área Pedagógica”, que se apresenta como uma narração sobre a figura do adolescente no âmbito escolar. O texto expressa sentido de objetividade ao falar na terceira pessoa do singular, usar o discurso indireto e explorar dados relativos a testes pedagógicos. O discurso é concluído pelo 
enunciador com o reconhecimento dos esforços realizados pela figura do adolescente, bem como relativos ao seu comportamento moral.

A parte do texto chamada "Área de Segurança" concretiza os temas da obediência e da adaptação por meio da narração descritiva de comportamentos e atitudes da figura do adolescente, considerados satisfatórios na ótica do enunciador: "Até a presente data, encontra-se diante de conduta adequada, não há nada que desabone o proceder do jovem".

A sessão "Sugestões de Acompanhamento" finaliza o texto da Fundação CASA. Nesse momento, o enunciador apresenta conclusões baseadas nos argumentos dispostos nos tópicos ("áreas") anteriores, declinando-as de forma sugestiva e imperativa por meio do uso do modo verbal indicativo ("sugerimos a inserção em acompanhamento psicossocial..."; "Sugerimos ainda a inserção da genitora em grupo de apoio e orientação à família...”) e do modo verbal imperativo (“O jovem deverá ser conduzido à retomada do ensino formal, bem como encaminhamento ao CAPS AD para suscitar uma maior compreensão quanto ao prejuízo em seu contexto de vida").

3. Defensoria Pública:

O Ministério Público opinou pela internação provisória. Ocorre que entendemos ser absolutamente desnecessária a custódia cautelar do adolescente. Ora, não está demonstrada a imperiosidade da medida; ao contrário, as circunstâncias do caso concreto demonstram que a internação pode ser ainda mais danosa ao adolescente.

Ao adolescente está sendo imputado ato infracional praticado sem violência ou grave ameaça à pessoa. Assim, suas internações não estão autorizadas por lei, vez que o rol do art. 122 o ECA é taxativo e somente permite a internação em casos de ato praticado mediante violência ou grave ameaça, reiteração de outros atos graves e descumprimento de medida anterior. Assim, por falta de fundamento legal, requer seja indeferido o pedido de internação provisória, com entrega imediata à família.

O enunciado presente no texto da Defensoria Pública se dirige ao enunciatário reportando-se à opinião da figura do Ministério Público, em relação à qual se opõe, polemizando a questão da internação da figura do adolescente. A contra-argumentação do discurso tematiza a injustiça, concretizada na argumentação de violação dos direitos estabelecidos em lei. Manifestam-se nesse texto os seguintes efeitos estilísticos: no 
primeiro momento, o enunciador atrai o enunciatário ao discurso pelo uso da primeira pessoa do plural: "Ocorre que entendemos...". No segundo momento, valendo-se do texto legal (“... do art. 122 do ECA") o enunciador insta o enunciatário a zelar pelo cumprimento das leis. 


\section{APÊNDICE C - Terceira amostra}

Os documentos desta amostra se referem ao processo do ano de 2010, que tramitou pela tal Vara Especial da Infância e da Juventude de São Paulo, versando sobre ato infracional, consistente em porte de drogas para consumo pessoal, atribuído ao adolescente tal, de 14 anos de idade. Constam nesta amostra, além do texto oriundo do Juízo de Direito, o texto produzido pelo Ministério Público.

Texto do Juízo de Direito:

VISTOS

HOMOLOGO, por sentença, para que produza seus jurídicos e legais efeitos, a REMISSÃO COMO FORMA DE EXLUSÃO DO PROCESSO, cumulada com medida protetiva prevista no artigo 101, inciso V, do ECA, concedida pelo d. representante do Ministério Público relativo ao adolescente tal com fundamento no art. 181 da Lei 8.069/90, providenciando-se o necessário.

Após o trânsito em julgado arquivem-se os presentes autos.

A partir do nível discurso, a análise do componente sintático permite observar que o discurso presente no texto do juiz confirma na totalidade o discurso da figura do Ministério Público e é produzido com efeitos de realidade decorrentes do emprego da primeira pessoa do singular (eu) e pela flexão temporal dos verbos no presente (agora).

Prosseguindo na análise do patamar discursivo, mas sob o olhar do componente semântico, verifica-se que o percurso figurativo concretiza os temas da justiça e da atenção à saúde, na medida em que o enredo relaciona-se ao julgamento da figura do adolescente infrator e seu encaminhamento para "tratamento psicológico".

Analisando o nível narrativo do percurso gerativo de sentido, observa-se que a semântica narrativa trata da passagem do adolescente de um estado sem atendimento em saúde mental para um estado de atendimento psicológico. Com relação à sintaxe narrativa, verifica-se a passagem de um estado de disjunção do jovem com o tratamento psicológico para um estado de conjunção com ele.

O patamar profundo do nível narrativo dos discursos expõe a semântica fundamental baseada no modelo invariante: atividade versus passividade, em 
decorrência da dinâmica dos estados ativo e passivo constituírem a base da narrativa ao vincular a figura do adolescente às figuras de autoridade, instalando posições de subordinação e de determinação respectivamente.

A categoria semântica atividade versus passividade apresenta qualidade eufórica em relação à passividade e qualidade disfórica relativamente à atividade. Isso em razão da avaliação positiva conferida à posição passiva, demonstrada nos discursos pela aplicação de medida protetiva à figura do adolescente, que o mantém vinculado ao controle das figuras institucionais.

Esta amostra dispunha do documento de origem do Ministério Público, a seguir reproduzido e analisado à luz do patamar discurso.

Texto do Ministério Público:

No dia $\mathrm{tal}$, o adolescente $\mathrm{tal}$ supramencionado compareceu perante o representante do Ministério Público, acompanhado de sua genitora. Confessa a prática do ato infracional, passou a fazer consumo de crack há pouco tempo, tendo em vista que está enfrentando dificuldades em lidar com a genitora, que está com vários problemas de saúde (AIDS e câncer). $\mathrm{O}$ declarante não é viciado em crack, conhece as consequências nefastas da droga e não mais fará uso de drogas.

Assim, esta Curadoria concede a REMISSÃO como forma de exclusão do processo, conforme autoriza o disposto nos artigos 180, II e 201, I, ambos da Lei $n^{\circ} 8.069 / 90$, cumulada com medida protetiva do art. 101, inciso $V$, consistente em tratamento psicológico.

Aguarda-se a homologação.

O texto do Ministério Público produz um efeito de sentido objetivo ao discurso, pois é elaborado integralmente com uso de terceira pessoa do singular. O enunciador dá voz à figura do adolescente através do discurso indireto, enunciando asserções do presente (agora) e do futuro (não agora). As primeiras dizem respeito a pormenores do jovem e de sua relação com a mãe, que ocorrem no presente: "passou a fazer consumo de crack há pouco tempo"; "está enfrentando dificuldades em lidar com a genitora, que está com vários problemas de saúde (AIDS e câncer)". A asserção futura é atinente à abstinência do uso de drogas pela figura do adolescente no futuro, cuja crença do enunciador é explicitada no seguinte trecho do enunciado: "conhece as consequências nefastas da droga e não mais fará uso de drogas”. Nesse procedimento, o enunciador atribui à figura do adolescente a assunção de uma promessa, cujo descumprimento 
confere ao mesmo enunciador o direito de reclamar a realização do compromisso assumido. 


\section{APÊNDICE D - Quarta amostra}

Os documentos colhidos nesta amostra se referem ao processo do ano de 2012, que tramitou pela tal Vara Especial da Infância e da Juventude de São Paulo, versando sobre ato infracional, consistente em tráfico de drogas, atribuído ao adolescente tal, de 17 anos de idade. Constam nesta amostra, além dos textos produzidos pelo Juízo de Direito, os textos elaborados pela Fundação CASA, pelo Ministério Público e pela Defensoria Pública.

Textos do Juiz de Direito:

Termo de Audiência de Instrução, Debates e Julgamento.

ENCERRAMENTO DA INSTRUÇÃO E DEBATES: As partes apresentaram debates, que foram colhidos em termo apartado, tendo o Ministério Público requerido, preliminarmente, a juntada aos autos do laudo de exame químico toxicológico.

DELIBERAÇÃO: Observado o prazo da internação provisório, converto o julgamento em diligência para determinar que se cobre a remessa do laudo de exame químico toxicológico. Cobre-se, também, a remessa do relatório inicial do adolescente, no prazo de 48 horas. Determino avaliação do adolescente junto ao CAPS-Sé, para avaliar se é necessária internação compulsória para tratamento de drogadição, especialmente no SAID. Oficie-se a Fundação CASA para que encaminhe ao CAPS-Sé a fim de realizar tal avaliação. Com a juntada deste aos autos, vista às partes para manifestação voltando-me, após, conclusos para sentença. Saem os presentes intimados.

\section{Sentença}

A materialidade do ato infracional está devidamente comprovada nos autos. Por sua vez, a autoria está devidamente comprovada. Considerando as declarações das testemunhas bem como o local onde o adolescente foi apreendido ("ponto de tráfico"), a quantidade e a forma de acondicionamento dos entorpecentes, a quantia em dinheiro encontrada ("trocado"), dúvida não há quanto à prática do ato que lhe é imputada, impondo-se a procedência da ação.

Verifica-se que o adolescente é reincidente, já tendo recebido medida socioeducativa de semiliberdade, a qual descumpriu.

Além disso, consta no "relatório técnico inicial" da Fundação CASA que o adolescente não conta com "estrutura para conseguir cumprir medida em meio aberto ou de semiliberdade, tendo em vista sempre retornar às vias públicas e ao consumo de crack". A equipe técnica entendeu que a melhor medida a ser aplicada ao adolescente é a 
medida socioeducativa de internação, cumulada com tratamento para drogadição.

Ressalte-se que o adolescente consome crack continuamente bem como há 06 anos iniciou a prática de furtos e de tráfico de entorpecentes. Além disso, o adolescente não conta com qualquer respaldo familiar, sendo que está fora do convívio familiar há bastante tempo.

Diante desse contexto subjetivo e objetivo, entendo que deve ser aplicada ao adolescente a medida socioeducativa de internação, cumulada com a medida protetiva de tratamento para drogadição.

Ante o exposto, confirmo a internação provisória e com base no art. 112, VI e art. 101, VI do ECA, julgo procedente a imputação a medida socioeducativa de internação por prazo indeterminado, porém, constitucionalmente breve, com relatórios trimestrais, cumulada com a medida protetiva de inclusão em programa oficial ou comunitário de auxílio, orientação e tratamento a alcoólatras e toxicômanos.

Procedendo à Análise do Discurso a partir do componente sintáxico do nível discursivo, verifica-se que o texto do juiz intitulado "Termo de Audiência de Instrução, Debates e Julgamento", divide-se em duas partes. Na primeira parte o texto é produzido com efeitos de objetividade (terceira pessoa do singular e flexão do tempo verbal no passado) e descreve a ocorrência dos debates entre as figuras do Ministério Público e da Defensoria Pública. A segunda parte apresenta considerações referentes à polêmica estabelecida pelas referidas figuras e, com efeitos de subjetividade (uso da primeira pessoa do singular e do tempo verbal presente) o enunciador concretiza a temática da dúvida ao determinar providências prévias à sua conclusão: "Determino avaliação do adolescente junto ao CAPS-Sé, para avaliar se é necessário internação compulsória para tratamento de drogadição, especialmente no SAID”.

O texto do juiz chamado "Sentença" põe fim à dúvida que restava à figura do julgador e, reproduzindo o discurso da Fundação CASA (“A equipe técnica entendeu que a melhor medida a ser aplicada ao adolescente é a medida socioeducativa de internação, cumulada com tratamento para drogadição"), o enunciador delibera o destino da figura do adolescente com a aplicação da medida pleiteada pela figura do Ministério Público (“...internação por prazo indeterminado”) e também aplica a medida protetiva requerida pelas figuras da Fundação CASA e da Defensoria Pública (“...inclusão em programa oficial ou comunitário de auxílio, orientação e tratamento a alcoólatras e toxicômanos"). 
Nesse nível discursivo, mas sob o enfoque do componente semântico, o percurso figurativo dos textos reveste os temas da justiça, da família, da privação da liberdade e da atenção em saúde, que subjazem ao enredo do julgamento, da deliberação sobre a manutenção da custódia da figura do adolescente, da falta de "respaldo familiar" e seu encaminhamento para tratamento em saúde mental.

Seguindo para o nível narrativo de análise, sob o ponto de vista semântico a narrativa lida com a passagem de um estado de internação provisória do adolescente para um estado definitivo de internação, na medida em que a detenção do adolescente, que se verificava provisória num primeiro momento, torna-se definitiva pela decisão judicial. Ainda no patamar narrativo, mas do ponto de vista sintáxico, há na narrativa o enunciado da passagem de um estado de conjunção do adolescente com a expectativa de liberdade para um estado de disjunção com ela.

No nível fundamental da narrativa, a categoria semântica compreende a oposição: atividade versus passividade. Isso porque os temas da justiça, da liberdade e da atenção em saúde estabelecem polaridades ativas e passivas. Com efeito, a figura do adolescente concentrou-se no polo da passividade, pois sua autonomia, independência e autodeterminação são submetidas ao controle das figuras de autoridade, que ocupam o polo da atividade.

A categoria semântica atividade é qualificada nos discursos de forma disfórica (negativa), enquanto que a passividade é tida como eufórica (positiva), dada a convergência dos discursos em prol do controle tutelar da figura do adolescente.

Esta amostra continha documentos referentes à Fundação CASA, ao Ministério Público e à Defensoria Pública. A seguir, esses textos são reproduzidos e submetidos a analise em nível discursivo.

1. Fundação CASA:

Instrumental de coleta de dados do adolescente:

Situação familiar: sem residência fixa (morava em Carapicuíba/SP); pai: não consta informação; mãe viva, empregada doméstica.

Situação escolar: interrompido na $4^{\mathrm{a}}$ série do ensino fundamento; 
Situação de saúde: pino no braço direito; usuário de drogas desde os 7 anos: crack, maconha, solvente;

Situação de trabalho: não trabalha.

Vivência institucional: Semiliberdade, Liberdade Assistida.

Impressões Técnicas: Adolescente já identificado anteriormente. Procedeu entrada através do tal D.P. por envolvimento em ato infracional equiparado a tráfico de entorpecentes. Possui mandado de busca e apreensão por descumprimento de medida socioeducativa de Semiliberdade. Em entrevista relatou que sua família é composta pela genitora, padrasto e 9 irmãos. A família reside em área pública com mínimo de infraestrutura básica em 3 cômodos. $\mathrm{O}$ sustento familiar advém da genitora que trabalha. Adolescente relatou que faz uso de substâncias tóxicas maconha/tiner e crack desde os 7 anos de idade. Já passou por acompanhamento pelo CAPS. Encontra-se fora do convívio familiar em situação de vulnerabilidade na região da Luz.

Relatório Técnico Inicial

Área Psicológica

Encaminhamos para conhecimento de Vossa Excelência o presente relatório, elaborado a partir da reunião de elementos obtidos por intermédio dos procedimentos:

- Entrevistas com o adolescente;

- Consulta à pasta técnica;

- Contato telefônico com a genitora, Sra. Tal;

- Contato telefônico com o funcionário Fulano, do Projeto tal;

- Observação do jovem na rotina institucional, concomitante com a equipe multidisciplinar.

$\mathrm{O}$ adolescente deu entrada neste Centro na data tal, e a partir desta data foi devidamente orientado sobre as regras e normas de convivência, além de receber esclarecimentos sobre o cumprimento da medida de internação provisória que lhe foi determinada.

Em atendimento ao adolescente, ficamos cientes que ele vem frequentando as ruas desde os 07 anos. Verbaliza que permanecia nas ruas diante dos maus tratos sofridos pelo genitor. Informou-nos que este fazia uso de substância etílica e se descontrolava, agredindo-o. Percebemos que o adolescente foi vítima de abandono, pois aos 07 anos, a criança necessita ser cuidada em todos os aspectos.

$O$ adolescente conheceu a cracolândia há mais ou menos 06 anos, dando início ao uso de cola, em grande quantidade passando para o tiner e culminando com o crack. Neste período além de consumir substâncias entorpecentes em grande 
quantidade, o adolescente deu início aos pequenos furtos e tráfico.

Vem sendo assistido na cracolândia pelo Eduardo Sr. Tal, o qual realizou contato e se colocou à disposição para visitas e sanar dúvidas quanto ao caso de o adolescente, assim como nos ofereceu o endereço eletrônico de uma clínica, visando a possível internação do mesmo.

Lendo e estudante (a pasta técnica) o caso deste adolescente, percebemos que já foram oferecidas ao mesmo outras medidas socioeducativas como: abrigamento; Liberdade Assistida, assim como Semiliberdade, porém, sem sucesso. Que independente da medida $o$ adolescente retorna imediatamente para as ruas.

Conseguimos realizar um único contato via fone com sua genitora e esta nos revela que se encontra trabalhando, não dispõe de horário para realizar visitas ao filho. Questionada quanto ao seu envolvimento com as drogas e possível tratamento em clínica, esta nos revela que é difícil, pois assim que seu filho é orientado para aceitação da mesma, concorda, mas desaparece. Quando todos já desistiram de ajudá-lo ele reaparece, ora cumprindo medida de privação, ora totalmente envolvido com as drogas.

Com relação à sua audiência, a genitora declara não saber o horário, quando fomos retornar com a resposta, a ligação havia "caído" e não conseguimos novo contato.

Enquanto interno, observamos mudanças em seu comportamento. Ao dar entrada, apresentava-se sonolento para os atendimentos, logo depois já respondia ao questionado de maneira mais clara e objetiva. Chegou a traçar plano, visando o abandono das drogas e possível tratamento para crescimento, tendo em vista o adolescente ser de compleição física bem abaixo da estatura média para sua idade. Sabemos que o seu desejo é verdadeiro, mas ao ser liberado perde o controle, voltando para o consumo de drogas.

Avaliamos que para obtermos sucesso em seu tratamento, o mesmo poderia permanecer em regime de internação e ser encaminhado para frequentar o CAPS mais próximo de sua unidade de internação.

\section{Área Social}

$O$ adolescente antes dessa apreensão relata que estava morando em um galpão abandonado na região da Luz, conhecida como cracolândia, onde crianças, jovens e adultos invadiram para pernoitarem e utilizarem para outros fins, como consumirem drogas ilícitas, principalmente, o crack.

O adolescente em tela desde 2009 vem tendo envolvimento com atos infracionais, precisamente pequenos furtos e tráfico de 
entorpecentes, ficando nos últimos meses pouco tempo em liberdade, entretanto, vemos um adolescente em situação biopsicossocial altamente vulnerável, não se desenvolvido como deveria nas esferas mencionadas, provavelmente pelo efeito do uso das drogas, tendo estrutura física inferior à idade que possui, sonolento nos atendimentos e de atitudes infantilizadas.

Fazendo um breve histórico da vida do adolescente, os genitores se separaram quando ele tinha tenra idade, aonde chegou a morar com o pai até os 07 anos de idade, mas por sofrer agressões físicas deste (quando ficava alcoolizado), acabou indo residir com a genitora em Carapicuíba (antes morava com o pai em São Bernardo do Campo). No convívio com a mãe foi onde começou a ir para as ruas, iniciando o uso de drogas com 07 anos de idade, vindo posteriormente para o centro desta capital.

A genitora do adolescente teve 10 filhos, frutos de diferentes relacionamentos, onde quatro destes já são casados e de vida independente (aqueles que estão entre a faixa estaria dos 19 aos 30 anos) enquanto os outros 06 ainda residem com a mãe (os de faixa etária entre 03 e 17 anos). Os relatos do adolescente indicam que a genitora não consegue dar a devida atenção para todos os filhos, até mesmo pela quantidade de descendentes aliada ao fato de ter que trabalhar para sustentá-los, ficando assim os irmãos se ajudando mutuamente.

As figuras masculinas que o adolescente em tela teve durante sua infância e adolescência não lhe trazem boas recordações, levando em consideração as agressões do genitor e os maus tratos dos padrastos que possuiu, o que nos leva a sugerir que, além da liberdade exacerbada, o ambiente familiar também contribuiu para que $o$ adolescente começasse a permanecer em vias públicas, como maneira de "fugir" da realidade vivida.

Tivemos grande dificuldade em estabelecer contato com a genitora, e mesmo após obtermos êxito, a mesma não se apresentou disposta ou interessada no caso, verbalizando empecilhos para a realização da visita domiciliar ou entrevista psicossocial, onde não podemos mensurar se tal atitude fora impulsionada por uma negligência ou por estar desiludida com a possibilidade de mudança do filho.

A mãe relatou que trabalha como auxiliar de limpeza, inclusive aos finais de semana. Quanto ao adolescente, resumidamente verbaliza que o filho nunca se empenhou em permanecer em tratamento para drogadição, fugindo do lar assim que obtinha a liberdade ao sair da Fundação Casa. Ademais, a genitora acredita que a única maneira do adolescente deixar o consumo de crack é sendo privado de liberdade e inserido em tratamento para drogadição compulsoriamente.

Obtivemos contato com o funcionário do Projeto tal, que realizam abordagem e acompanhamento de crianças e adolescentes em situação de rua, e este também compartilha da 
mesma opinião da mãe do adolescente, levando em consideração o grau de dependência química do adolescente. Como exemplo disso, citamos o fato do jovem afirmar que chegava a usar 20 pedras de crack por dia.

Contudo, acreditamos que $o$ adolescente não tem estrutura para conseguir cumprir medida socioeducativa em meio aberto ou em semiliberdade, tendo em vista sempre retornar as vias públicas e, simultaneamente, o consumo de crack. Visando a própria integridade biopsicossocial do jovem, e levando em consideração as medidas anteriores não terem surtido o efeito desejado, este técnico entende que o adolescente em questão necessita ser inserido em tratamento para drogadição de forma que esteja impedido de retornar as ruas neste momento de sua vida, até mesmo para que assim, paulatinamente, possam ser resgatados os vínculos necessários para sua reinserção familiar, que atualmente estão rompidos.

\section{Área Pedagógica}

Ao chegar nesta unidade de internação provisória, o jovem foi inserido no Projeto Educação e Cidadania (PEC), conforme Resolução SE 109/03 de 13/10/2003.

Ele foi entrevistado pela Agente Educacional Tal, profissional que trabalha na mesma unidade como seu Agente de Referência e que também propôs ao mesmo a Avaliação Diagnóstica fornecida pela Gerência Escolar da Fundação CASA. $O$ adolescente encontra-se na $4^{\mathrm{a}}$ série do ensino fundamental com 15 anos de idade, relatou o jovem que reprovou por duas vezes a série atual, desde 2007 encontra-se fora do ambiente escolar, com dados nas avaliações diagnósticas que foram aplicadas ao jovem, percebe-se que o mesmo tem dificuldades em leitura e escrita, quanto ao raciocínio tem reais dificuldades nas mais simples operações básicas, o mesmo necessita ser inserido com urgência no ambiente escolar acompanhado de recuperação paralela, neste Centro atualmente o jovem está frequentando o módulo "Trabalho", concluiu o módulo "Educação" fazendo com que se sensibilize o quanto a escola é importante para seu desenvolvimento.

$\mathrm{Na}$ área cultural o jovem está frequentando a oficina de Artes Plásticas ministrada por arte-educadores do Cenpec onde tem participação satisfatória.

Quanto à sua religiosidade, sempre frequenta os cultos evangélicos da igreja evangélica, participa com entusiasmo dos mesmos e relata ter bastante fé.

Em suma, o aluno em entrevista pedagógica recebeu críticas e sugestões acerca de sua trajetória socioeducativa como ponto de reflexão ao diálogo e a discussão de seu caso para incentivo (motivação) aos estudos, momento imprescindível na progressão 
pessoal, educativa, profissional e humano, porém o jovem não tem criticidade.

Área de Segurança

Desde sua entrada neste Centro, o adolescente referido vem demonstrando um bom relacionamento com os demais adolescentes, funcionários, bem como visitantes.

$\mathrm{O}$ adolescente mantém o asseio pessoal de forma correta e satisfatória, não apresenta alteração de comportamento, vem se alimentando diariamente, não possui conduta inadequada no dormitório, se comunica de forma correta, sem gírias e não apresenta características de liderança em relação aos demais adolescentes.

$\mathrm{O}$ adolescente em questão apresenta postura adequada em todos os ambientes deste centro até o presente momento.

Ex.: dormitório, refeitório, procedimento de revista, deslocamento na unidade, bem como, atividades internas e externas.

Considerando o exposto, entendemos que o adolescente demonstra adaptação e cumpre de forma satisfatória a internação provisória.

Área da Saúde

Anamnese:

Adolescente admitido no ambulatório do Casa Tal na data tal. Nega doenças pré-existentes, alergia a medicamentos, contato com portadores de tuberculose, DST's e doenças na família. Informa consumir tiner, maconha e crack, referiu dor em membro superior esquerdo passou em consulta médica com Dr. Tal e conduta medicamentosa.

Metas/ Intervenções propostas

Diante do exposto, percebemos se tratar de jovem que não apresenta estrutura biopsicossocial suficiente neste momento de sua vida para ficar longe do consumo de substâncias psicoativas e da vivência em situação de rua, levando em consideração o grau de dependência química que está, deixando-o assim vulnerável diante das mazelas existentes em nossa sociedade.

Os vínculos familiares se encontram rompidos, onde a genitora não tem sido presente neste processo de ressocialização do filho, o que nos leva a sugerir um trabalho duradouro de resgate dessas relações, para que assim seja interrompida a maneira desregrada que $o$ adolescente vem configurando desde sua infância. Somente assim outros aspectos, como a orientação da genitora 
quanto ao estabelecimento de limites e responsabilidades, para com o filho, poderão ser trabalhados.

Percebemos que o adolescente não tem, neste momento, estrutura para conseguir cumprir com medida socioeducativa em meio aberto ou de semiliberdade, tendo em vista sempre retornar as vias públicas e, simultaneamente, ao consumo de crack.

Visando a própria integridade biopsicossocial do jovem, e levando em consideração as medidas anteriores não terem surtido o efeito desejado, esta equipe técnica entende que o adolescente em questão necessita ser inserido em tratamento para drogadição de forma que esteja impedido de retornar as ruas. Somente sendo trabalhado prioritariamente este aspecto que outras áreas, como o retorno aos estudos de forma eficiente, serão assimilados pelo jovem.

Acreditamos que durante o período de internação, o adolescente poderá frequentar o CAPS AD mais próximo de sua unidade de internação.

Sem mais para o momento, enviamos o presente relatório para apreciação e decisão de Vossa Excelência.

No texto da Fundação CASA intitulado "Instrumental de coleta de dados do adolescente" o relato da figura do adolescente é feito por meio de discurso indireto e com o uso da terceira pessoa do singular (ele), gerando efeitos de realidade pela simulação de um diálogo direto entre entrevistador e entrevistado como num jogo de perguntas e respostas. No momento final, sob a denominação "impressões técnicas", observa-se no enunciado a atribuição da qualidade "situação de vulnerabilidade" à figura do adolescente.

Com relação ao texto denominado "Relatório Técnico Inicial" da Fundação CASA, constata-se que no patamar discursivo o texto é predominantemente temático, apresentando-se dividido em "Área Psicológica”, “Área Social”, “Área Pedagógica”, “Área de Segurança”, “Área de Saúde” e "Metas/Intervenções Propostas”.

O discurso presente na "Área Psicológica” dá voz às figuras do adolescente e de sua mãe mediante discurso indireto, cujo conteúdo é dirigido para fundamentar e balizar as percepções e conclusões do enunciador. Pode-se identificar no texto projeções da enunciação de caráter fatalista com relação ao futuro da figura do adolescente, na medida em que o tempo verbal presente é utilizado no enunciado para marcar uma circunstância de habitualidade ao comportamento considerado inadequado: "Que independente da medida $o$ adolescente retorna imediatamente para as ruas"; "Sabemos 
que o seu desejo é verdadeiro, mas ao ser liberado perde o controle, voltando para o consumo de drogas". Identifica-se no texto o uso da figura de pensamento antífrase (ou ironia) no momento em que o texto trata da figura da mãe do adolescente: "Quando fomos retornar com a resposta, a ligação havia 'caído' e não conseguimos novo contato". Esse procedimento textual, que afirma no enunciado e nega na enunciação produz $\mathrm{m}$ efeito de realidade que busca destacar a ideia de que a ligação telefônica fora desligada intencionalmente pela personagem. O discurso é finalizado com propostas dirigidas ao enunciatário (“... regime de internação e ser encaminhado para frequentar o CAPS mais próximo de sua unidade de internação"), justificadas pela argumentação de cunho fatalista.

Com relação à chamada “Área Social” do texto da Fundação CASA, observa-se que o discurso aborda as relações de causalidade alusivas à condição socioeconômica e de saúde da figura do adolescente, buscando ligar consequências a causas. À "situação biopsicossocial altamente vulnerável”, aponta o consumo de drogas como causa: “... não se desenvolvido como deveria nas esferas mencionadas, provavelmente pelo efeito do uso das drogas". À situação de rua da figura do jovem, o enunciador atribui como causa as relações com a figura da mãe e enuncia esse discurso por meio de vários procedimentos: através do discurso indireto: "relatos do adolescente indicam que a genitora não consegue dar a devida atenção para todos os filhos"; por meio de metáfora: "como maneira de 'fugir' da realidade vivida"; e também como conclusão do enunciador: "o que nos leva a sugerir que ... o ambiente familiar também contribuiu para que $o$ adolescente começasse a permanecer em vias públicas". Identifica-se uma projeção de índole fatalista no enunciado, concretizada pelo emprego do advérbio "sempre": "tendo em vista sempre retornar as vias públicas e, simultaneamente, o consumo de crack".

O discurso contido no segmento textual "Área Pedagógica” apresenta um relato da figura do adolescente sob o ângulo educacional e recorre a terceira pessoa do singular para produzir efeitos de objetividade. O enunciador se utiliza de advérbios de intensidade para ressaltar a participação e o comprometimento da figura do adolescente no campo religioso: "Quanto à sua religiosidade, sempre frequenta os cultos evangélicos da igreja evangélica, participa com entusiasmo dos mesmos e relata ter bastante fé". O enunciador termina o discurso com uma avaliação sobre a figura do adolescente na temática da educação: "o jovem não tem criticidade". 
A parte do texto chamada "Área de Segurança" concretiza os temas da vigilância, da moralidade, da adaptação e do controle por meio da narração descritiva de comportamentos e atitudes da figura do adolescente, considerados satisfatórios na ótica do enunciador: "Considerando o exposto, entendemos que o adolescente demonstra adaptação e cumpre de forma satisfatória a internação provisória”.

$\mathrm{Na}$ sessão do texto denominada "Área da Saúde", o enunciador intitula o discurso como "Anamnese" e apresenta um relato da figura do adolescente feito em discurso indireto que avalia a existência de doenças e o uso de substâncias psicoativas.

O texto da Fundação CASA é finalizado pela sessão "Metas/ Intervenções propostas", na qual o discurso reproduz os conteúdos discursivos da "Área Psicológica", da "Área Social”, da "Área Pedagógica", da "Área de Segurança" e da "Área de Saúde" com o fim de fundamentar uma proposta interdisciplinar de intervenção sobre a figura do adolescente: "Acreditamos que durante o período de internação, o adolescente poderá frequentar o CAPS AD mais próximo de sua unidade de internação".

\section{Termo de Debates:}

MANIFESTAÇÃO DO MINISTÉRIO PÚBLICO: MM. Juiz, o adolescente tal está sendo sindicado tendo em vista os fatos narrados na representação, à qual ora me reporto. Em audiência de apresentação optou por permanecer em silêncio. Em instrução, foram ouvidas duas testemunhas da acusação. É o sucinto relatório. Preliminarmente, requeiro a conversão do julgamento em diligência, para a cobrança do laudo de exame químico toxicológico. Quanto ao mérito, desde logo, opino pela procedência da representação. A materialidade restou demonstrada pelo auto de exibição e apreensão de fls. tais e pelo laudo de constatação de fls. tais. Também restou demonstrada a autoria do ato infracional. Os policiais nesta data ouvidos confirmaram ter abordado o adolescente na Cracolândia, adolescente que tinha em seu poder as drogas descritas na inicial. O adolescente tinha também dinheiro em seu poder e admitiu a prática do tráfico. Nota-se que, embora em Juízo o adolescente tenha ficado em silêncio, admitiu a prática do ato infracional quando de sua oitiva informal. É evidente que as drogas se destinavam a entrega a terceiros, tendo em vista sua elevada quantidade, assim como a confissão extrajudicial. Procedente a representação. Resta Analisar a medida a ser aplicada. O adolescente é reincidente, já tendo recebido orientações que restaram infrutíferas, vez que insiste em infracionar. Estava em descumprimento de semiliberdade, e encontrava-se sob ordem de busca e apreensão. $\mathrm{O}$ adolescente está fora do convívio familiar, em situação de vulnerabilidade. Revela com seu proceder índole infracional latente que precisa ser tratada e revertida em nível institucional para que introjete normas mínimas de convivência em 
sociedade, sem o que não terá condições de integrá-la como indivíduo adaptado e útil. A medida extrema apresenta-se de rigor, nos termos do art. 122, inciso II do ECA. Ante o exposto, ratifico o requerimento apresentado em preliminar, e no mérito, opino seja julgada procedente a representação aplicando-se ao adolescente a medida socioeducativa de internação, prevista no art. 112, inciso VI, ECA. Nada mais.

MANIFESTAÇÃO DA DEFENSORIA: MM. Juiz, o adolescente tal foi representado e está sendo processado por suposto ato infracional equiparado a tráfico (art. 33 da Lei 11343/06). Narra a representação que, no dia tal, por volta das tantas horas, o jovem estaria na Rua Tal trazendo consigo porções de crack para fins de tráfico, além de portar $\mathrm{R} \$ 72,00$ em dinheiro. Ouvido em audiência de apresentação, $o$ adolescente preferiu exercer seu direito de permanecer em silêncio, o que não pode ser valorado em desfavor do menino nem retira da acusação o ônus de comprovar devidamente a acusação. Nesta data, a prova se limita aos depoimentos dos policiais. A ação não merece procedência. Não há comprovação da materialidade ao ato infracional imputado, vez que o laudo definitivo da substância apreendida não foi juntado aos autos. A prova limitada aos depoimentos policiais é frágil. Observa-se que nenhum comprador além dos próprios envolvidos na diligência foi sequer qualificado, até porque eles sabem que se exige sempre muito pouco para atribuição de tráfico a adolescentes. Acrescenta-se que os policiais envolvidos na diligência não prestam depoimentos absolutamente idôneos pois têm interesse no deslinde da causa, até para verem legitimadas suas ações anteriores. Ante o exposto, peço a improcedência da representação. Subsidiariamente, peço pela aplicação de medida diversa da internação. $O$ adolescente vem se envolvendo em atos infracionais desde o mês tal do ano tal, todos por furto, tráfico... Nenhum dos atos infracionais apurados envolveram violência ou grave ameaça, sendo todos usados como meios de aquisição de dinheiro para posterior uso de drogas. De fato, segundo instrumental de coleta de dados, desde os 07 anos de idade o jovem usa crack, maconha, solvente, tanto que, aos 15 anos de idade, sua compleição física é infantil. Na Fundação CASA, o jovem será meramente privado de liberdade, contido, sem que sua verdadeira demanda seja apurada e devidamente trabalhada. O mais provável é que, após alguns meses de internação, às vésperas de sugerir sua progressão para outra medida socioeducativa, a Fundação CASA leve o adolescente para começar o tratamento em CAPS AD. A demanda do adolescente será negligenciada durante vários meses. Preso há quase 40 dias, sequer consta nos autos alguma avaliação psicossocial ou psiquiátrica um pouco mais detalhada do jovem, demonstrando o quanto sua demanda de saúde será negligenciada se permanecer meramente privado de liberdade, sem o encaminhamento para equipamento de saúde adequado. Recorda-se que a Fundação CASA é equipamento de segurança e não de saúde, ali não há médicos e enfermeiros, senão em dias determinados para atendimentos que se façam necessários. A sua internação estaria em desacordo com o previsto no $112, \S 3^{\circ}$, do ECA, segundo o qual os jovens que tenham algum tipo de doença mental "receberão tratamento individual $\mathrm{e}$ especializado, em local adequado às suas condições". A internação não estaria também de acordo com as circunstâncias pessoais do jovem, sendo mais a efetivação da fórmula mais corriqueira e fria de 
aplicação de medidas socioeducativas gradativamente: liberdade assistida/prestação de serviços, semiliberdade e internação, sempre em direção à medida mais grave, esperando-se cegamente algum tipo de "ressocialização". Por fim, sem que haja sequer um exame psicossocial mais detalhado, a internação seria aplicada sem análise de sua necessidade e sem passar pelo crivo da excepcionalidade, sendo ilegal, portanto. Desse modo, superada a improcedência da representação, peço que o adolescente seja encaminhado eventualmente para medida socioeducativa diversa da internação, cumulada com medida protetiva do art. 101, VI, do ECA. Nada mais.

Esse texto, denominado "Termo de Debates", produz efeitos de realidade ao se apresentar como constituído de um diálogo entre duas figuras: o Ministério Público e a Defensoria Pública, que estabelecem uma polêmica ao enunciarem argumentações e conclusões confrontantes. A "Manifestação do Ministério Público" enuncia uma argumentação baseada em figuras probatórias (testemunhas, perícia e confissão) para fundamentar conclusões de cunho subjetivo ("Revela com seu proceder índole infracional latente que precisa ser tratada e revertida em nível institucional para que introjete normas mínimas de convivência em sociedade, sem o que não terá condições de integrá-la como indivíduo adaptado e útil”) que sinalizam uma projeção de ordem fatalista ao enunciado. Já o texto presente na chamada "Manifestação da Defensoria Pública" confronta a argumentação e a conclusão do discurso anterior através da concretização da temática da injustiça, desqualificando as figuras probatórias ("Não há comprovação da materialidade ao ato infracional... A prova limitada aos depoimentos policiais é frágil") e o próprio rito processual, tomado como procedimento automático e padronizado: "A internação não estaria também de acordo com as circunstâncias pessoais do jovem, sendo mais a efetivação da fórmula mais corriqueira e fria de aplicação de medidas socioeducativas ... esperando-se cegamente algum tipo de 'ressocialização"”. 


\section{APÊNDICE E - Quinta amostra}

Esta quinta amostra apresenta os documentos do processo do ano de 2011, que tramitou pela tal Vara Especial da Infância e da Juventude de São Paulo, versando sobre ato infracional, consistente em tráfico de drogas, referido ao adolescente tal, de 16 anos de idade. Esta amostra conta com textos produzidos pelo Juízo de Direito e pelos textos originários do Ministério Público, da Polícia Civil e da Fundação CASA.

1. Textos do Juízo de Direito:

Despacho interlocutório:

Vistos.

1. Estando presentes indícios de autoria e materialidade, recebo a representação.

2. Decreto a INTERNAÇÃO PROVISÓRIA do adolescente tal nos temos do artigo 108, parágrafo único, c.c. o artigo 122, inciso II, ambos do Estatuto da Criança e do Adolescente.

3. Ressalto que a medida é imperiosa, para garantia da segurança social do adolescente, bem como para manutenção da ordem pública e considerando ainda, a repercussão social do ato infracional.

4. Com efeito, trata-se de adolescente com passagens por este Sistema de Justiça, tendo recebido medidas socioeducativas de liberdade assistida cumulada com prestação de serviços à comunidade recentemente, havendo indícios de que encontra-se envolvido com a prática de tráfico de drogas.

5. Designo audiência de apresentação para o dia tal às tantas horas.

6. Notifiquem-se e intimem-se.

7. Atenda-se, no mais, o requerido pelo MP.

8. Nomeio um dos Defensores Públicos atuantes nesta Vara, para defender os interesses do adolescente, ressalvado o direito de, a todo tempo, o jovem constituir outro Defensor de sua preferência (art. 207, parágrafo $1^{\circ}$ do E.C.A.).

9. Int.

Audiência de Apresentação:

DECLARAÇÕES DO ADOLESCENTE: orientado quanto ao direito de permanecer em silencia e que o uso de tal prerrogativa não poderá ser usado em seu desfavor, tem 16 anos. Tem passagem anterior pela qual recebeu medida de prestação de serviço à comunidade. Não faz uso de entorpecentes. Mora com seus pais. Confessa a prática infracional. Estava com os entorpecentes descritos na representação, que lhes foram fornecidos pelos "caras da biqueira". Recebia R\$ 
100,00 (cem reais) por dia. A droga se destinava ao comércio. O local é uma biqueira. Está arrependido e concorda em tratamento para se livrar das drogas. Nada mais.

REPERGUNTAS PELO DR. PROMOTOR: Nada mais.

REPERGUNTAS PELO DR. DEFENSOR: Nada mais.

MANIFESTAÇÃO DA DEFESA: MM. Juiz, protesto pela inocência do adolescente que se demonstrará no decorrer da instrução. A Defesa ainda arrola como suas as testemunhas arroladas na representação. Nada mais.

DELIBERAÇÃO: Designo audiência de instrução, debates e julgamento para o dia tal, às tantas horas, promovendo-se o necessário. Saem os presentes intimados.

Termo de Audiência de Instrução, Debates e Julgamento

ENCERRAMENTO DA INSTRUÇÃO E DEBATES: As partes desistiram da produção de demais provas, o que foi homologado pelo MM. Juiz. Encerrada a instrução, passaram-se aos debates, que foram colhidos em termo apartado.

SENTENÇA: O adolescente sofre este procedimento apuratório acusado da prática de ato infracional equivalente a tráfico, conforme minuciosa descrição da inicial. A representação foi recebida e o adolescente ouvido em audiência de apresentação. Nesta data, foi ouvida uma testemunha da acusação. Ao cabo da instrução, desistiram as partes dos demais meios de prova, tendo o Ministério Público finalizado requerendo a procedência da representação e a aplicação da medida de internação. Já a Defesa, de seu turno, pugnou pela improcedência, por falta de provas. Alternativamente, requereu a aplicação de medida mais branca. DECIDO: A ação socioeducativa é procedente. A materialidade do ato infracional está comprovada com base no laudo fls. tais. Por sua vez autoria é certa. Em audiência de apresentação perante este Juízo o adolescente confessou a prática do ato infracional. A confissão do adolescente foi corroborada na presente audiência de instrução, debates e julgamento em face do depoimento da testemunha tal que afirmou que abordara o adolescente em "um ponto de tráfico" com os entorpecentes descritos na representação. Ressaltou que o adolescente confirmou no local a prática do ato. Diante da confissão do adolescente, bem como das declarações da referida testemunha considerando o local onde o adolescente foi apreendido, a quantidade de entorpecentes e sua forma de acondicionamento entendo que a prova é segura para a procedência da ação socioeducativa. Passa-se ao exame da medida a ser aplicada à espécie. $\mathrm{O}$ adolescente é reincidente, já tendo praticado atos infracionais referidos ao delito de furto e tráfico de entorpecentes, tendo recebido as medidas de liberdade assistida e prestação de serviços à comunidade cumulativamente nas duas oportunidades. De acordo com o relatório técnico juntado aos autos, o adolescente está inserido em família desestruturada, não está estudando, faz uso de entorpecentes, vem praticando atos infracionais há algum tempo, está convivendo com pessoas de má índole, está identificado com o meio infracional. Diante deste contexto entendo que deva ser aplicada ao adolescente a medida socioeducativa de internação cumulada com a medida de tratamento para drogadição. Pelo exposto, JULGO PROCEDENTE A REPRESENTAÇÃO, e com fundamento no art. 
122, II do ECA, confirmo a internação provisória e aplico ao adolescente a medida de INTERNAÇÃO, sem prazo determinado, cumulada com medida protetiva prevista no artigo 101, inciso VI, do ECA, consistente em inclusão em programa oficial ou comunitário de auxílio, orientação e tratamento a alcoólatras e toxicômanos, com reavaliação a cargo do Juízo da Execução. Oficie-se à Fundação CASA para que proceda a transferência do adolescente para unidade adequada, no prazo máximo de 10 dias, sob pena de responsabilidade. Publicada a audiência, dou por intimados os presentes. Registre-se. Após o trânsito em julgado, arquivem-se os presentes autos.

Empreendendo a Análise do Discurso pelo nível discursivo do percurso gerativo de sentido, pode-se observar, sob o ponto de vista sintáxico, que o texto do juiz chamado "Despacho Interlocutório" é formulado em primeira pessoa do singular (subjetividade) e acompanha o requerido pela figura do Ministério Público, com argumentação equivalente, relativa à contenção de uma ameaça de ordem social: "Ressalto que a medida é imperiosa, para garantia da segurança social do adolescente, bem como para manutenção da ordem pública e considerando ainda, a repercussão social do ato infracional".

No texto intitulado "Audiência de Apresentação", o enunciador apresenta o relato da figura do adolescente feito em terceira pessoa do singular, em discurso indireto e com a indicação da participação das figuras do Promotor e do Defensor na qualidade de questionadores. Esses recursos estilísticos ensejam o sentido de objetividade ao discurso. O relato da figura do adolescente revela uma incoerência com relação ao consumo de drogas: a princípio, há a negativa de seu uso ("Não faz uso de entorpecentes") e, ao final, há a concordância na adesão de "tratamento para se livrar das drogas". O texto também apresenta o discurso da Defesa, no qual o enunciador confronta a tese discursiva defendida pelo Promotor, propondo-se a argumentar no momento oportuno.

Já no texto chamado "Termo de Audiência de Instrução, Debates e Julgamento" o enunciador conclui pelo acolhimento do requerido pela figura do Ministério Público (“... tendo o Ministério Público finalizado requerendo a procedência da representação e a aplicação da medida de internação"), em oposição ao formulado pela Defesa ("Já a Defesa, de seu turno, pugnou pela improcedência, por falta de provas. Alternativamente, requereu a aplicação de medida mais branca"). O conteúdo conclusivo do discurso também converge para o entendimento apresentado pela Fundação CASA ("De acordo 
com o relatório técnico juntado aos autos, o adolescente está inserido em família desestruturada, não está estudando, faz uso de entorpecentes, vem praticando atos infracionais há algum tempo, está convivendo com pessoas de má índole, está identificado com o meio infracional“). A argumentação enfatiza a confissão e a reincidência da figura do adolescente, ao qual são aplicadas as medidas de internação e de proteção: “aplico ao adolescente a medida de internação, sem prazo determinado, cumulada com medida protetiva prevista no artigo 101, inciso VI, do ECA, consistente em inclusão em programa oficial ou comunitário de auxílio, orientação e tratamento a alcoólatras e toxicômanos".

Nesse mesmo nível discursivo, o componente semântico se apresenta concretizado pelos temas da justiça, da família, da privação da liberdade e da atenção à saúde, subjacentes ao percurso figurativo do julgamento, da situação familiar "desestruturada" da figura do adolescente e das manifestações sobre a manutenção da apreensão e da adesão ao tratamento em saúde por parte da figura do jovem.

No nível narrativo, o componente semântico trata da passagem de um estado de indefinição (julgamento) da figura do adolescente para um estado de definição (sentença). Sob o ponto de vista sintático, há na narrativa o enunciado da passagem de um estado de conjunção da figura do adolescente com a expectativa para um estado de disjunção com ela e, simultaneamente, a passagem de um estado de disjunção com o atendimento em saúde para um estado de conjunção com ele.

Em nível fundamental ou profundo, a estrutura semântica da narrativa é composta pelas polaridades: atividade versus passividade. Isso em razão da relação entre a figura do adolescente e das figuras de autoridade se constituir nas vertentes passiva e ativa. Com efeito, a qualidade da estrutura semântica atividade é tratada nos discursos de forma negativa ou disfórica, enquanto que a passividade é tomada como positiva ou eufórica.

\section{Ministério Público:}

Consta do incluso B.O. que, no dia tal, por volta das tantas horas, na rua $\mathrm{tal}$, nesta cidade e comarca, o adolescente tal trazia consigo droga, sem autorização e em desacordo com determinação legal ou regulamentar.

Apurou-se que o adolescente encontrava-se no local dos fatos quando foi abordado por policiais militares. Efetuada revista pessoal no 
adolescente, foram localizadas em seu poder tantas porções de cocaína, tantas porções de maconha e tantas porções de crack, conforme laudo de constatação tal.

As circunstâncias da apreensão, a quantidade, a diversidade e a forma de acondicionamento das substâncias evidenciam que as mesmas se destinavam ao tráfico.

Trata-se desta feita, em tese, da prática do ato infracional previsto no art. 33, da Lei $\mathrm{n}^{\mathrm{o}} 11.343 / 2006$.

Devidamente cientificado da imputação que lhe é feita e que ora consta da representação, o adolescente foi ouvido informalmente, nos termos do artigo 179, do ECA. Na presença de sua genitora, admitiu a prática do ato infracional, esclarecendo que está atuando na mercancia ilícita faz três meses, ganhando $R \$ 100,00$ por dia.

Assim, com fundamento nos artigos 180, inciso III e 201, inciso II, ambos da Lei $\mathrm{n}^{\circ}$ 8.069/90, REPRESENTO a V. Exa. o adolescente supramencionado, pretendendo a aplicação da medida socioeducativa prevista no artigo 112, e requeiro a instauração do devido procedimento legal, previsto no artigo 184 e seguintes, também do mesmo Estatuto.

Destarte, é preciso requerer a decretação da INTERNAÇÃO PROVISÓRIA do adolescente. Trata-se de fato grave e adolescente reincidente, circunstâncias que denotam a impossibilidade, por ora, do jovem permanecer no convívio social.

Requeiro oficie-se ao D.P. de origem para que encaminhe o laudo definitivo das substâncias apreendidas.

A análise do texto oriundo do Ministério Público, do ponto de vista discursivo sintático, demonstra que, num primeiro momento, o enunciador, dando objetividade ao discurso pelo uso da terceira pessoa do singular, pressupõe como verdadeiros os fatos narrados pela figura da polícia (“Consta do incluso B.O. que...”) e os reproduz no discurso para fins argumentativos. A argumentação também é composta do relato da figura do adolescente, particularmente sobre a admissão de culpa por parte deste ("Na presença de sua genitora, admitiu a prática do ato infracional, esclarecendo que está atuando na mercancia ilícita faz três meses, ganhando R\$100,00 por dia"). Num segundo momento, o enunciador flexiona a pessoa verbal para a primeira do singular (subjetividade) e apresenta seu requerimento ao enunciatário (“...é preciso requerer a decretação da internação provisória do adolescente"), cuja possível negativa é associada a uma ameaça de ordem social ("Trata-se de fato grave e adolescente reincidente, circunstâncias que denotam a impossibilidade, por ora, do jovem permanecer no convívio social"). 


\section{Polícia Civil}

Comparece a esta Unidade o policial militar noticiando que em patrulhamento pelo local dos fatos com o soldado tal avistou um jovem assumir um comportamento suspeito ao notar a aproximação de sua viatura. Em continuidade foi mantido o acompanhamento ao suspeito pelo espelho retrovisor, ocasião em que viu o jovem esconder algo sob papelões próximos aos pés na calçada onde estava. Em seguida, retornou ao local para abordar o suspeito, encontrando sob sua posse certa quantia em dinheiro "trocado", assim como sob os citados papelões foi localizada uma carteira contendo diversas substâncias aparentemente entorpecentes (tantos pinos de cocaína, tantas pedras de crack e tantos papelotes de maconha).

Indagado a respeito, o adolescente infrator não soube explicar a procedência do dinheiro e do entorpecente.

Diante dos fatos, o adolescente infrator foi detido e conduzido a esta distrital, juntamente com as substâncias e valores com ele encontrados.

Ciente dos fatos, esta Autoridade deliberou pelo presente registro, bem como pela formal apreensão da substância apresentada, a qual foi enviada ao IC para exame de constatação, gerando o Laudo de Constatação $\mathrm{n}^{\mathrm{o}}$ tal, anexo aos autos, cujo resultou positivo para o material examinado.

Em tempo compareceu a genitora do adolescente infrator, narrando que desconhecia a procedência do dinheiro que seu filho possuía no momento da abordagem policial, bem como afirmou ter mandado ele parar de trabalhar na "biqueira", que não mais o queria envolvido no "tráfico", dizendo ainda que pela sua vontade seu filho deveria ser enviado à "FEBEM".

Por meio de pesquisa ao sistema RDO, apurou-se que o adolescente infrator recentemente foi encaminhado por duas vezes a Fundação CASA.

Conforme o dispositivo legal, o adolescente infrator foi entregue a genitora, mediante a assinatura do Termo de Responsabilidade - ECA. Nada mais.

No texto produzido pela Polícia Civil, podemos observar a construção de uma narrativa linear, elaborada na terceira pessoa do singular e mediante discurso indireto. Por meio desses procedimentos, o discurso produz efeitos do real. Inicialmente, a narrativa trata da apreensão em flagrante da figura de um adolescente acusado da prática de tráfico de drogas. A responsabilidade pela versão da narrativa é atribuída à figura do policial militar condutor ("Comparece a esta Unidade o policial militar noticiando que...”). O discurso também contém o relato da figura da mãe do adolescente, no qual é enfatizada a sua posição em relação ao destino que se deve dar ao filho: "afirmou ter 
mandado ele parar de trabalhar na 'biqueira' que não mais o queria envolvido no 'tráfico', dizendo ainda que pela sua vontade seu filho deveria ser enviado à 'FEBEM'". O discurso é finalizado com a narrativa da liberação da figura do adolescente.

\section{Fundação CASA:}

Relatório Técnico Inicial

O relatório foi elaborado através de dados fornecidos pelo adolescente, consulta a pasta técnica, entrevista com a genitora e discussão do caso com a equipe multidisciplinar.

O jovem registrou entrada na data tal em virtude da imputação de ter praticado o ato infracional tipificado como Tráfico de entorpecentes.

Trata-se de um adolescente que conta com passagem anterior pela Fundação, na data $t a l$, visto a prática de tráfico de entorpecentes.

$\mathrm{Na}$ época da representação judicial o jovem foi beneficiado com as medidas socioeducativas de Liberdade Assistida e Prestação de Serviço à comunidade.

Por se tratar de Unidade de Internação Provisória caracterizada por Unidade Diagnóstica, no período em que o adolescente aqui permanece está sendo acompanhado pela equipe multiprofissional, a qual elaborou o Diagnóstico Polidimensional que servirá de subsídio para a construção do PIA - Plano Individual de Atendimento.

\section{Área social}

Segundo o adolescente compareceu em três atendimentos técnicos quanto à medida de Liberdade Assistida, depois não quis retornar. E quanto à medida de Prestação de Serviço à Comunidade ainda não tinha iniciado.

Abordado referente à atual imputação delitiva, o adolescente declarou que estava com uma dívida no valor de $\mathrm{R} \$ 50,00$, no dia da ocorrência foi procurado pelo colega Fulano e pressionado a pagar o referido valor, desta forma, decidiu traficar e assim quitar a dívida.

$O$ Adolescente revelou que começou a traficar com dez anos de idade, devido o ganho fácil. Na faixa etária dos catorze anos a genitora teve conhecimento, então, a referida buscou persuadi-lo a cessar tal conduta.

Expôs que na referida época praticou alguns roubos como saída de banco e subtrair aparelho celular. Acrescentou-nos que sempre agiu sozinho e esta conduta perdurou por um ano, retornando ao tráfico de entorpecentes.

Perguntado quanto ao uso de substâncias entorpecentes, o jovem referiu que desde os doze anos de idade faz uso de maconha, o consumo era diário e a aquisição se dava por conta própria. 
Acerca de círculo de amizades, o adolescente verbalizou que se trata de um grupo mesclado, as nefastas são usuários de drogas, traficantes e alguns que praticam roubos.

Segundo o adolescente interrompeu os estudos na $6^{\mathrm{a}}$ série do Ensino Fundamental, devido seu envolvimento com o tráfico de entorpecentes.

O jovem citou que já se evadiu da escola por duas vezes, devido desinteresse.

Em relação à atividade laborativa, o adolescente declarou que não estava trabalhando. Anteriormente já desempenhou o ofício de ajudante geral de mecânico em meados do ano tal, permanecendo no emprego por dois meses, ficou desmotivado.

No que concerne à estrutura familiar, o adolescente respondeu que os genitores conviveram dezoito anos.

A ruptura do relacionamento ocorreu há alguns meses por motivo de discussão porque o pai pernoitou fora do lar.

Após a separação ele ficou sob os cuidados da mãe.

Atualmente o pai reside no município tal, é caseiro de uma chácara e tem uma microempresa de solado de sapatos. Afirmou-nos que tem contato frequente com o genitor, este não fornece pensão alimentícia, mas auxilia financeiramente quando lhe solicitado.

$O$ adolescente salientou que tem três irmãos, sendo Fulana, Sicrana e Beltrana, concebidas de relacionamentos distintos por parte da mãe, bem como tem um irmão, o tal, concebido de uma união do pai.

Até a apreensão residia com a mãe e com a irmã Beltrana.

A família reside em moradia própria composta por três cômodos de alvenaria provida de infraestrutura básica.

A renda advém do ofício da mãe, que trabalha como empregada doméstica.

O relacionamento familiar foi apontado pelo jovem como regular. Frisou-nos que não tem diálogo com os genitores, sendo que discute mais com a mãe, não acata suas orientações, não aceita normas, não gosta de se sentir preso.

$O$ adolescente revelou que o genitor fazia uso de bebida etílica e era agressivo com ele quando realizava algo de errado. Verbalizou que não tem respeito e sim medo do pai.

$\mathrm{O}$ adolescente acrescentou que tinha o hábito de pernoitar fora do lar, bem como retornar de madrugada.

Em entrevista a genitora, Sra. Tal, (43 anos), relatou que teve relacionamentos distintos, dos quais foram concebidas as filhas: Fulana (27 anos - casada há sete anos - auxiliar de limpeza), Sicrana (25 anos - casa há três anos - deficiente auditiva - estuda em escola especial) e Beltrana (23 anos - solteira - interrompeu os estudos na $7^{\text {a }}$ série

Ensino Fundamental - não trabalha).

Posteriormente conviveu maritalmente dezoito anos com o Sr. Tal (58 anos), desta união foi concebido o adolescente. 
Expôs que se separaram há oito meses, mas estão conversando quanto à possibilidade de reconciliação.

A genitora pontuou que o Sr. Tal não se afastou do filho, inclusive neste período da separação percebeu que eles ficaram mais próximos.

Segundo a Sra. Tal o ex-marido há dez anos não faz mais uso de bebida etílica. Acrescentou-nos que ele era agressivo quando desejava por limites ao adolescente.

A Sra. Tal mencionou que trabalha como empregada doméstica, o salário corresponde ao valor de R $\$ 700,00$ por mês. Quanto ao Sr. Tal, referiu que ele montou uma microempresa de solado de sapatos, mas não está tendo muito lucro, reside numa chácara na cidade tal, sendo caseiro.

Em relação ao adolescente, a genitora pontuou que este ano ele iria retomar os estudos, pois já tinha realizado a matrícula.

Segundo a Sra. Tal, o filho compareceu em três atendimentos técnicos no Posto de Liberdade Assistida, depois passou a apresentar resistência, devido influência das amizades. Acrescentou-nos que o jovem não deu início ao cumprimento da medida de Prestação de Serviços à Comunidade.

Quanto às amizades do adolescente, a genitora verbalizou que as nefastas são usuários de drogas.

Inquirida quanto ao envolvimento do adolescente, como usuário de substâncias entorpecentes, a mãe expressou que teve conhecimento em meados do ano tal que o epigrafado fazia uso frequente de maconha.

Acerca do envolvimento do adolescente com o tráfico de entorpecentes, a genitora negou o relato do filho, o qual disse que ela teve conhecimento quando ele contava com catorze anos de idade.

A Sra. Tal mencionou que devido sua jornada de trabalho não tem condições de acompanhar a rotina do jovem, mas nunca ouviu comentários negativos da vizinhança referente ao mesmo.

Cabe-nos pontuar que no decorrer do atendimento o jovem se portou de modo receptivo, todavia, apresentou um relato contraditório, buscou minimizar suas condutas pregressas, apresentou um discurso pré-elaborado quando estimulado a refletir referente mudanças de comportamento.

Transpareceu-nos que o adolescente tem envolvimento acentuado com o meio delitivo, que não se desvinculou do tráfico de entorpecentes e continuou com as mesmas amizades.

Embasada no relato do adolescente e da genitora, esta apresentou uma postura protetora, não conseguindo admitir o envolvimento do filho com o meio delitivo, bem como que ela e o pai do jovem não conseguem impor limites ao mesmo.

\section{Área Psicológica}

O presente estudo psicológico foi realizado através de dados fornecidos em consulta a pasta social, atendimento técnico individualizado ao adolescente. 
Trata-se de um jovem de 16 anos de idade e 09 meses, proveniente de um lar em que foi criado pelas figuras parentais, mas, recentemente os genitores separaram, o qual tem para si que estão tentando reconciliar.

Durante seu desenvolvimento, provavelmente a atividade laborativa das figuras parentais ocasionou a carência de um monitoramento efetivo, além de problemas de relacionamento com a figura paterna devido realizar uso de etílicos, suscitou precocemente o acesso às amizades negativas, além de observarmos uma relação distanciada com os responsáveis.

Desde seus dez anos de idade acabou afeito à conduta do tráfico, o qual gradativamente assume uma ascensão e vislumbrou sua independência pela aquisição financeira.

Embora reconheça os prejuízos para a sociedade, observamos não ser freio para a conduta negativa, assim como manifestou discurso préelaborado quando estimulado a nova possibilidade de vida.

Observa-se que não valorizou a medida anteriormente aplicada, haja vista continuar com as mesmas escolhas, quanto às amizades, conduta de vida e uso contínuo de substâncias psicoativas de cannabis sativa que ocorre de forma frequente, desde seus doze anos de idade.

Durante a entrevista, inicialmente necessitou de estímulos quanto suas reais escolhas e denotou certa resistência e, conforme seu discurso observamos um adolescente com envolvimento efetivo no tráfico de entorpecente, bem como seu núcleo familiar não consegue coibir e direcioná-lo a uma conduta assertiva de vida.

Perante o exposto, faz necessário o jovem ser estimulado por uma equipe multidisciplinar a desenvolver suas potencialidades e, através dos atendimentos psicossociais, estimulado a valorizar novas possibilidades de vida.

\section{Área Pedagógica}

$\mathrm{O}$ adolescente informou em entrevista inicial pedagógica que estava matriculado no $2^{\circ}$ termo do ciclo II dos EJA - Educação de Jovens e Adultos d EMEF Tal, informações confirmadas pela Prodesp.

Com o objetivo de obter maiores dados de duas habilidades de leitura, escrita e matemática básica, para colocarmos em prática eventual intervenção pedagógica, caso seja necessária, o jovem realizou a Avaliação Diagnóstica, baseado em metodologia utilizada na elaboração do INAF - Índice Nacional de Analfabetismo Funcional. Constatou que o jovem é analfabeto e será inserido em uma sala para alfabetização.

Nas atividades esportivas tem uma boa interação com os colegas da sua sala quando esta praticando esportes como pebolim, futebol de salão, condicionamento físico e ping-pong. Nesses esportes ele apresenta bom comportamento e compreensão em relação às regras.

Desde a sua entrada na Unidade, o adolescente vem sendo avaliado quanto às suas habilidades e competências pedagógicas. Até o momento, mostra-se acessível às orientações dos educadores que o acompanham e apresenta disponibilidade para praticar as normas de convivência. 
O jovem foi informado sobre o trabalho voluntário desenvolvido em parceira com o PAR - Programa de Assistência Religiosa, ao qual poderá participar se assim desejar.

Em relação às atividades de Arte e Cultura, o jovem foi inserido nas oficinas de "Vídeo e Arte", na qual aprende conceitos básicos, técnicos e práticos sobre a produção de mensagens e poesia, cujo objetivo é ampliar o universo cultural do adolescente com noções de como elaborar versos e poemas trabalhando a objetividade e sua realidade pessoal. Essas atividades são realizáveis em parceria com o CENPEC - Centro de Estudos e Pesquisas em Educação, Cultura e Ação Comunitária.

Portanto, temos a informar que desde a sua entrada nessa Unidade, o adolescente vem realizando os trabalhos propostos em sala de aula e pratica as normas de convivência.

\section{Área Segurança}

Até o momento o jovem tem promovido comportamento disciplinar de acordo com as normas de convivência desta Unidade e se relaciona bem como os demais jovens e com os funcionários.

\section{Sugestões de Acompanhamento}

Embora possua as figuras parentais, sugerimos a inserção destes em grupo de orientação e apoio às famílias, conforme discurso do adolescente mantém uma relação distanciada, com pouco diálogo, o qual poderá efetivamente melhorar nas relações e na ascendência sobre o filho.

Perante o exposto, faz necessária a intervenção sistemática em acompanhamento multidisciplinar a fim de estimular a novas possibilidades de vida como valorização e retorno ao núcleo escolar, inserção em cursos profissionalizantes, além de repensar efetivamente quanto ao caminho que buscou trilhar e nos reais prejuízos de vida.

Sendo o que tínhamos a informar, encaminhamos o presente para apreciação e decisão judicial.

O texto proveniente da Fundação CASA: "Relatório Técnico Inicial" é predominantemente temático, apresentando-se dividido em "Área Social”, "Área Psicológica”, “Área Pedagógica”, “Área de Segurança” e "Sugestões de Acompanhamento".

O discurso referente à "Área Social” apresenta o relato da figura do adolescente feito em terceira pessoa do singular e em discurso indireto (efeitos de objetividade), no qual é retratada a história do envolvimento da figura do adolescente com o tráfico de drogas, bem como a história de suas relações familiares e de seu círculo de amizades. Antes da finalização, o discurso é flexionado em primeira pessoa do plural (efeito de 
atração do narratário), cujo conteúdo é conclusivo no sentido de advertir o enunciatário sobre a postura resistente da figura do adolescente. O texto é finalizado em terceira pessoa do singular (objetividade) e atribui à figura dos pais do adolescente uma parcela de responsabilidade pela atual condição do filho.

O texto da "Área Psicológica" desenvolve a tese de que a causa da atual situação da figura do adolescente está ligada à carência afetiva, atribuída à figura dos pais do adolescente, o qual, diante dessa carência, estabeleceu vínculos de amizades "negativas". O discurso também foca na desvalorização dada pela figura do adolescente à medida socioeducativa que lhe fora anteriormente aplicada, concluindo que a figura do jovem deva ser assistida por "equipe multidisciplinar" em função da incapacidade de sua família "coibir e direcioná-lo a uma conduta assertiva de vida". O discurso é elabora com efeito de realidade pelo uso da terceira pessoa do singular e do discurso indireto.

$\mathrm{Na}$ "Área Pedagógica", o texto traz o relato da figura do adolescente sob o aspecto educacional e utiliza o discurso indireto e a terceira pessoa do singular para produzir efeitos de objetividade. $\mathrm{O}$ enunciador enfatiza a participação e o cumprimento das "normas de convivência" por parte da figura do adolescente.

O seguimento "Área de Segurança" do texto apresenta um discurso relativo à temática da disciplina e do controle, destacando a adaptação da figura do adolescente às "normas de convivência" institucional.

O item final do texto: "Sugestões de Acompanhamento", aponta intervenções que poderiam ser determinadas pelo enunciatário, quais sejam, a inclusão da figura dos pais do adolescente em grupos de apoio e orientação e a assistência à figura do adolescente em equipe multiprofissional. 


\section{APÊNDICE F - Petição judicial}

\section{EXCELENTÍSSIMO SENHOR DOUTOR EGBERTO DE ALMEIDA PENIDO, JUIZ DE DIREITO DA VARA ESPECIAL DA INFÂNCIA E DA JUVENTUDE DO ESTADO DE SÃO PAULO.}

RICARDO HENRIQUE SOARES, brasileiro, solteiro, oficial de justiça, RG 23.417.436-5, CPF 143.760.378-50, residente à Rua Boaventura Rodrigues da Silva, 735, Parque Boturussu, São Paulo/SP, CEP 03801-120, venho respeitosamente apresentar a Vossa Excelência o projeto de pesquisa relativo à coleta de dados para a produção de dissertação de mestrado pela Universidade de São Paulo junto aos cartórios das Varas Especiais da Infância e da Juventude da Comarca de São Paulo.

\section{DO REQUERENTE}

Sou titular de cargo de Oficial de Justiça há 12 anos, lotado no Egrégio Tribunal de Justiça do Estado de São Paulo sob matrícula $\mathrm{n}^{\mathrm{o}}$ 352.252-4 (doc. 01), exercendo minhas funções na $10^{\mathrm{a}}$ Vara Cível Central, sito à Praça João Mendes, $\mathrm{s} / \mathrm{n}^{\mathrm{o}}, 7^{\circ}$ andar, desde 14 de abril de 2000, já tendo cumulado funções no Centro Unificado de Cartas Precatórias Cíveis, de Família e Sucessões e de Acidentes do Trabalho, bem como na $1^{\text {a }}$ Vara de Falências e de Recuperações Judiciais. 
Minha formação acadêmica inclui as graduações em Direito e em Psicologia (doc. 02 e 03). Atualmente sou aluno regularmente matriculado no Programa de Pós-Graduação da Escola de Enfermagem da Universidade de São Paulo (doc. 04) e sob a orientação da Professora Doutora Márcia Aparecida Ferreira de Oliveira (doc. 05) venho desenvolvendo o projeto de pesquisa (doc. 06) para a elaboração de dissertação de mestrado envolvendo o estudo da atuação do Poder Judiciário no âmbito da saúde mental.

\section{DO PROJETO DE PESQUISA}

O projeto de pesquisa propõe uma análise da atuação do Poder Judiciário no campo da saúde mental quanto ao modelo assistencial adotado no caso concreto, mediante a realização de pesquisa documental no acervo dos processos judiciais das Varas Especiais da Infância e da Juventude da Comarca de São Paulo - Fórum Brás, sito à Rua Piratininga, 105, Brás, CEP 03042-000, que contenham decisões determinando o encaminhamento de crianças e adolescentes usuários de substâncias psicoativas para tratamento no campo da saúde mental.

A atuação do Poder Judiciário no campo da saúde mental merece atenção em função do processo de transformação que as teorias e as técnicas assistenciais em saúde mental vêm sofrendo nas últimas décadas. Inscrito num contexto histórico-político internacional de reivindicações em favor da humanização do cuidado em saúde mental e de inclusão de modelos assistenciais alternativos, esse processo de transformação conceitual e assistencial em saúde mental no Brasil é representado pelo movimento de reforma psiquiátrica, que se expressa formalmente pela Política Nacional de Saúde Mental $^{38}$ e pela instituição da lei $10.216 / 2001^{39}$ no ordenamento jurídico vigente.

A Política Nacional de Saúde Mental visa à consolidação de um modelo de atenção em saúde mental de base comunitária como substituto do modelo hospitalar especializado e se apoia na lei 10.216/2001. Este diploma legal, conhecido como Lei da Reforma Psiquiátrica, caracteriza-se

\footnotetext{
${ }^{38}$ Conferência Regional de Reforma dos Serviços de Saúde Mental .

${ }^{39}$ Lei 10.216/2001 dispõe sobre a proteção e os direitos das pessoas portadoras de transtornos mentais e redireciona o modelo assistencial em saúde mental.
} 
principalmente por assegurar os direitos das pessoas com transtornos mentais sem qualquer forma de discriminação e reorienta o modelo de assistência em saúde mental.

A questão de propor um estudo sobre a atuação do Poder Judiciário no campo da saúde mental no contexto das transformações teóricotécnicas neste campo adquire maior relevância social diante das políticas públicas propostas pelos poderes públicos em face de crianças e adolescentes usuários de substâncias psicoativas, condição que os tem remetido ao campo da saúde mental.

\section{DO SEGREDO DE JUSTIÇA}

Por força do disposto na Constituição Federal (art. $5^{\circ}$, inciso $\mathrm{LX}^{40}$ ), no Estatuto da Criança e do Adolescente (art. $143^{41}$ ) e no Código de Processo Civil (art. 155 ${ }^{42}$ ), os processos judiciais do Juízo da Infância e da Juventude correm em segredo de justiça.

Com efeito, a realização de pesquisa documental no acervo de processos judiciais das Varas Especiais da Infância e da Juventude da Comarca de São Paulo depende de prévia autorização do Excelentíssimo Senhor Doutor Juiz de Direito das Varas Especiais da Infância e Juventude do Estado de São Paulo.

\section{DO COMPROMISSO ÉTICO}

Comprometo-me a respeitar e seguir rigorosamente as diretrizes da Resolução do Conselho Nacional de Saúde de nº 196, de 10 de outubro de 1996, que dispõe sobre as normas regulamentadoras de pesquisas envolvendo seres humanos.

\footnotetext{
40“A lei só poderá restringir a publicidade dos atos processuais quando a defesa da intimidade ou o interesse social o exigirem".

${ }^{41}$ "E vedada a divulgação de atos judiciais, policiais e administrativos que digam respeito a crianças e adolescentes a que se atribua autoria de ato infracional".

${ }^{42 ، " O s ~ a t o s ~ p r o c e s s u a i s ~ s a ̃ o ~ p u ́ b l i c o s . ~ C o r r e m, ~ t o d a v i a ~ e m ~ s e g r e d o ~ d e ~ j u s t i c ̧ a ~ o s ~ p r o c e s s o s: ~ I-~ e m ~ q u e ~ o ~}$ exigir o interesse público; II - que dizem respeito a casamento, filiação, separação dos cônjuges, conversão desta em divórcio, alimentos e guarda de menores".
} 
Comprometo-me a executar pessoalmente e exclusivamente o previsto no projeto de pesquisa dentro do prazo estipulado.

Comprometo-me, durante o trabalho de campo, a estar sempre de posse da autorização de pesquisa e exibi-la aos magistrados e servidores sempre que solicitado.

Comprometo-me a preservar o segredo de justiça e o sigilo dos dados mediante a adoção de planilha de coleta de dados (doc. 07) que despreza quaisquer informações que possam levar à identificação do processo e das respectivas pessoas nele envolvidas, como as crianças, os adolescentes e seus familiares; os magistrados; os membros do Ministério Público; os advogados; os serventuários da Justiça; os conselheiros tutelares; os policiais; os profissionais de saúde e de assistência social; os educadores; e demais pessoas que eventualmente participem do processo.

Para maiores esclarecimentos informo o contato com o Comitê de Ética em Pesquisa da Escola de Enfermagem da Universidade de São Paulo, a saber, Fone: 11-30617548 e e-mail: edipesq@usp.br.

\section{DAS REFERÊNCIAS}

Magistrados com os quais trabalhei e trabalho que podem dar referências sobre minha conduta profissional e idoneidade moral:

- Dr. José da Ponte Neto, Juiz de Direito Titular da $10^{\mathrm{a}}$ Vara Cível, Central, Fórum João Mendes, $7^{\circ}$ andar, sala 719, fone: 2171-6112;

- Dr. José Joaquim dos Santos, Desembargador da 2a Câmara de Direito Privado, Gabinete 1903, fone: 3295-5161;

- Dr. Alexandre Alves Lazzarini, Juiz de Direito da 6 a Câmara de Direito Privado, Gabinete 1008, fone: 3295-5000. 


\section{DO PEDIDO}

Diante do exposto, solicito respeitosamente a Vossa Excelência autorização para desenvolver atividades de pesquisa no acervo dos processos judiciais das Varas Especiais da Infância e da Juventude da Comarca de São Paulo instaurados no ano de 2011 e no ano de 2012 (até o momento da coleta de dados) que contenham decisões determinando o encaminhamento de crianças e adolescentes usuários de substâncias psicoativas para tratamento no campo da saúde mental pelo prazo de sessenta (60) dias da minha ciência do r. despacho, reiterando meu compromisso de preservar o segredo de justiça.

Termos em que peço deferimento.

São Paulo, 12 de abril de 2012

Ricardo Henrique Soares 
APÊNDICE G

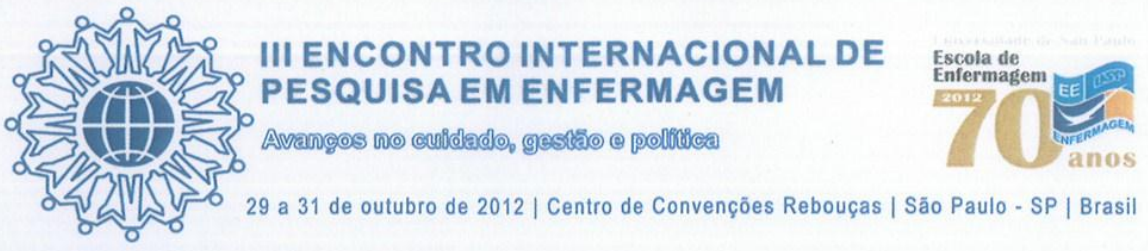

OF.ENP065/12

São Paulo, 22 de maio de 2012.

À Sua Excelência

Sr. Dr. Egberto de Almeida Penido

Juiz de Direito Titular da 1. ${ }^{\text {a }}$ Vara Especial da

Infância e da Juventude da Comarca de São Paulo

Meritíssimo Juiz

Márcia Aparecida Ferreira dé Oliveira, Professora Associada - Livre Docente do Departamento de Enfermagem Materno-Infantil e Psiquiátrica da Escola de Enfermagem da Universidade de São Paulo, RG 11.846.563-6/SP, CPF 053.132.238-60, por meio do presente, venho respeitosamente à presença de Vossa Excelência solicitar os bons préstimos no sentido de autorizar o aluno Ricardo Henrique Soares, RG 23.417.436-5/SP, CPF/MF 143.760.378-50, devidamente matriculado sob minha orientaçäo no Programa de Pós-Graduação desta Escola de Enfermagem, a realizar coleta de dados para a produção de dissertação de mestrado no acervo dos processos judiciais do Primeiro Ofício Especial da Infância e da Juventude da Comarca de São Paulo instaurados no corrente ano de 2012 até o mês de maio, que contenham decisões determinando o encaminhamento de crianças e adolescentes usuários de substâncias psicoativas para tratamento no campo da saúde mental.

Gostaria de consignar o compromisso assumido pelo aluno de preservar o segredo de justiça, tratando os dados a serem coletados com a seriedade e a cautela necessárias a resguardar o sigilo das informações.

Respeitosamente

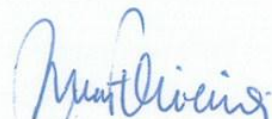

Márcia Aparecida Ferreira de Oliveira 


\section{ENCONTRO INTERNACIONAL DE} PESQUISA EM ENFERMAGEM

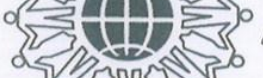

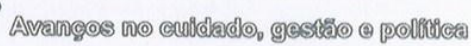

a 31 de outubro de 2012 | Centro de Convenções Rebouças | São Paulo - SP | Brasil

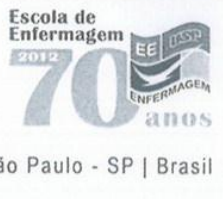

OF.ENP065/12

São Paulo, 22 de maio de 2012.

À Sua Excelência

Sr. Dr. Egberto de Almeida Penido

Juiz de Direito Titular da $1 .^{\text {a }}$ Vara Especial da

Infância e da Juventude da Comarca de São Paulo

$$
\text { Autonjo a pooguise solutele; }
$$

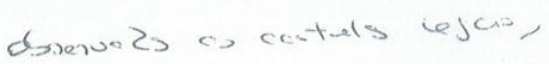

Meritíssimo Juiz
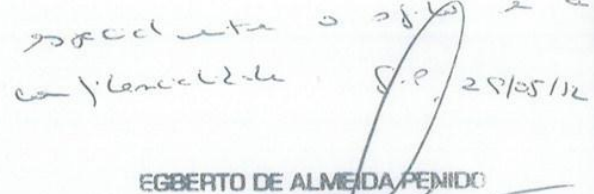

EGBEPTO DE ALMEDDAPENIDO Juiz de Diferto

Márcia Aparecida Ferreira de Oliveira, Professora Associada - Livre Docente do Departamento de Enfermagem Materno-Infantil e Psiquiátrica da Escola de Enfermagem da Universidade de São Paulo, RG 11.846.563-6/SP, CPF 053.132.238-60, por meio do presente, venho respeitosamente à presença de Vossa Excelência solicitar os bons préstimos no sentido de autorizar o aluno Ricardo Henrique Soares, RG 23.417.436-5/SP, CPF/MF 143.760.378-50, devidamente matriculado sob minha orientação no Programa de Pós-Graduação desta Escola de Enfermagem, a realizar coleta de dados para a produção de dissertação de mestrado no acervo dos processos judiciais do Primeiro Ofício Especial da Infância e da Juventude da Comarca de São Paulo instaurados no corrente ano de 2012 até o mês de maio, que contenham decisöes determinando o encaminhamento de crianças e adolescentes usuários de substâncias psicoativas para tratamento no campo da saúde mental.

Gostaria de consignar o compromisso assumido pelo aluno de preservar o segredo de justiça, tratando os dados a serem coletados com a seriedade e a cautela necessárias a resguardar o' sigilo das informações.

Respeitosamente

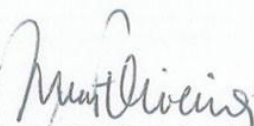

Márcia Aparecida Ferreira de Oliveira 
ANEXO B

\section{ESCOLA DE ENFERMAGEM DA UNIVERSIDADE DE SÃO PAULO - EEUSP}

\section{PARECER CONSUBSTANCIADO DO CEP}

\section{DADOS DO PROJETO DE PESQUISA}

Título da Pesquisa: Atuação do Poder Judiciário no Campo da Saúde Mental

Pesquisador: Márcia Aparecida Ferreira de Oliveira

Área Temática:

Versão: 1

CAAE: 06762112.7 .0000 .5392

Instituição Proponente: Escola de Enfermagem da Universidade de São Paulo - EEUSP

\section{DADOS DO PARECER}

Número do Parecer: 140.063

Data da Relatoria: 13/11/2012

\section{Apresentação do Projeto:}

O projeto de pesquisa propõe uma análise da atuação do Poder Judiciário no campo da saúde mental quanto ao modelo assistencial adotado no caso concreto, mediante a realização de pesquisa documental no acervo dos processos judiciais das Varas Especiais da Infância e da Juventude da Comarca de São Paulo, que contenham decisões determinando o encaminhamento de crianças e adolescentes usuários de substâncias psicoativas para tratamento no campo da saúde mental.

\section{Objetivo da Pesquisa:}

Objetivo geral: Conhecer, compreender e analisar os discursos que sustentam a atuação do Poder Judiciário da Comarca de São Paulo no campo da saúde mental quanto ao modelo assistencial adotado no caso concreto.

Objetivos específicos:

- Caracterizar e analisar os autos dos processos judiciais das Varas Especiais da Infância e da Juventude que contenham decisões determinando o encaminhamento de crianças e adolescentes usuários de substâncias psicoativas para tratamento no campo da saúde mental quanto ao modelo assistencial adotado no caso concreto

- Descrever e discutir o perfil sócio-econômico das crianças e dos adolescentes usuários de substâncias psicoativas que são submetidas pelas Varas Especiais da Infância e da Juventude a tratamentos no campo da saúde mental.

- Apreender e discutir as idéias, significados e representações contidas nos discursos judiciais das

Endereço: Av. Dr Enéas de Carvalho Aguiar, 419

Bairro: Cerqueira Cesar

CEP: $05.403-000$

UF: SP Município:

Telefone: (113)061--7548

Fax: (113)061--7548

E-mail: edipesq@usp.br; celiasiv@usp.br 


\section{ESCOLA DE ENFERMAGEM DA UNIVERSIDADE DE SÃO PAULO - EEUSP}

Varas Especiais da Infância e da Juventude que sustentam as decisões que determinam o tratamento de crianças e adolescentes usuários de substâncias psicoativas no campo da saúde mental

\section{Avaliação dos Riscos e Benefícios:}

Não há riscos pois se trata de uma análise documental.

Benefícios apresentados no estudo: revelar tendências das decisões do Poder Judiciário e alinhamento tecnológico em saúde mental; conhecer a qualidade de atuação no processo da reforma psiquiátrica, examinando o nível de apropriação dos referenciais e princípios da reforma psiquiátrica brasileira.

\section{Comentários e Considerações sobre a Pesquisa:}

O estudo tem por hipótese: As decisões do Poder Judiciário no campo da saúde mental estão orientadas para o modelo de assistência psiquiátrica tradicional ou para o modelo de assistência proposto pela reforma psiquiátrica? Abordará qualitativamente os dados colhidos na pesquisa sob o referencial teórico do materialismo dialético e histórico, utilizando a análise de discurso como estratégia de análise documental. Se propõe a rever 2000 processos judiciais.

\section{Considerações sobre os Termos de apresentação obrigatória:}

O estudo dispensa o TCLE pois trata-se de uma pesquisa documental. No entanto, necessitará de autorização judicial para análise dos processo da Vara Especial da Infância e da Juventude. Foi apresentada carta solicitando ao juiz responsável pela Vara autorização para utilização dos processos como fonte de dados para a pesquisa.

\section{Recomendações:}

Não há.

Conclusões ou Pendências e Lista de Inadequações:

O projeto está aprovado do ponto de vista ético.

\section{Situação do Parecer:}

Aprovado

\section{Necessita Apreciação da CONEP:}

Não

\section{Considerações Finais a critério do CEP:}

O colegiado reitera a aprovação do projeto. 


\section{ESCOLA DE ENFERMAGEM DA UNIVERSIDADE DE SÃO PAULO - EEUSP}

07 de Novembro de 2012

Assinador por:

Celia Maria Sivalli Campos

(Coordenador) 